Florida International University FIU Digital Commons

\title{
Museum of urban development and headquarters for the planning/preservation department of the city of Miami Beach.
}

Roberto Bezold

Florida International University

DOI: $10.25148 /$ etd.FI14051138

Follow this and additional works at: https://digitalcommons.fiu.edu/etd

Part of the Architecture Commons

\section{Recommended Citation}

Bezold, Roberto, "Museum of urban development and headquarters for the planning/preservation department of the city of Miami Beach." (2001). FIU Electronic Theses and Dissertations. 1606.

https://digitalcommons.fiu.edu/etd/1606 
FLORIDA INTERNATIONAL UNIVERSITY

Miami, Florida

MUSEUM OF URBAN DEVELOPMENT AND HEADQUARTERS FOR THE PLANNING/PRESERVATION

DEPARTMENT OF THE CITY OF MIAMI BEACH

A thesis submitted in partial fulfillment of the

requirements for the degree of

MASTER OF ARCHITECTURE

by

Roberto Bezold

2001 
This thesis written by Roberto Bezold, and entitled Museum of Urban Development and Headquarters for the Planning/Preservation Department of the City of Miami Beach, having been approved in respect to style and intellectual content, is referred to you for judgment.

We have read this thesis and recommend that it be approved.

Kevin Smith

Raul Garcia

Marilys R. Nepomechie, Major Professor

Date of Defense: April 6, 2001

The thesis of Roberto Bezold is approved.

Dean William McMinn

School of Architecture

Interim Dean Samuel S. Shapiro Division of Graduate Studies

Florida International University, 2001 
DEDICATION

I dedicate this thesis to my family: Leticia, Lula, Luigi, Willy and Clayde Without their patience, understanding,

support, and most of all love, the completion of this work would not have been possible.

To Leticia, mi espocita, thanks for all the love, and more love.

To Luigi, mi hermano, thanks for all the help and love, especially for the help during the toughest times.

To Lulica, mi mami, thanks for all the unconditional love since 1973.

To Willy, mi pacho, thanks for everything, including all the help as an outstanding architecture consultant. 


\section{AKNOWLEDGMENTS}

I want to thank the members of my committee and all FIU faculty members for the support during the period that I studied at the School of Architecture. To Ms. Marilys Nepomechie, my Major Advisor, I thank for all the good ideas in design, the patience and unlimited help and availability for all my questions. To Mr. Kevin Smith, I am very thankful for all the help and advise in design as well as for all the technical advising and good humor. To Mr. Raul Garcia, thanks for all the help in the design analysis, useful information and knowledge in the Preservation field as for his invaluable friendship and collaboration with books, research documents and other useful material. To Mr. John Stuart, thanks for been an outstanding Graduate Advisor and professor who help me start with my thesis during Pre-thesis seminar. To all you, Marilys, John, Kevin and Raul my sincere gratitude for been my professors and friends during all the time I studied at FIU. 
MUSEUM OF URBAN DEVELOPMENT AND HEADQUARTERS FOR THE PLANNING/PRESERVATION

\section{DEPARTMENT OF THE CITY MIAMI BEACH}

by

Roberto Bezold

Florida International University, 2001

Miami, Florida

Professor Marilys R. Nepomechie, Major Professor

The objective of this research and thesis was to develop a program and project in the context of the Historic Art Deco District in Miami Beach. This project intended to analyze the chronological history of the urban development of the Art Deco District, its geographical, political and socio-cultural conditions as well as the evolution and different architectonic typologies of the area. In order to understand the issues involved in design in a historic context, this research addressed and analyzed several architectonic interventions within various historic places. This research concluded with the design of a public facility located at Ocean Drive, Miami Beach, consisting of a Museum of Urban Development and Headquarters for the Planning/Preservation Department of the City of Miami Beach. The project proposal and thesis addresses architectonic and theoretical issues specific to design in an historic area. 


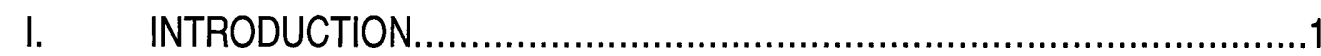

II. HISTORICAL BACKGROUND .............................................................

The Boom Years, 1920s-1930s.

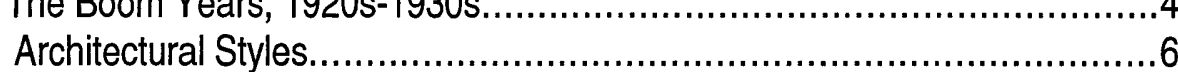

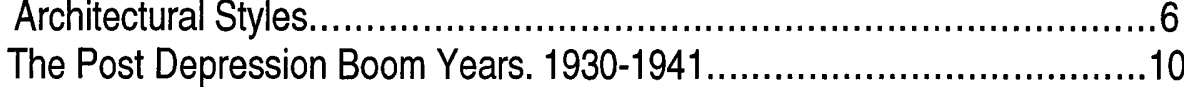

The War Years, 1942-1945............................................. 16

The Post War Boom, 1945-1965 .....................................................17

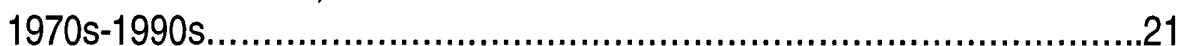

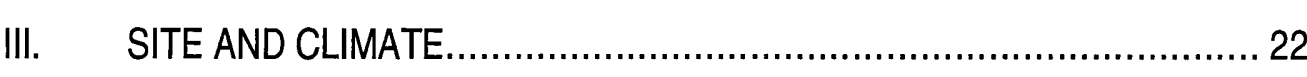

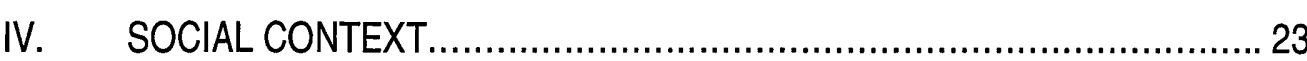

V. PRESERVATIONISTS VS. INVESTORS..........................................23

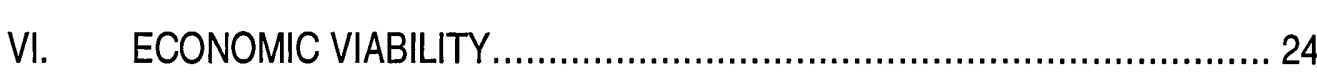

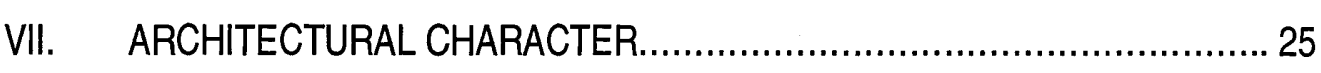

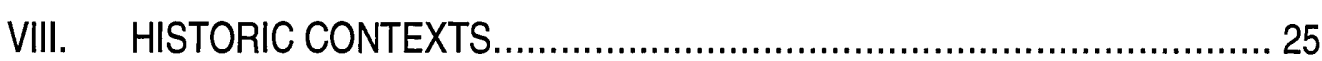

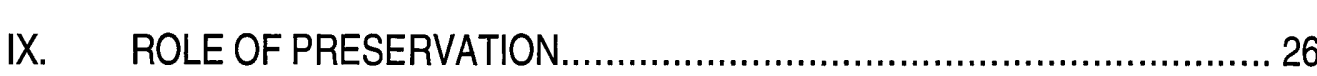

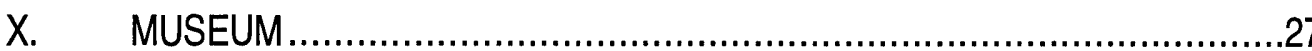

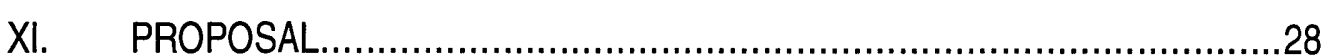

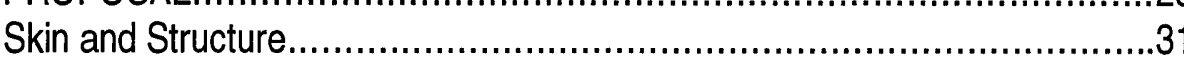

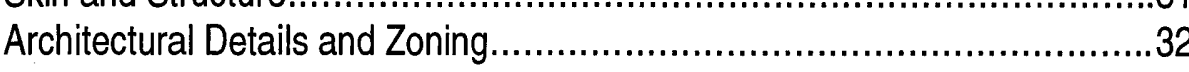

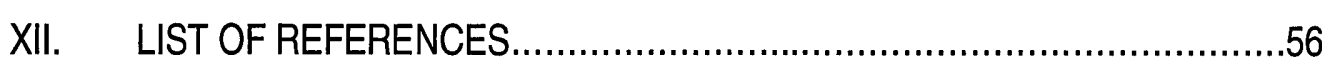


21. The Tides Hotel, 1220 Ocean Dr.

1. Map of Miami Beach.

....3

2. Map of Architectural District...............................................................

3. Miami Beach Early Coconut Plantation.................................................2

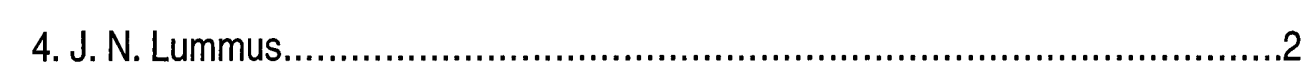

5. Collins Bridge Openning Day on June 12, 1913.......................................

6. Miami Beach Early Roads, Atlantic Boulevard..........................................

7. Miami Beach Aerial View During the 1920 s................................................5

8. The Martha Hills Apartments, 850 Ocean Dr.............................................

9. Casa Grande, 834 Ocean Dr...............................................................

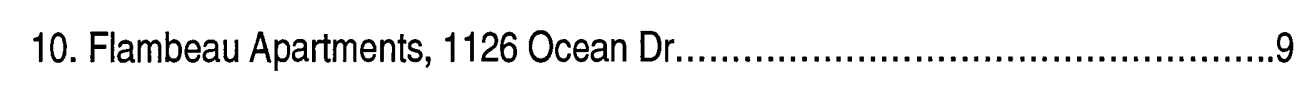

11.Ocean Drive Hotel, 760 Ocean Dr........................................................11

12. Park Hotel, 928 Ocean Dr.................................................................11

13. Locust Apartments, 918 Ocean Dr.........................................................11

14. Beach Paradise Hotel, 600 Ocean Dr.................................................11

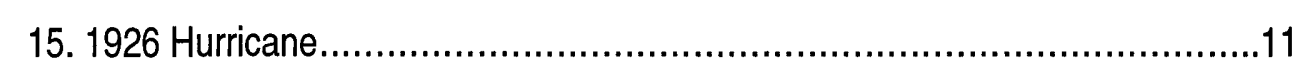

16. The Post Depression Boom Years, 1930-1941 .........................................11

17. The Amsterdam Palace, 1116 Ocean Dr..............................................13

18. Edison Hotel, 960 Ocean Dr...........................................................13

19. The Netherland Hotel, 1330 Ocean Dr...............................................13

20. Irene Marie Apartments, 728 Ocean Dr.............................................13

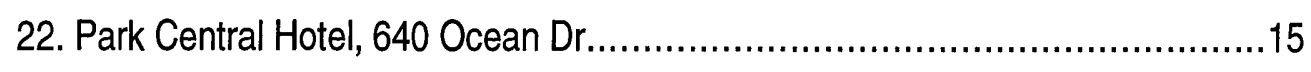

23. The Waldorf Tower, 860 Ocean Dr ..................................................15

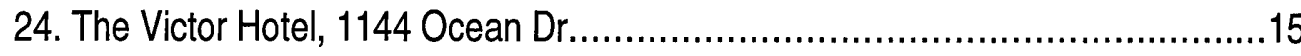

25. The Clevelander Hotel, 1020 Ocean Dr.................................................15

26. The Breakwater Hotel, 940 Ocean Dr...................................................15

27. The Winter Haven , 1400 Ocean Dr........................................................15

28. The Cardozo Hotel, 1300 Ocean Dr....................................................16

29. The Avalon Hotel, 700 Ocean Dr....................................................16

30. The Ocean Plaza, 1430 Ocean Dr............................................................16

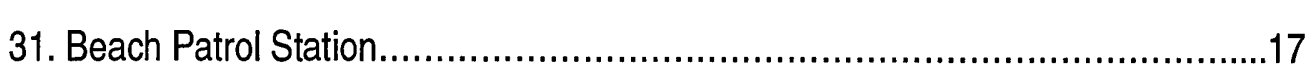

32. Oceanfront Auditorium, 1001 Ocean Dr.................................................17

33. The War Years, 1942-1945 ............................................................17

34. The Pelican Hotel, 826 Ocean Dr....................................................19

35. The Boulevard, 740 Ocean Dr.........................................................19

36. The Adrian Apartments, 1052 Ocean Dr................................................19

37. The Eastern Sun Apartments, 900 Ocean Dr.............................................19

38. The Ocean Park Apartments, 1412 Ocean Dr............................................19

39. The Sun Haven Apartments, 800 Ocean Dr..............................................20

40.The Casa Grande Suite Hotel, 834 Ocean Dr.............................................20

41. The White House Apartments, 1446 Ocean Dr..............................................20

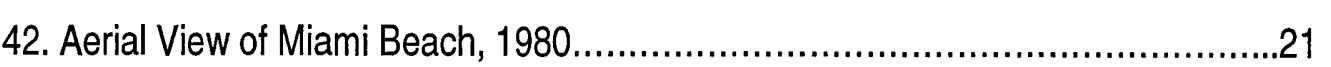


43. The Ocean Promenade, 1040 Ocean Dr

44. II Villagio Condominium, 1455 Ocean Dr. .22

46. 1500 Ocean Drive

47. Soldiers Trainning at Miami Beach

48. Barbara Capitman $\ldots 24$

49. Site for Project Proposal. $\ldots .27$

50. Perspective - !st Level of Museum Proposal $\ldots .28$

51. Pedestrial Walkway . .29

52. $4^{\text {th }}$ Level Plan View of Museum Proposal. ...30

53. Perspective view of Digital Screen on Main Façade of Museum Proposal.......31

54. Rendering Image of Scaffolding Structure of Museum Proposal...................32

55. Entrance Level Floor Planof Museum Proposal........................................33

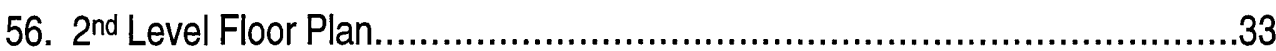

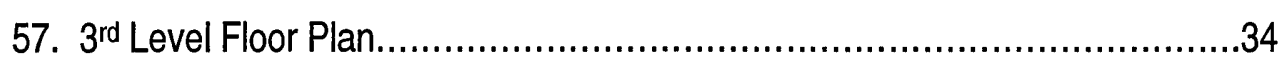

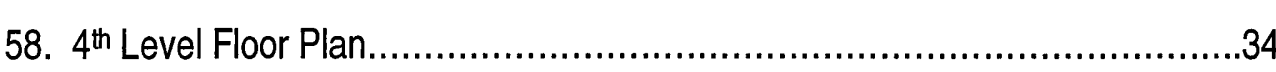

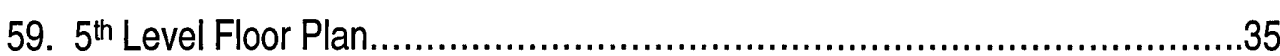

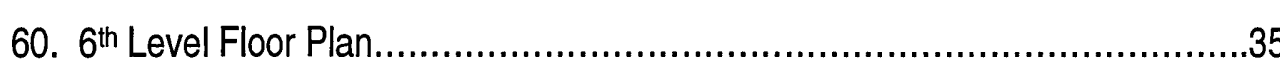

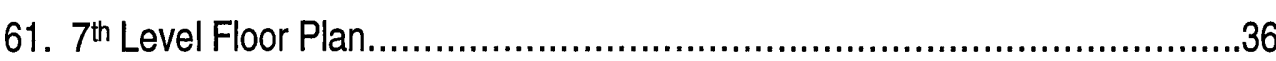

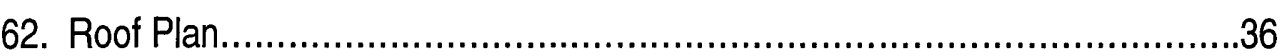

63. Main Façade, East Elevation.........................................................37

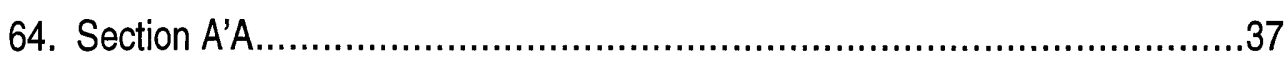

65. Entrance Level Isometric View....................................................38

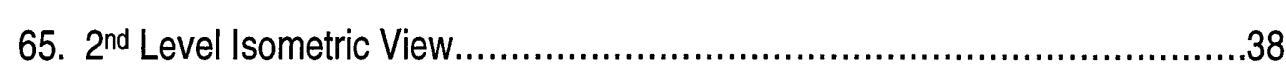

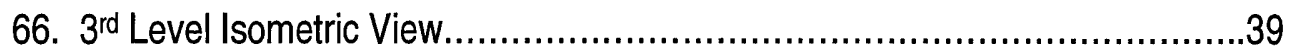

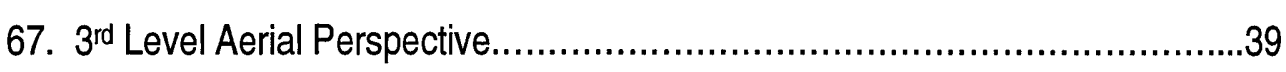

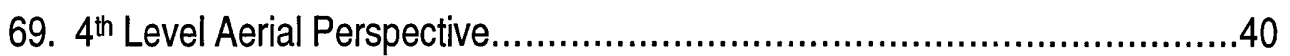

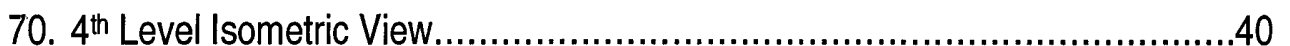

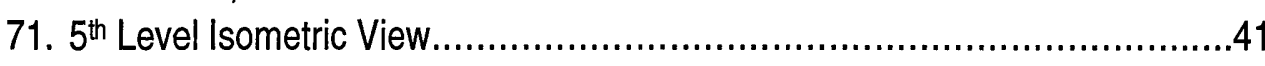

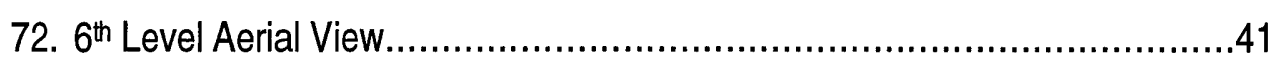

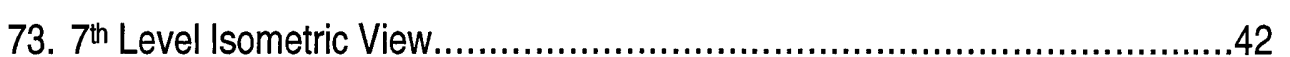

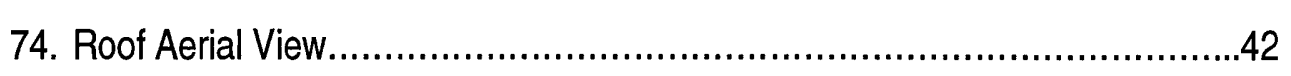

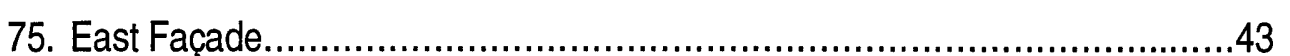

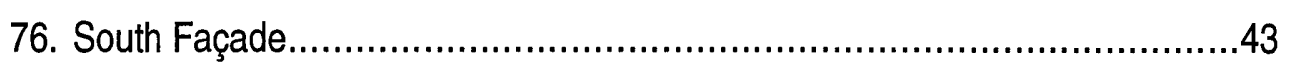

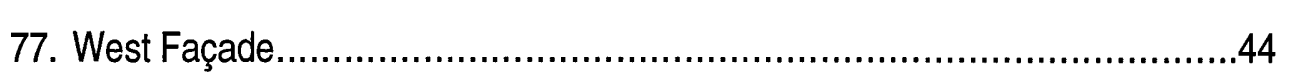

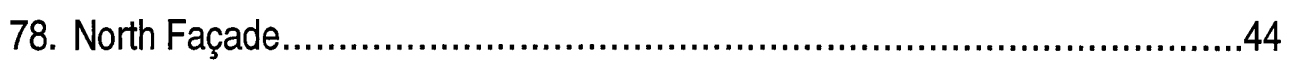

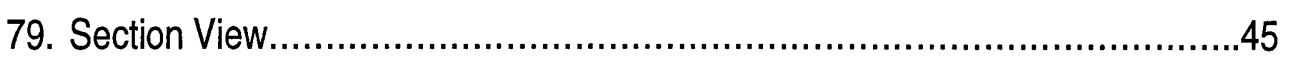

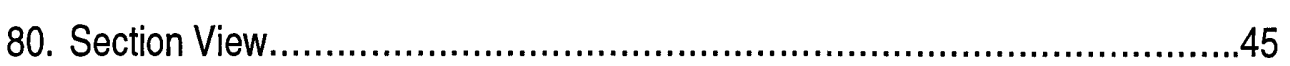

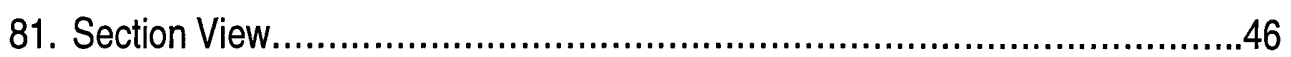

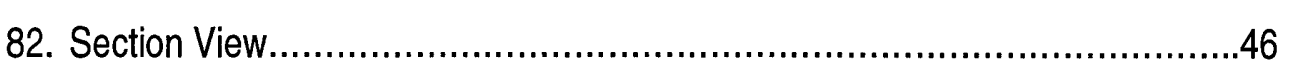

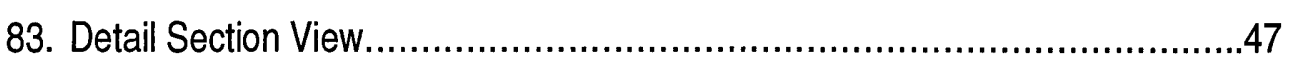

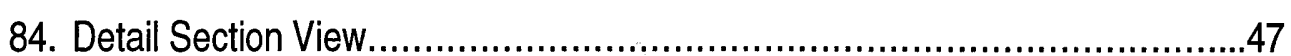

85. East Façade Detail Perspective........................................................48

86. Interior Walkway and Exhibition Detail Perspective...................................48

87. Interior Walkway and Exhibition Detail Perspective (East-West)....................49 
188. Interior Walkway and Exhibition Detail Perspective (West-East)

88. Camera View of Ocean Drive from the Ocean Perspective..........................52

89. Interior Perspective from Auditorium.......................................................53

90. Night View of Terrace of Museum Proposal..............................................53

91. Aerials -View and Model...............................................................54

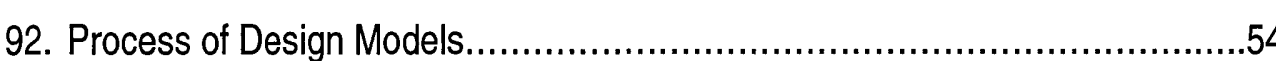

93. Final Model Perspective Views.............................................................55

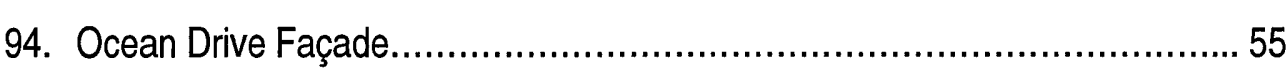




\section{Introduction}

Ocean Drive lies at the heart of the Historic Art Deco District in Miami Beach'1. It is one of the most historically significant avenues on Miami Beach, which is bounded on the west by the Biscayne Bay, on the east by the Atlantic Ocean, on the north by the city of Surfside and on the south by Government Cut. Miami Beach is composed of more than 5,000 acres and 16 islands located in South Florida. (Figure 1) The largest of the islands is seven miles long and one-and-a-half miles wide. Within this island lies the Art Deco Historic District.

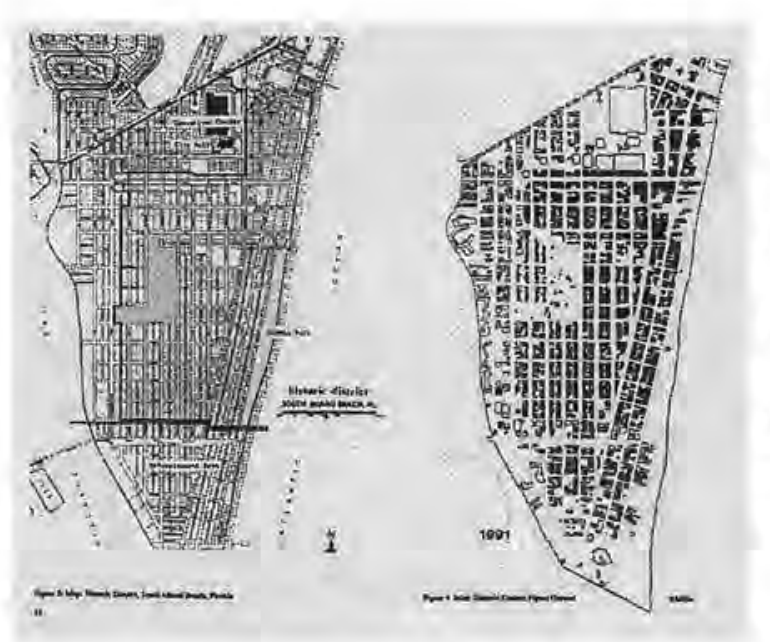

Designated in 1979 as the Architectural District, (Figure2) the Historic Art Deco District is composed of more than 800 buildings listed in the National Register of Historic Places. It is one of the largest districts listed in the National Register and one of the youngest, in terms of the age of its buildings, which were mostly built between 1923 and 19432. The Art Deco District roughly forms a rectangle within Miami Beach, bounded by the Atlantic Ocean on the east, Alton Road on the west, $6^{\text {th }}$ street on the south and Dade Boulevard along the Collins canal to the north. ${ }^{3}$ Most historic buildings stand along four major urban arteries: Collins Avenue, Lincoln Road, Ocean Drive and Washington Avenue.

Ocean Drive is a north-south boulevard running parallel and next to the Atlantic Ocean along south Miami Beach. Sixtynine buildings are located along Ocean Drive. These represent a great amount of history of the Art Deco Historic District and the City of Miami Beach. The first architectonic and urban developments in Miami Beach occurred in this area. The first home in the city of Miami Beach, for example, was built where the Tides Hotel now stands on Ocean

${ }_{2}^{1}$ Victor Diaz. Historic Preservation Board. Miami Beach Preservation Board meeting at 08-10-2000.

${ }_{3}^{2}$ Keith Root. MDPL The Art Deco Guide. Miami Design Presenvation League, 1987. p.5

${ }^{3}$ Keith Root. MDPL The Art Deco Guide. Miami Design Preservation League, 1987. p.5
Drive and $12^{\text {th }}$ street. In order to design in a historic context it is fundamental to understand the history and development of the place. This helps in understanding the existing conditions that provide the background for a new proposal.

Architecture in wider use means "unchanging deep structure". ${ }^{4}$ Architecture should in a sense be permanent as part of a continuous process that should not be broken. Architecture, like any human activity evolves with history and every period of development within history is important to the overall outcome and continuous process of evolution. From Vitruvius to $20^{\text {th }}$ century architectural theory, architecture has been defined as an evolutionary process. Robert Venturi and Denise Scott-Brown, Jane Jacobs and James Marston Fitch, founder of preservation as an academic discipline in America, have all written about continuity in architecture. ${ }^{5}$ Peter Eisenman's drawing of an arrow (picture $-\mathrm{N}$. Tyler. Historic Preservation p.14) is a metaphor for the concept that a building does not represent its own time period only, but is also part of a time continuum. ${ }^{6}$ This quote by writer I. L. Peretz about people can also be used for architecture and buildings: "Not only an individual, but a people, too, must possess a memory. A people's memory is called history. What is true of an individual without memory is also true of a people without history: they cannot become wiser or better."7

\section{Historical Background}

To understand the context along Ocean Drive, it is important to study its history as part of the chronological development of the area, spanning from the early developments of southern Florida, near the 1500 s, into present times. The area along Ocean Drive and Miami Beach developed slowly in comparison to other parts of South Florida. During the 1500s, the area surrounding the Art Deco District and Miami Beach was part of a chain of deserted barrier islands with shifting sands on the Oceanside and thick mangroves on the bayside. ${ }^{8}$ Until the 1800 s, Florida belonged primarily to the Spanish and the English. At that time Florida was a land primarily populated with runaway slaves, Native Americans, pirates and rugged pioneers. Unable to control the land, the Spanish ceded it to the United States in 1821. In 1827 Florida became the $27^{\text {th }}$ state of the United States. When Florida became a state, the United States turned over

${ }^{4}$ Stewart Brand. How Buildings Learn. New York: Penguin Books, 1995. p. 2 ${ }^{5}$ Nomes Marston Fitch. Historic Preservation. University of Virginia, 1990. 
the unsettled land for use as a funding source for the new state government. Settlers were encouraged to purchase lands at low costs and to develop their own properties. In 1868, Henry B. Lum, a farmer from Pennsylvania, sailed from Key West to Miami and then over to explore the beach wilderness area on the eastern side of the Biscayne Bay. He saw three palm trees growing on the beach, and they gave him the idea of a coconut plantation. ${ }^{9}$ (Figure 3 )

By 1881, Lum owned all of the land south of today's $14^{\text {th }}$ street. He purchased the land, for 35 cents an acre, from the State of Florida. Other investors followed his steps and bought land to use as coconut farms. John Stiles Collins was one of those investors. In

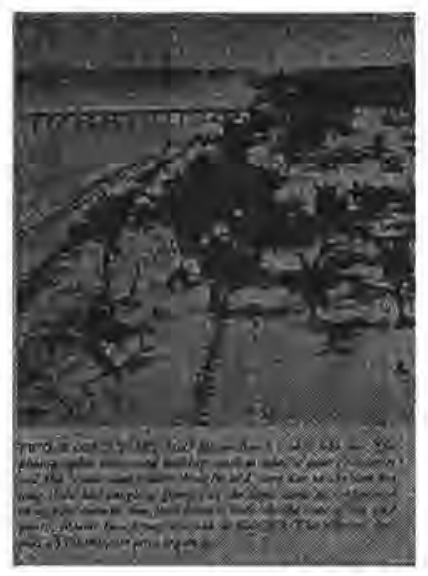
1886, Charles Lum, son of Henry Lum, built a two-story house on the oceanfront, at what is today the Tides Hotel, on Ocean Drive and $12^{\text {th }}$ street. It was the first house built in Miami Beach. By 1890 , the Coconut plantation business went bust mainly because of geographical conditions. The dense mangroves made land preparation very difficult and the sand flies and mosquitoes made working conditions extremely hard.

Because of financial hardship, the Lum family left Miami Beach in 1890.

In 1896, the City of Miami Beach was founded. Some years later, in 1904, Richard M. Smith, a former Connecticut schooner captain and Dade County Tax assessor, inaugurated the first rudimentary ferry service between Miami and the beach, erecting a pavilion near the foot of present day Ocean Drive. The pavilion, an elevated open-air dance hall and bathing house with a steep pyramid roof, was named Smith's Casino. It was the first resort structure in what is now Ocean Beach, and preceded even the completion of Government Cut on March 14, 1905.10 In the summer of 1905, Mayor John Sewell declared a holiday so that everyone could witness the mingling of the "muddy waters of Biscayne Bay" with the "turquoise blue of the Atlantic Ocean".11 Around 1907, brothers John and James Lummus, each president of a different Miami bank, bought 580 acres of bayfront and beachfront land on the southern end of Miami Beach, on the

1. L. Peretz. "On History", in Stories by Peretz, trans. Sol Liptzin.NY: Hebrew Publishing, 1942. p. 202

8 Keith Root. MDPL Thy Art Deco Guide. Miami Design Preservation League, 1987. p.11.
${ }^{9}$ Keith Root. MDPL The Art Deco Guide. Miami Design Preservation Leage, 1987.

${ }^{10}$ City of Miami Beach Planning, Design and Historic Preservation Division. Ocean Beach Historic District Designation Report 1995 p. 11

11 Ava Moore Parks. Magic City, Miami. Miami: Centennial Press, 1991. p. 87 land once occupied by Lum's plantation. The Lummus brothers, recognizing the need for a good beach for the tourists, who were pouring into Miami, built a bathhouse on the beach.

In 1912, the first land sales company was established in Miami Beach. The Ocean Beach Realty Company was responsible for the first plat recorded within the Dade County. J. N. Lummus, founder and first president of the company, (Figure 4) was a man who envisioned a city fronting the ocean made up of modest single-family residences. ${ }^{12}$ This idea was clearly reflected in the platting pattern of 50 by 140 foot lots within 300 by 400 foot blocks, split by a 20 -foot wide right-of-way running down the center of the blocks in a north- south direction ${ }^{13}$. This overall scheme of blocks and streets was oriented parallel to the ocean on today's Ocean Drive. The Lummus brothers were responsible for the first major developments on the area that is now Ocean Drive. According to Miami Beach Planning Department research documents and Miami Design Preservation League archives, the Lummus brothers intended to develop a middle class community resort along the coastline.

In 1913, the Collins Bridge opened, (Figure 5) which connected Miami Beach with the mainland in order to transport goods and people. The bridge was named after John Collins, who was another of the early Miami Beach investors that owned avocado plantations and a five-mile strip of land between $14^{\text {th }}$ street and $67^{\text {th }}$ street, along today's Collins Avenue. The Lummus Brothers and Carl Fisher, a wealthy industrialist, joined John Collins in the construction of the bridge, bringing much needed capital to the project. Carl Fisher, John Collins and the Lummus brothers were the main investors in Miami Beach during the first decades of the 1900's. Carl Fisher developed the area of Lincoln Road and north of Ocean Drive to $41^{\text {st }}$ street. The Lummus brothers however, were entirely responsible for the early development of Ocean Drive.

${ }^{12}$ Michael Raley. Old Miami Beach. Miami Design Preservation League, 1994. p 7 ${ }^{12}$ bid. p. 7 

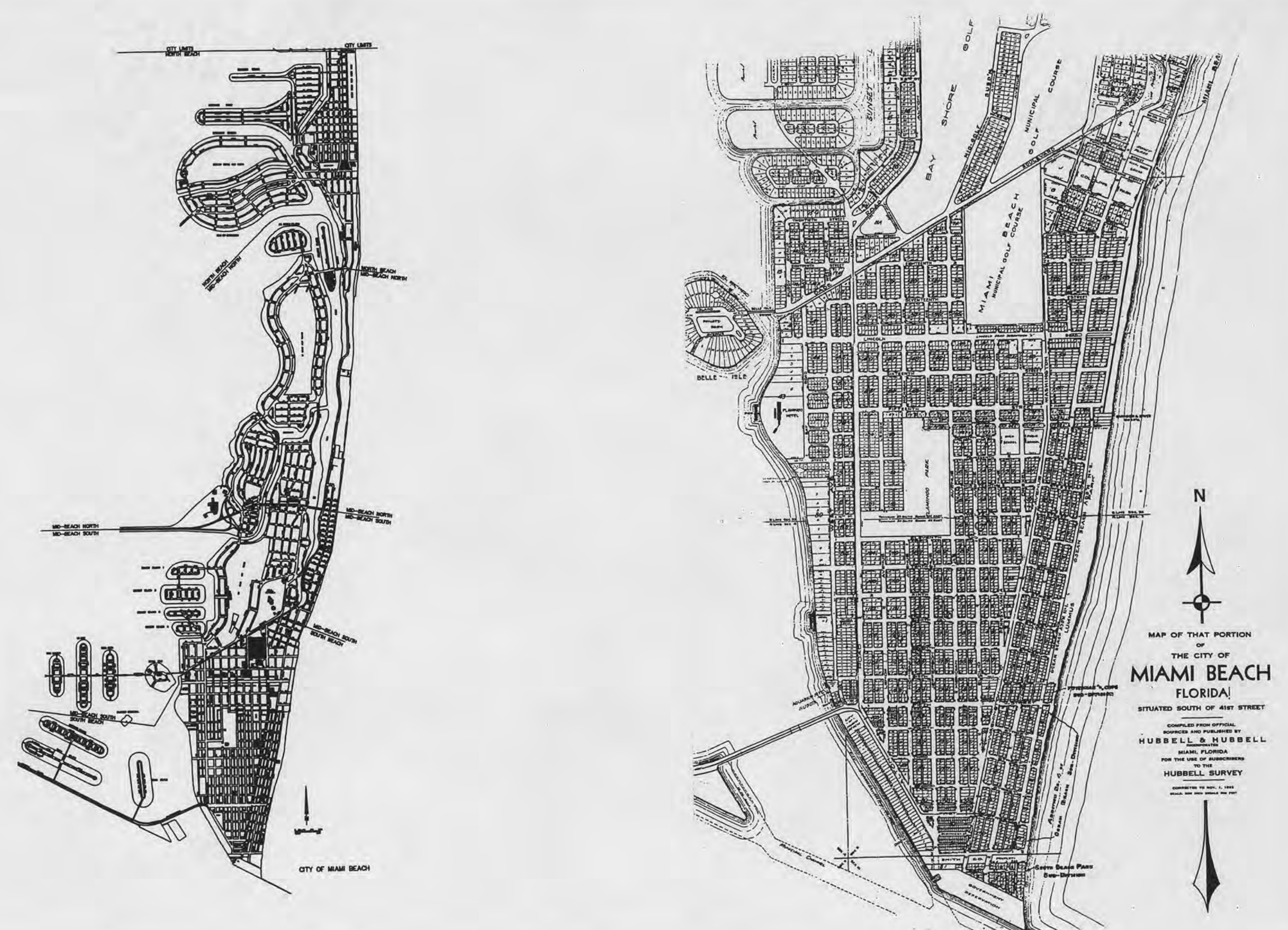
Around 1913, the Lummus' built a road by the sea, called Atlantic Boulevard. It was the first vehicular road, in the location of present day Ocean Drive. (Figure 6) On April 15, of 1915, William H. Brown, a Scottish immigrant and plumber, bought a lot just north of today's 1st street. On that site, first hotel in Miami Beach was built, at 112 Ocean Drive. It was named the Atlantic Beach Hotel but was also known as the Brown's Hotel after its owner. (Figure 6) Today, the building is called Star Apartments. Currently, there is a proposal to restore the building to its original status and to add to the structure, by Miami architect Allan Shulman.

Also in 1915, J. N. Lummus was elected mayor of the City of Miami Beach. As one of his first acts, he changed the name of the oceanfront road to Collins Avenue. In November of that year, he sold about 200 acres of his private land to the City for $\$ 40,000$ with the condition that the city would construct a public park on that property. By having a park in front of his remaining property, it became more valuable..$^{14}$ The Lummus brothers' original plan for the area that is now South Beach was to generate a diverse, middle class resort. The Lummus brothers never intended to build tall buildings or mansions in the area along Ocean Drive. Their vision was always of a conjunction of low scale buildings. ${ }^{15}$ This set the typology for the urban development that occurred along Ocean Drive and the area that is now known as The Art Deco District.

In 1916, the sale of land on Miami Beach was sluggish. Lummus offered free lots to anyone who promised to build homes on his land. Lummus' policies for selling land were far less discriminatory to potential buyers than those of other investors, including Carl Fisher. Lummus gave away 35 home sites in a day in one occasion. His "non-discriminatory" policy for selling his land was to offer property to any buyer who was "white, law-abiding, and could afford the down payment on the property."16 Many of the property owners who purchased land from Lummus were Jewish. Today, in the twenty-first century, the diverse ethnic population in the area originally developed by Lummus, reflects his less

${ }_{15}^{14}$ Keith Root. MDPL The Art Deco Guide. Miami Design Preservation League, 1987. p.7. discriminating policies in comparison with northern areas developed by Fisher. However, in present times, Ocean Drive has become a place for the rich, the wealthy and beautiful.

\section{The Boom Years 1920-1930}

(Figure 7) The urban development of Miami Beach began in the early 1900s. But the 1920's were called 'The Boom years." ${ }^{17}$ By 1921 there were in total five hotels and nine apartment houses on the Beach. Today, eight of the buildings built between 1920-1929 remain on Ocean Drive. These include the 1922 Creighton Court Apartments. Constructed by John $\mathrm{C}$. Williams, this two story residential building contained thirteen apartment units. At about 33 feet high, this $\mathrm{U}$ shaped building is composed of a large patio with steps at the entrance facing the ocean. The Creighton Court Apartments is considered a historic building and represents the early development of Ocean Drive's original small boarding houses. 18

The Historic Preservation Board of Miami Beach considers the site significant and much of its vernacular architectural features, including its exterior envelope made of stucco, still remains intact. ${ }^{19}$ From 1988 to 1990 , there were alterations made to the building. The area changed to mixed-use zoning, and the interior space was modified to host what is today the News Café bookstore. Now the building is called the Ocean News on 804 Ocean Drive.

The term "significance" when referring to a building has been widely used but should follow certain criteria established by the National Register of Historic Places, in the United States. The criteria for the National Register and for most, if not all, local landmark and historic district ordinances specify that properties may be designated on the basis of local significance as well as by virtue of their significance to a state or the nation..$^{20}$

${ }_{18}^{17}$ bid. p. 7

${ }_{18}^{18}$ Buildings are designated as Historic or non-Historic by The City of Miami Beach Planning Department and Historic Preservation Board ${ }^{20}$ Britannica. com. www.sah.org. The Society of Architectural Historian 


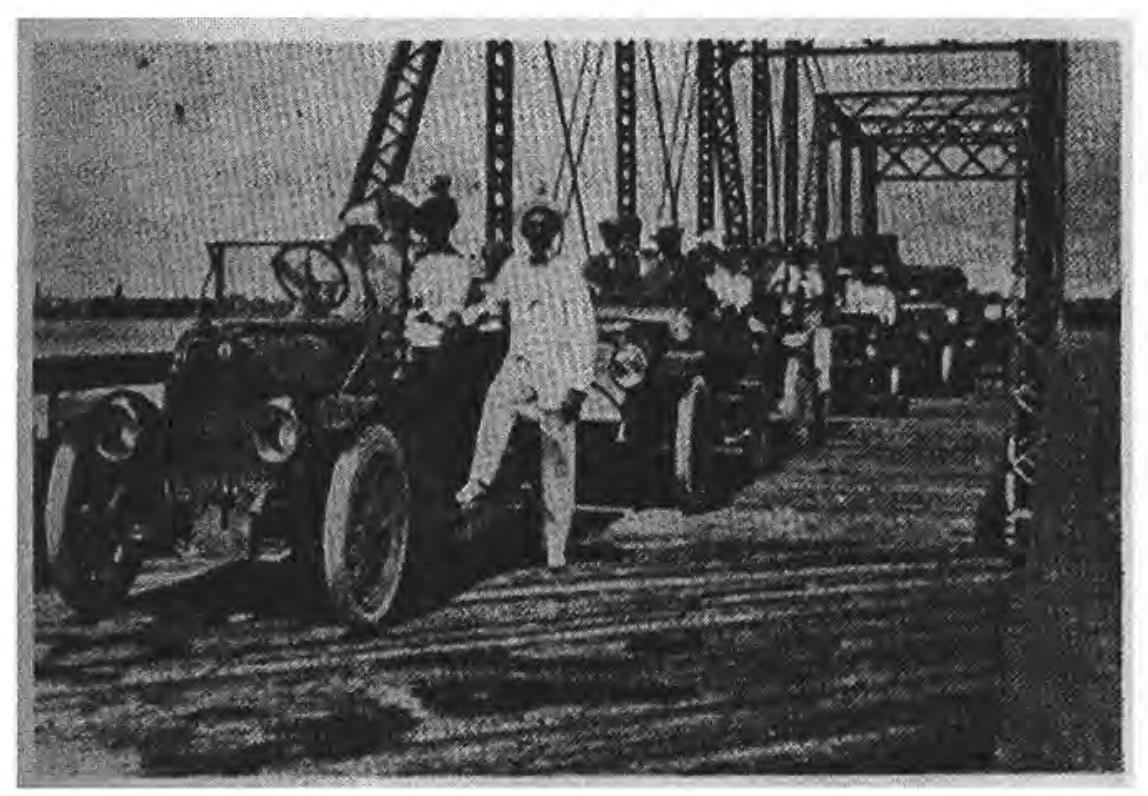

F. 4

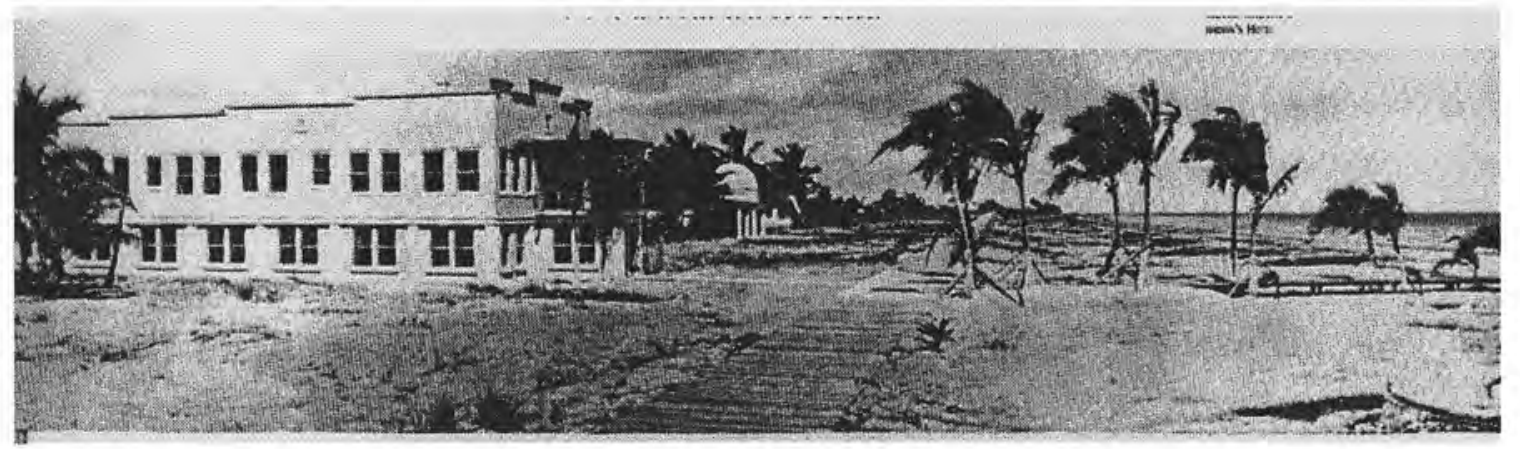

F. 6

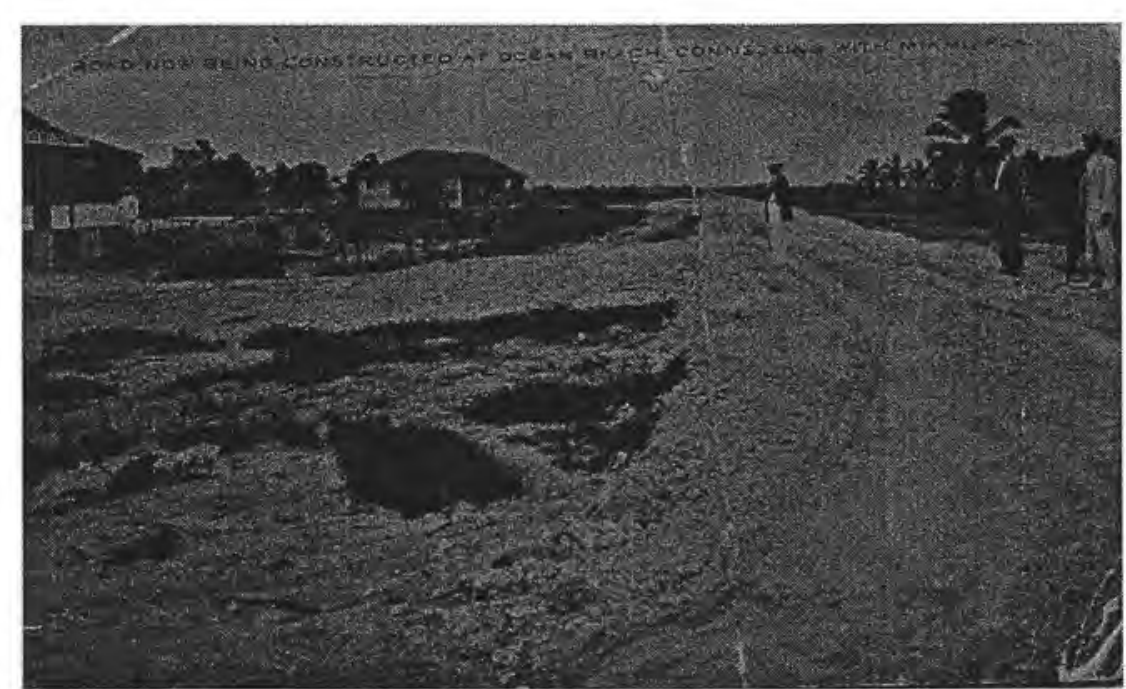

F. 5

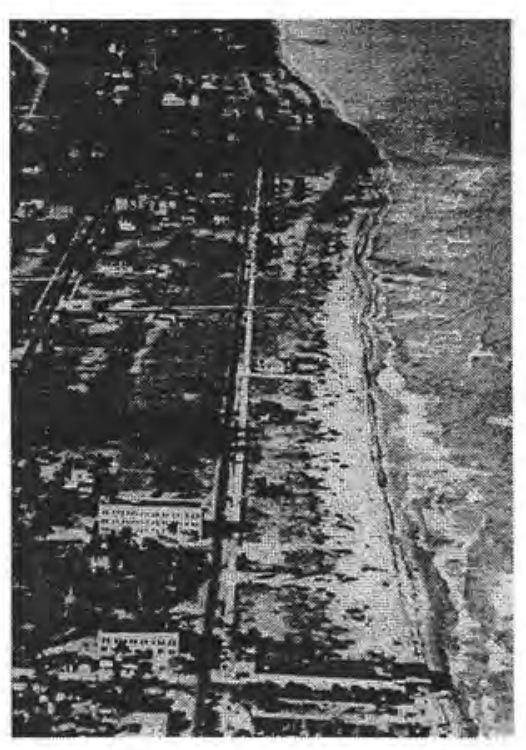

F. 7 
According to the National Register, the quality of significance in American history, architecture, archeology, engineering and culture is present in districts, sites, buildings, structures, and objects that possess integrity of location, design, setting, materials, workmanship, feeling, and association and:

(a) That are associated with the lives of persons significant in our past;

(b) That are associated with the lives of persons significant in our past;

(c) That embody the distinctive characteristics of a type, period, or method of construction, or that represent the work of a master, or that possess high artistic values, or that represent a significant and distinguishable entity whose components may lack individual distinction; or

(d) That has yielded, or may be likely to yield, information important in prehistory or history. ${ }^{21}$

The City of Miami Beach has defined and organized a set of institutions responsible for the preservation and regulations of Miami Beach. The main identities are: the Miami Beach Historic Preservation Board, including a member from the Miami Design Preservation League. Then, there are the Miami Beach Planning Board, the Miami Beach Development, Design and Historic Preservation Services Department, the Planning, Design and Historic Preservation Division and the City Commission. ${ }^{22}$ The Historic Preservation Board of Miami Beach classifies buildings as contributing or noncontributing. A contributing building is defined as any property or building that possesses integrity of location, design, setting, materials, workmanship, feeling or association, and meets at least one of the following criteria:23

(1) Association with events that have made a significant contribution to the history of Miami Beach, the county, state or nation;

(2) Association with the lives of Persons significant in our past o r history;

(3) Embody the distinctive characteristics of an historical period, architectural or design style or method of construction;

(4) Possesses high artistic values;
(5) Represents the work of a master; serves as an outstanding or representative work of a master designer, architect or builder who contributed to our historical, aesthetical or architectural heritage;

(6) Has yielded, or is likely to yield, information important in pre-history or history;

(7) Listed in the National Register of Historic Places;

(8) Consists of a geographically definable area that possesses a significant concentration of Sites, Buildings or Structures united by historically significant past events or aesthetically by plan or physical development, whose components may lack individual distinction.

Most of the contributing, historic buildings on Ocean Drive were constructed during the 1930's and 1940's.

The majority of the buildings constructed during the 1930's favored the Moderne Style of architecture. The architecture on Ocean Drive is considered cohesive and harmonious. The popularly known Art Deco architecture, which includes all the buildings on Ocean Drive, and the Art Deco district, refers to a series of different styles of architecture that developed during the first half of the $20^{\text {th }}$ century.

Vernacular/Early Transitional (circa 1900 to early 1930's)24

Vernacular is not a style "per se", but rather a common method of typical early construction in South Florida. Local craftsmen used traditional building methods and readily available materials, typically wood frame or masonry. Forms are simple with little or no ornamentation.

Early Transitional is a unique local hybrid style, which combines basic elements of Vernacular together with specific features typical of Mediterranean Revival, or vice versa. Examples include Mediterranean-style clay tile roofs and round-arched roofs together with lathed woodwork and the simple of Vernacular.

\section{Mediterranean Revival (circa mid 1010's to early 1930's)25}

${ }^{24}$ The City of Miami Beach Planning/Preservation Department. Historic District Designation Report. 
Mediterranean Revival architecture was the "style of choice" for the first major boom period in Miami Beach. Its connotation of Mediterranean resort architecture, combining expressions of Italian, Moorish, North African, and Southern Spanish themes, was found appropriate and commercially appealing image for the new Floridian seaside resort; it was a style that was simultaneously being used expansively in California and other areas of similar climate.

During the mid 1910's through the early 1930's, the style was applied to hotels, apartment buildings, commercial structures, and even modest residences. Its architectural vocabulary was characterized by stucco walls, low pitched terra cotta and historic Cuban tile roofs, arches, scrolled or tile capped parapet walls, and articulated door surrounds, sometimes utilizing Spanish Baroque decorative motifs and Classical elements. Feature detailing was occasionally executed in keystone or patterned ceramic tile.

Application of the architectural vocabulary in Miami Beach ranged from sparing to modestly exuberant, and building massing varied from simple rectangular form to step massing with recessed wall planes and tower-like corner features. Wooden casement or double-hung windows of several configurations provided additional detail to the facades.

\section{Mediterranean Revival/Art Deco Transitional (circa late 1920's to mid 1930's) ${ }^{26}$}

"Med/Deco" in Miami Beach was a synthesis of Mediterranean Revival form and Art Deco decorative detail or vice versa. This unique hybrid style became a fascinating bridge between the "familiar" and the "new" as the allure of Art Deco found its way into the City's architectural vocabulary. Clean stepped rooflines and crisp geometric detailing replaced scrolled parapets, bracketed cornices, and Classical features on structures of clear Mediterranean Revival form. Likewise, slopped barrel tile roofs rested gracefully on edifices with spectacular Art Deco entrances and façade treatments.

Some of the most celebrated architects in Miami Beach designed structures in this brief-lived but very significant style, including V.H. Nellenbogen, Henry Hohauser, Russell Pancoast, and T. Hunter Henderson. The predominant exterior material of Med/Deco Transitional was smooth stucco with raised or incised details. Featured stucco areas were often

\footnotetext{
${ }^{25}$ The City of Miami Beach Planning/Preservation Department. Historic District Designation Report.
}

${ }^{26}$ The City of Miami Beach Planning/Preservation Department. Historic District Designation Report. patterned or scored. Keystone, either natural or filled and colored, was frequently used to define special elements. Windows ranged from wood and steel casement to wood double-hung, and even large single windows in gracefully curved masonry openings.

\section{Art Deco/Streamline Moderne27}

Although Art Deco is the "mother" style, Streamline Moderne rapidly evolved and ran concurrently with Art Deco as the dominant design branches. Consequently, the examples of these styles in Miami Beach typically embody characteristics of both styles as summarized below.

\section{Art Deco (circa late 1920 's to 1930 's). 28}

The style now commonly referred to as Art Deco is considered one of the first twentieth century architectural styles in America to break with traditional revival forms. It emanated largely from the impact of the 1925 Paris Exposition des Arts Decoratifs et Industriels Modernes, a design fair celebrating the reconciliation between the decorative arts and advancements in technology and industry. ${ }^{29}$ Architects searching for design "purity" became eager to explore new possibilities afforded by the rapidly evolving Machine Age. ${ }^{30}$ An Architectural style unfolded which looked to both the past and the future for its design inspiration.

Building forms in the Art Deco style were typically angular and clean, with stepped back facades, symmetrical or asymmetrical massing and strong vertical accenting. The preferred decorative language included geometric patterns,

\footnotetext{
${ }^{27}$ The City of Miami Beach Planning/Preservation Department. Historic District Designation Report.

${ }^{28}$ The City of Miami Beach Planning/Preservation Department. Historic District Designation Report.

${ }^{29}$ Metropolitan Dade County, From Wildemess to Metropolis, Second Edition (Metropolitan Dade County, Office of Community Development, Historic Preservation Division, 1922), p. 187. ${ }^{30}$ Barbarara Capitman, Michael D. Kinerk, and Dennis W. Wilhelm, Rediscovering Art Deco U.S.A.; A Nationwide Tour of Architectural Delights (New York: Viking Studio Books, 1944), p.2.
} 
abstracted natural forms, modern industrial symbols, and ancient cultural motifs employing Mayan, Egyptian and Indigenous American themes.

In Miami Beach, a unique form of Art Deco employed nautical themes as well as tropical floral and fauna motifs. Ocean liners, palm trees, flamingos, and numerous related elements graced the exteriors and interiors of the new local architecture. The favored materials for executing this distinctive "art" décor included bas-relief stucco, keystone, etched glass, a variety of metals, cast concrete, patterned terrazzo, and others. Today this distinctive design vocabulary, which further incorporated glass block, Vitrolite, and stunning painted wall murals, has become the hallmark of Miami Beach's internationally recognized Art Deco gems.

\section{Streamline Moderne (circa 1930's to 1940's). ${ }^{31}$}

As "Art Deco" evolved in transportation and industrial design began to have an even greater impact upon new construction. The "streamlined" character of automobiles, airplanes, trains, buses, ocean liners, and even home appliances inspired powerful horizontal design compositions, accentuated by striking vertical features and punctuated by icons of the technological era. Continuous "eyebrows", racing stripe banding, radio tower-like spires, portholes, and deck railings like those found on grand ocean liners, were among the unique features to set this architecture apart from anything before it. The creative incorporation of nautical themes showed this advancing form of Art Deco to be true to its origins in Miami Beach.

Smooth, rounded corners often replaced sharp ones on Streamline Moderne buildings, especially on corner lots. "Eyebrows" swept around the corners as did other details. Street corners became inviting architectural focal points, whether the special treatment employed was based upon curves or angles.

Like earlier Art Deco buildings, the Streamline Moderne style incorporated smooth and articulated stucco, architectural glass block, keystone, and a variety of metals used in detailing. Predominating surfaces became smooth, planar, and aerodynamic in character.

${ }^{31}$ The City of Miami Beach Planning/Preservation Department. Historic District Designation Report.

\section{Classical Revival - Art Deco Style (circa 1930's to mid 1940's) ${ }^{32}$}

During the 1930's in America, buildings of a religious or monumental nature often relied upon the form and language of Classical Revival architecture as a means of ensuring a traditional and formidable presence in the community. In Miam Beach, however, the tide of Art Deco was strong. Buildings that exhibited Classical form also displayed architectural features and decorative elements that were significantly influenced by the Art Deco architecture of the Beach. For example, cornices and molding bands were designed to feel more like the continuous "eyebrows" of the Streamline Moderne Style.

\section{Post War Modern (1945 to late 1960 's $)^{33}$}

The Post War Modern style in Miami Beach exhibited many elements of its companion style of the period, Post War Deco, but clearly established a path of its own in terms of modern functional simplicity. Essentially the strong design personality of Art Deco, as it evolved over two decades in Miami Beach, significantly gave way to the dictates of function in the Post War Modern seaside resort architecture.
In 1922, the Martha Hills Apartment building was constructed at 850 Ocean Drive. Architect Henry La Pointe originally designed this rectangular, two-story building. This structure suffered severe alterations to its architecture and is therefore not considered an historic building. Yet, it is still an early example of a small-scale vernacular architecture that has been altered, but still retains its conforming scale and siting. ${ }^{34}$

Today, the Martha Hills Apartment building hosts the Café Milano restaurant at its entrance level. (Figure 8)

${ }^{32}$ The City of Miami Beach Planning/Preservation Department. Historic District Designation Report.

${ }^{33}$ The City of Miami Beach Planning/Preservation Department. Historic District Designation Report.

${ }^{34}$ Miami Beach Planning Department Building Cards - Ocean Drive.

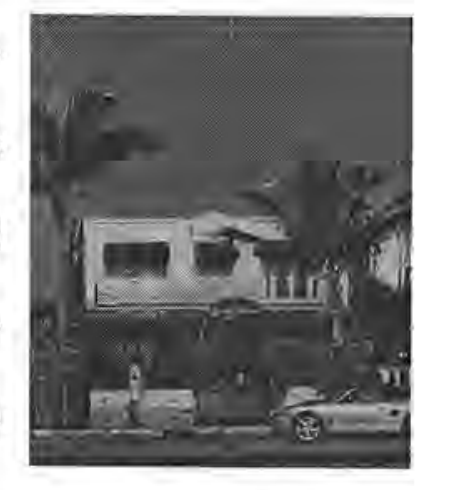

$$
\text { (1) }
$$


In 1923, at 312 Ocean Drive, The Biltmore Place was constructed. It is located in the Ocean Beach District and was designed by architect J. Gannon. It is considered a contributing building and remains in a good condition. Its current use is residential apartments. Its crest and the top of its façade are typical of the Mediterranean Revival style of architecture..$^{35}$

During 1923, the Casa Grande Apartments was built at 834 Ocean Drive. Designed by architect August Geiger, it is a 32 feet high, $U$-shaped building containing eighteen apartments. It has a broad raised terrace and a minor green space within the $u$-shaped space of the building. It is attached to 844 Ocean Drive. The building is considered a historic building and a good example of the Mediterranean Revival style of architecture, with typical architectural features of the style on the east elevation. Some architectural features are the arch-topped chimney and the tile roof. In the interior, the wide arched entry is the only remaining distinguishing feature.$^{36}$ According the Planning and Preservation Department of Miami Beach, the building has suffered some alterations and deterioration that does not affect its significance. Today the building maintains its original name but it is zoned for mixed-use. At the entrance level of the Casa Grande building, now stands the Mezzaluna restaurant while the rest of the building is the Suite Hotel. (Figure 9) The building mixes a stucco façade of the Mediterranean Revival style

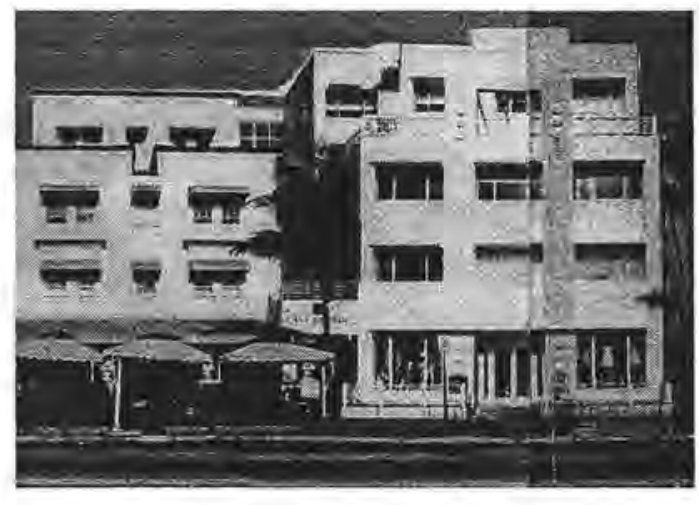

of architecture and a new addition in glass between the structure at 834 Ocean Drive and 844 Ocean Drive. This building offers a particular feature of having a vertical circulation volume as a transition element between the two buildings.

Also in 1923, arose the Flambeau Apartments, at 1126 Ocean Drive. A two-story building substantially altered over the years, it was demolished in the early 1990s, and

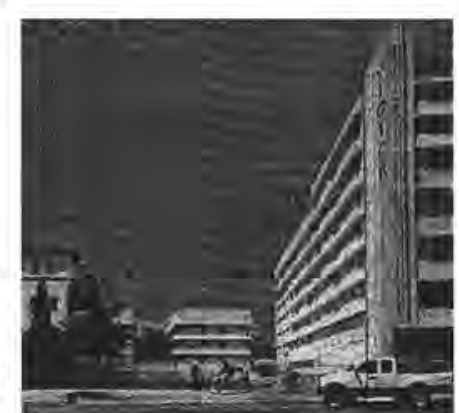
now remains as an empty lot, at Leonard Horowitz PI, or $11^{\text {th }}$ street, next to the south of the Victor Hotel. (Figure 10)
In 1925, Willard Meyers designed and constructed the Ocean Drive Hotel at 760 Ocean Drive on the south corner of $8^{\text {th }}$ Street. Even though it is one of the oldest buildings on Ocean Drive, it has suffered severe alterations that remove any significance to the building and is not considered historic. Its scale and original 24 feet height have been maintained. Today, the building serves as a two story bar in a mixed-HPD-use Zoning. (Figure11)

The City of Miami Beach Planning, Design and Historic Preservation Division, provides for a division of the land use and zoning distribution in categories according to uses: residential, commercial, mixed-use, recreation and open space, marine recreational, light industrial, public facilities, conservation protected and parking. Also, this classification is done according to population density.

Generally, the southern part of Miami Beach tends to be R-PS (residential, high density) combined with ROS (recreation and open space), with higher density levels towards the beach and the Atlantic Ocean. The area along South Beach, including Ocean Drive, southern Collins and Washington Avenues, is MXE (mixed-use entertainment.) Lincoln Road is CD-3 (commercial, high intensity.) ${ }^{37}$ In chapter 142, Zoning Districts and Regulations, from the City Code of Miami Beach, the zoning divisions and regulations are established. "To achieve the purposes of these land development regulations, the Code of the city, and regulate the use of land, water and buildings, height and bulk of buildings and other structures, and population density and open space, the city is herby divided into districts." ${ }^{38}$ Example: RS- 1 is the symbol for a Single-family residential district

During 1925 , the Park Hotel was built at 928 Ocean Drive. This three-story, 35 ' high building was originally a Vernacular Style of architecture but was altered into a Moderne Style. G.H Hyde designed the Park Hotel. The building is now called Park Retirement Home and its main urban features are that the building cantilevers over a raised terrace, and is supported by square columns. ${ }^{39}$ (Figure 12)

\section{${ }_{37}^{36}$ bid,}

Official Map of Miami Beach-Land Us

Mode the Clly of Miami Beach, Florida. Chapter 142 zoning Districs and Regulations

${ }_{33}$ Miami Beach Planning Department Building Cards - Ocean Drive. 
The following year, 1926, saw the construction of the Locust Apartments, at 918 Ocean Drive. This 3-story building contains many architectural features of significance such as the arches, pilasters, cornices, etc. Also, in the interior, the fireplace, with its twisted columns, is an element of significance. This structure is one of the few early buildings in Ocean Drive that maintains its interior significance. (Figure 13) It has a $10 \mathrm{ft}$ setback, a ground floor front terrace, and a masonry banner above the entry, as a signage element. ${ }^{40}$ This building is the only example of Venetian Gothic Revival style of architecture within the Art Deco District. 41

In 1929, after the 1926 Hurricane, the Beach Paradise Hotel was built at 600 Ocean Drive. It is a 3-story hotel originally called the Beach Park Hotel. This is a historic L-shaped building of the Mediterranean Revival style of architecture. It contains important interior features, such as a fireplace and a beamed and coffered cypress ceiling. The building has a long front terrace and pierced masonry block balustrade at the entrance. ${ }^{42}$ (Figure 14) Today, next to this site, towards the north, is a vacant lot. Only six vacant lots remain in Ocean Drive as it is today.

During the 1920s, there were major developments in other areas within the Historic District. In this decade the Flamingo Hotel, the Miami Beach Aquarium, the Nautilus Hotel and the Wofford Hotel, were constructed. All these developments led to the naming of this period of time as the Boom years. By 1925, there were 56 hotels, 178 apartment houses, 858 residences, 308 shops, and offices and another 20 buildings in Miami Beach. ${ }^{43}$

The architectural styles found on Miami Beach and in much of America during the later part of the 1920s were profoundly changed by exposure to European designers. For example, the Exposition Internationale des Arts Decoratifs et Industriels Modernes, took place in Paris, in 1925. This fair was a place for the fusion or integration of the arts that led to the development of the Art Deco and encompassed many new styles of great influence on the architecture to be built in the 1930s in Miami Beach. Other factors led to change on Miami Beach as well. In September of 1926, a very Severe hurricane struck South Florida. (Figure 15) It caused substantial loss of life and property damage, even though comparatively few buildings were actually destroyed. It caused significant economic damage. After the hurricane, the land value dropped and development in Miami Beach never recovered during that decade. Between 1927 and 1929, only one building was constructed in Ocean Drive, the Beach Paradise Hotel. In 1929, the worldwide stock market crash led to the Great Depression that caused an economic decline within all the United States and around the globe.

\section{The Post Depression "Boom" Years, 1930-1941.}

From 1930 to 1941, were called the Post Depression "Boom" Years.44 (Figure 16) Miami Beach had entered an economic decline even before the Great Depression, as a result of the hurricane that hit the city in 1926. In a similar manner, the city recovered before other parts of America. During the 1930's, the automobile became a phenomenon, by the time; there was one car for every five persons. In the arts and culture, aesthetics became more important than function. The years from 1930-1935 were a period of transition for the architecture that was designed along Miami Beach. Building styles changed from the construction of 1920's Mediterranean Revival style to the three-dimensional Streamline Moderne and Art Deco architecture.45 Building construction between 1930 and 1941 was a process of accommodating to the pattern of land usage established during the 1920s. This period was marked by a new optimism reflected in the architectural styles and also by a more modest typology of building construction along Miami Beach.

The building boom of the 1930 s and early 1940 s, led to the construction of more than 1000 buildings in southern part of Miami Beach. In 1937, for example, 150 hotels and 508 apartment buildings were constructed in South Miami Beach.46 A group of fewer than 10 architects, coming mainly from the northern states, designed many of the buildings in the Art 


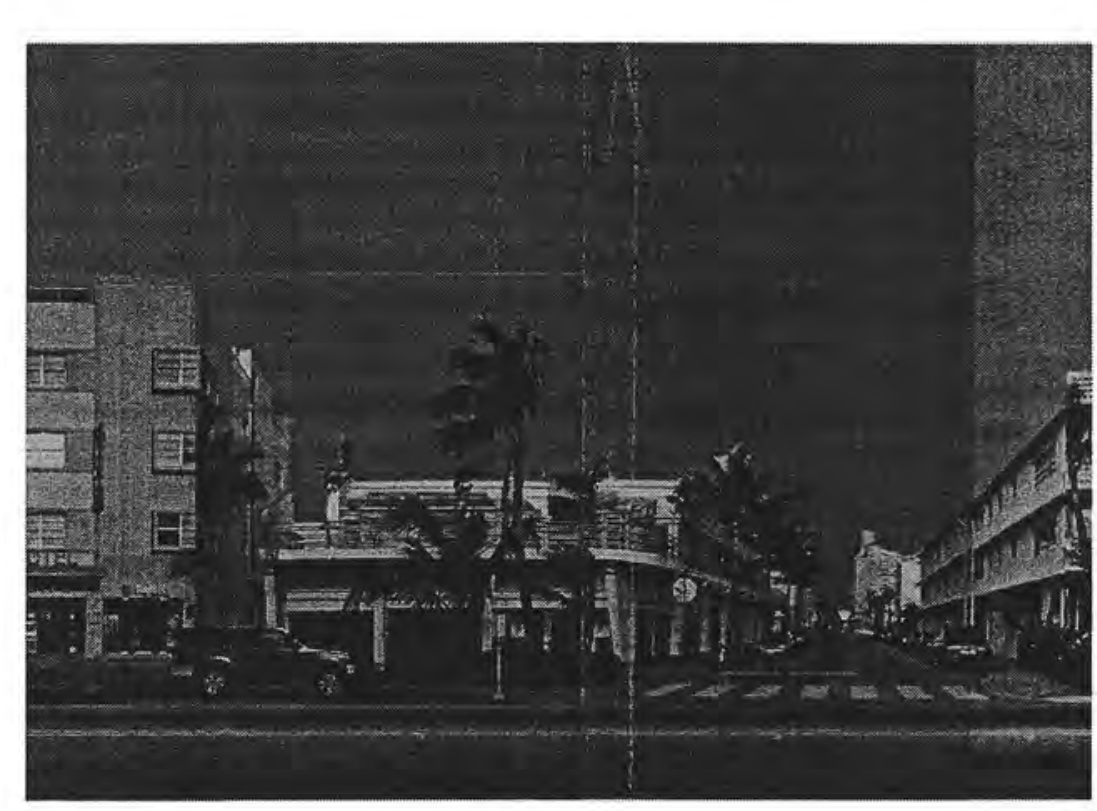

Fig. 11

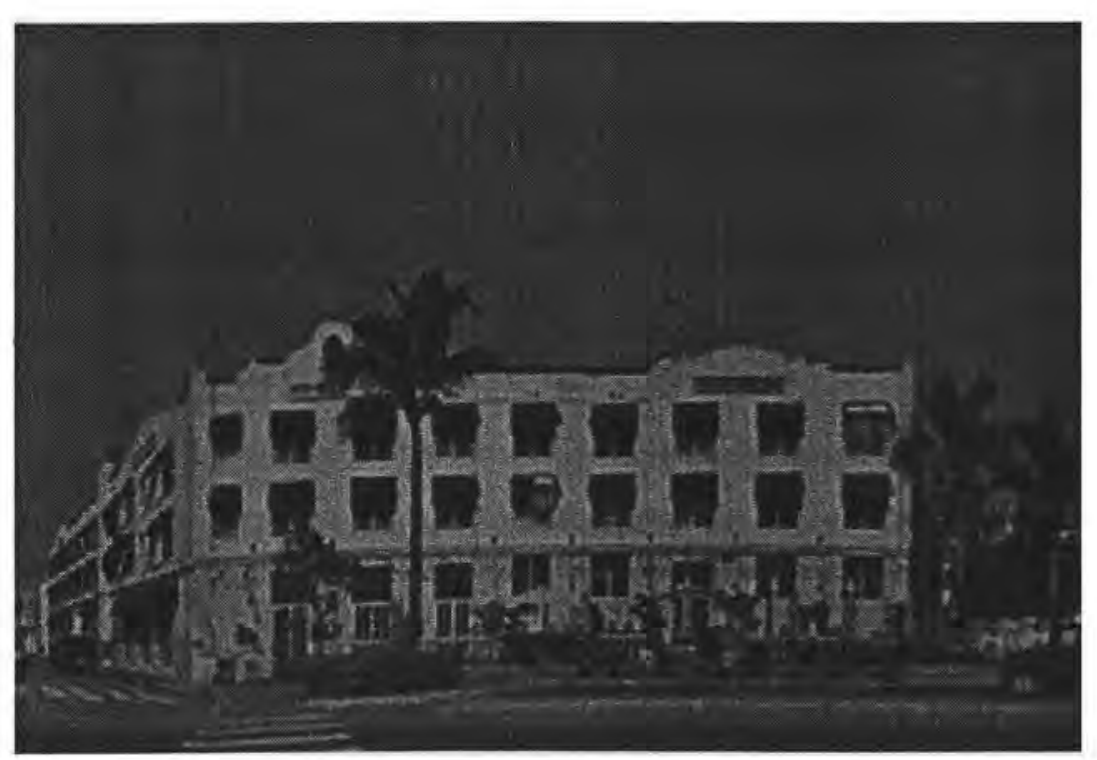

Fig. 14

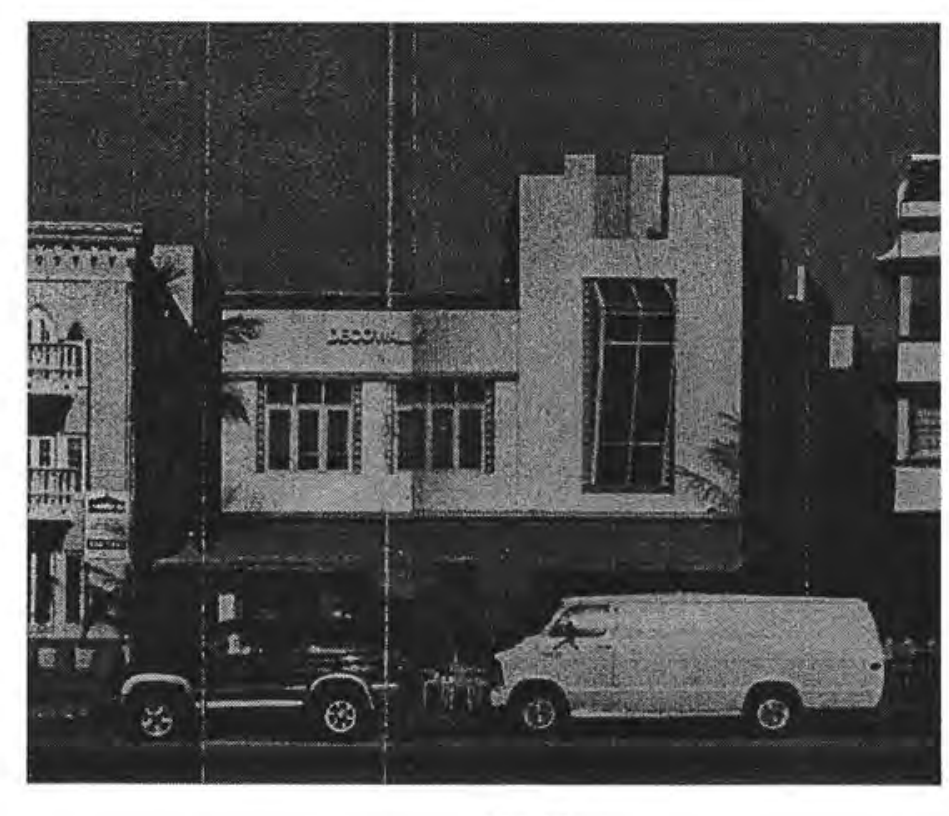

Fig. 12

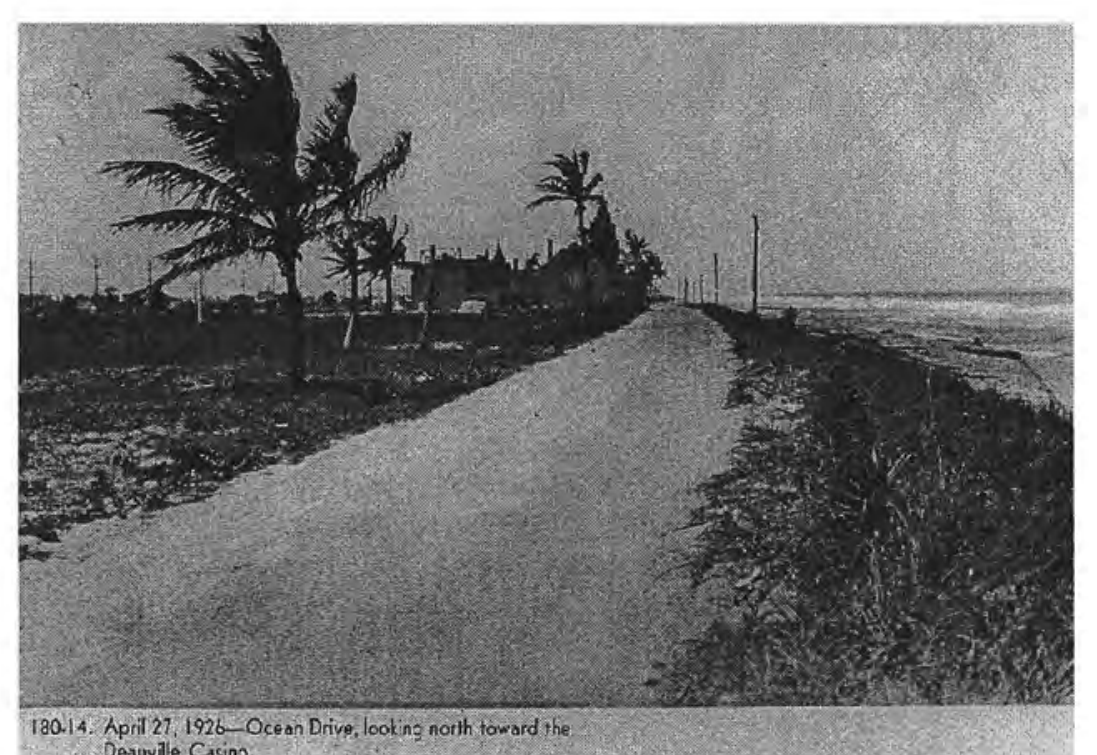

Fig. 15

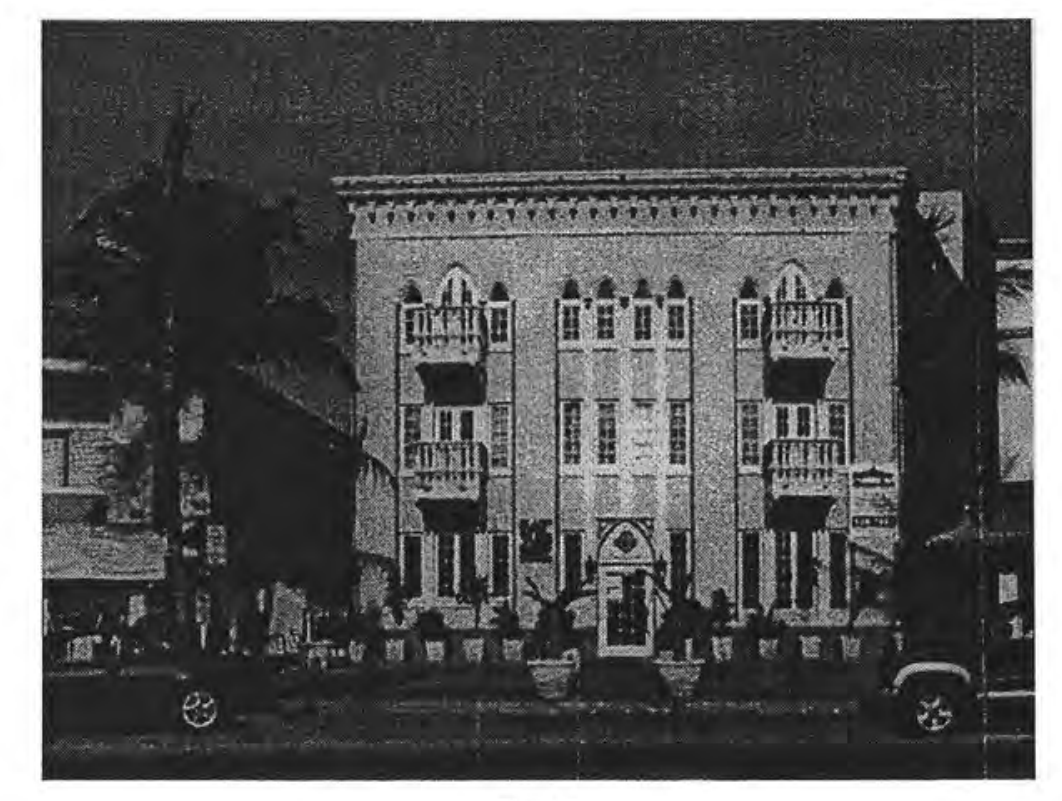

Fig. 13

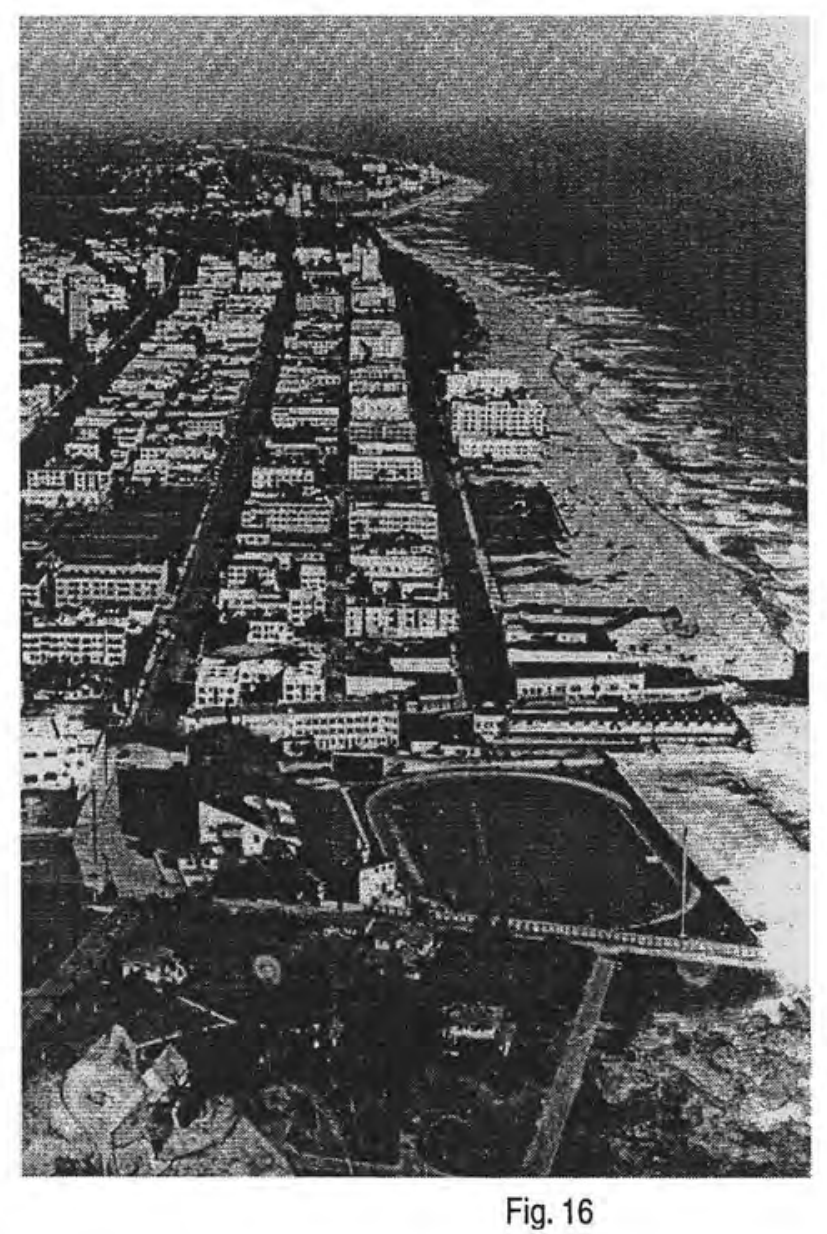


Deco district in frantic pace, giving neighborhood cohesiveness to the architecture and urban development in the area.

On Ocean Drive, there were 47 buildings constructed between 1930 and 1941. In the following section of the essay, there is a chronological and stylistic recount of the construction and history of some of the most important buildings constructed during that time on the basis of mentions in historic preservation documents and others, related to the development of Miami Beach. This analysis will help to understand the profile of the development in the area:

In 1930, The Amsterdam Palace, a three story residential building, was constructed on Ocean Drive between $11^{\text {th }}$ and $12^{\text {th }}$ Street. The designer was Henry La Pointe. The building was originally called "Casa Casuarina" after an Australian pine, which was growing on the lot. A modern sculpture of "Kneeling Aphrodite" by Vuc Vuchinich marks the pointed arch entranceway. It was modeled after the Alcazar de Colon (Castle of Columbus), which was the home of Diego Columbus, son of Christopher Columbus, in the Dominican Republic ${ }^{47}$.

A brick from that original house was placed in a cornerstone of this property at 1116 Ocean Drive. It is the finest example of Mediterranean Revival architecture on Ocean Drive, a richly asymmetrical design that once contained 24 apartment units. ${ }^{48}$ Until recently, was owned by fashion designer Gianni Versace and the building served as his personal residence. Some architectonic characteristics are the raised keystone steps and terrace at the entrance of the building. (Figure 17)

At 960 Ocean Drive stands the Edison Hotel built in 1935 by architect Henry Hohauser. It is a 67 room, 57'6" high building on a corner site next to $10^{\text {th }}$ street. Its architectural style is Mediterranean Revival adapted to a Modern context. ${ }^{49}$ This building shares a swimming pool built in 1956 with the Breakwater Hotel. The building is highly

In 1936, at 1220 Ocean Drive architect L. Murray Dixon built the Tides Hotel. It is a 12-story building with one hundred and fourteen rooms that for many years was the tallest historic building on Ocean Drive. The keystone in the walls (natural and dyed keystone), the 3-stair terrace at the entrance, its height and setback are the major architectonic and urban characteristics of the building. It does not maintain a highly cohesive scale with the neighborhood buildings, an uncharacteristic feature of buildings along Ocean Drive. (Figure 21)

story, 80 ' high building, is one of the tallest in Ocean Drive. The basement entry and the fountain at the entrance of the building are some major characteristics of this building. It is a good example of the Art Deco style of architecture, with additional significance due to its size (103 room hotel) and siting, an unusual triple lot, a 35 ' setback and a zigg zagg side entry.50(Figure 19)

Also in 1935, the Irene Marie apartment building was constructed at 728 Ocean Drive. Its original name was Sun Ray Apartments. It is a two story, 20ft high building listed as contemporary. Architect Don Reiff designed it. This building is conforming mainly in scale to the Historic District, and presents an ocean front façade of stucco and brick..$^{51}$ (Figure 20) 


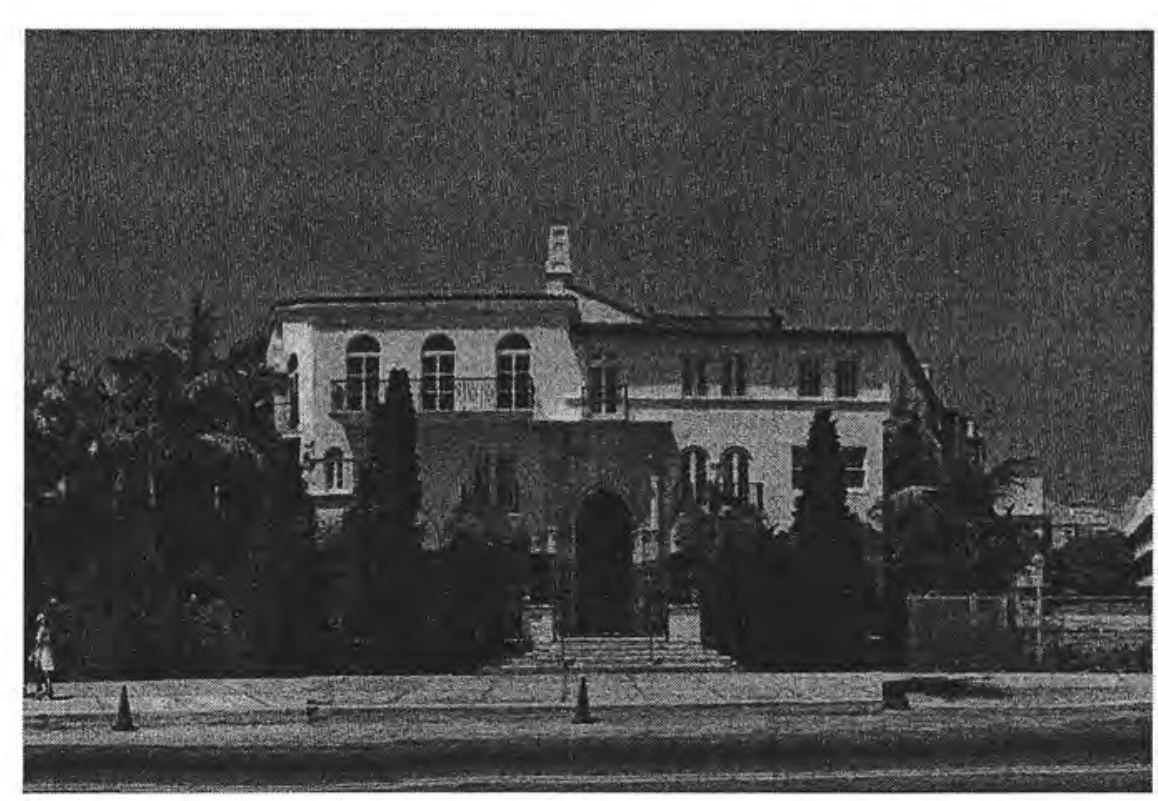

F. 17

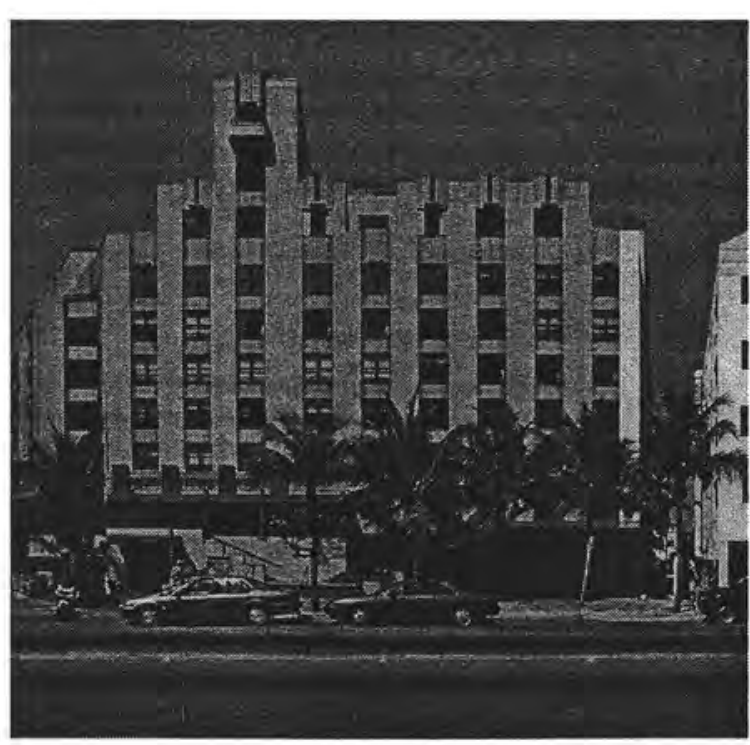

Fig. 19

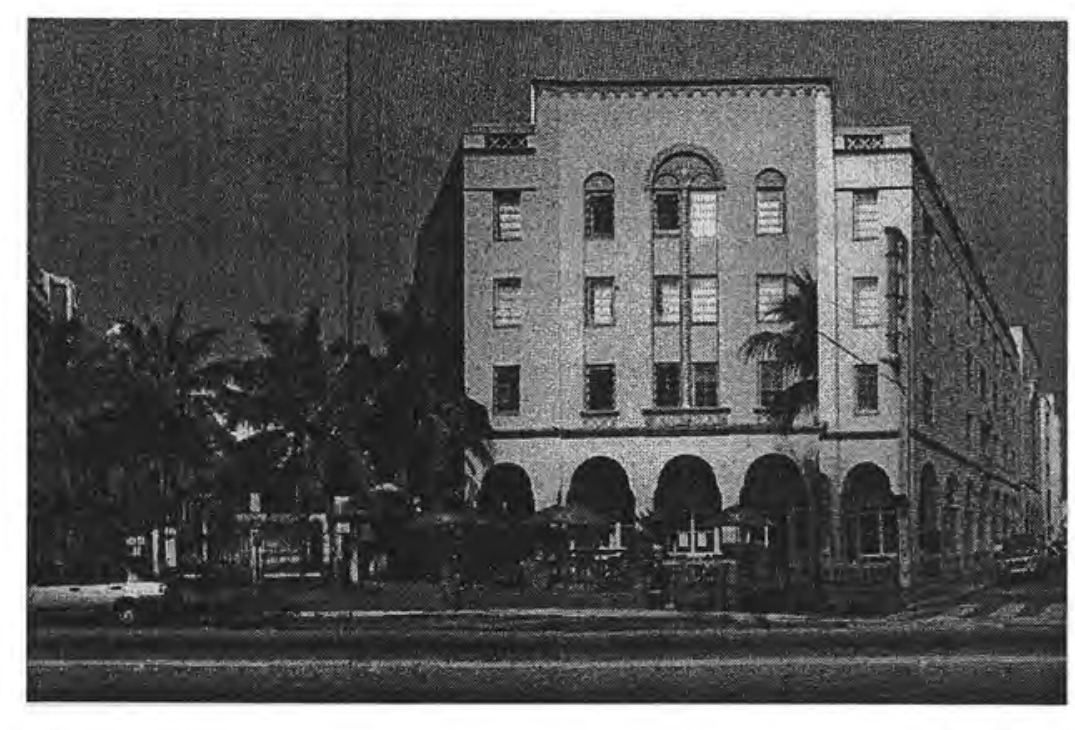

Fig. 18

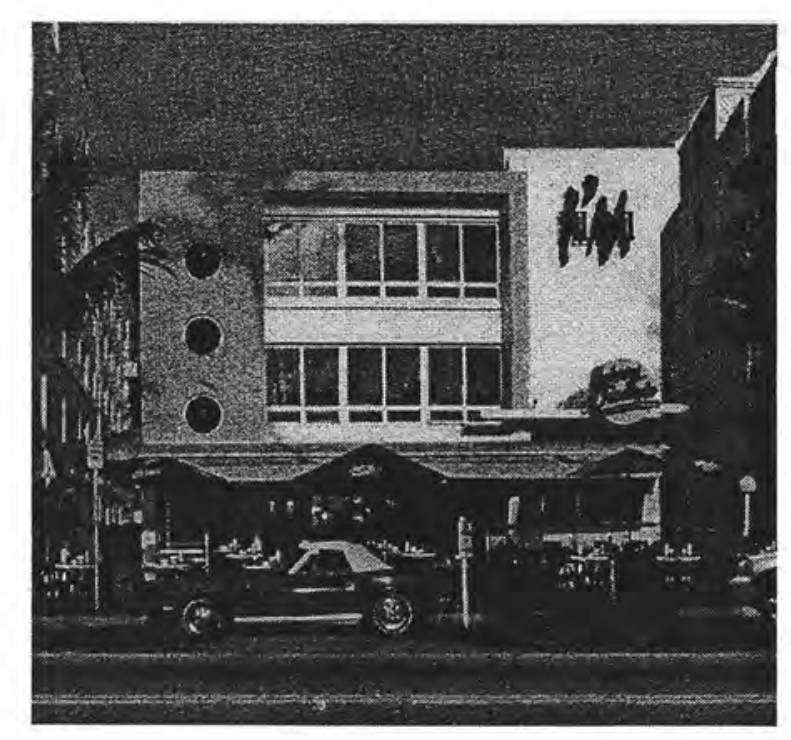

Fig. 20
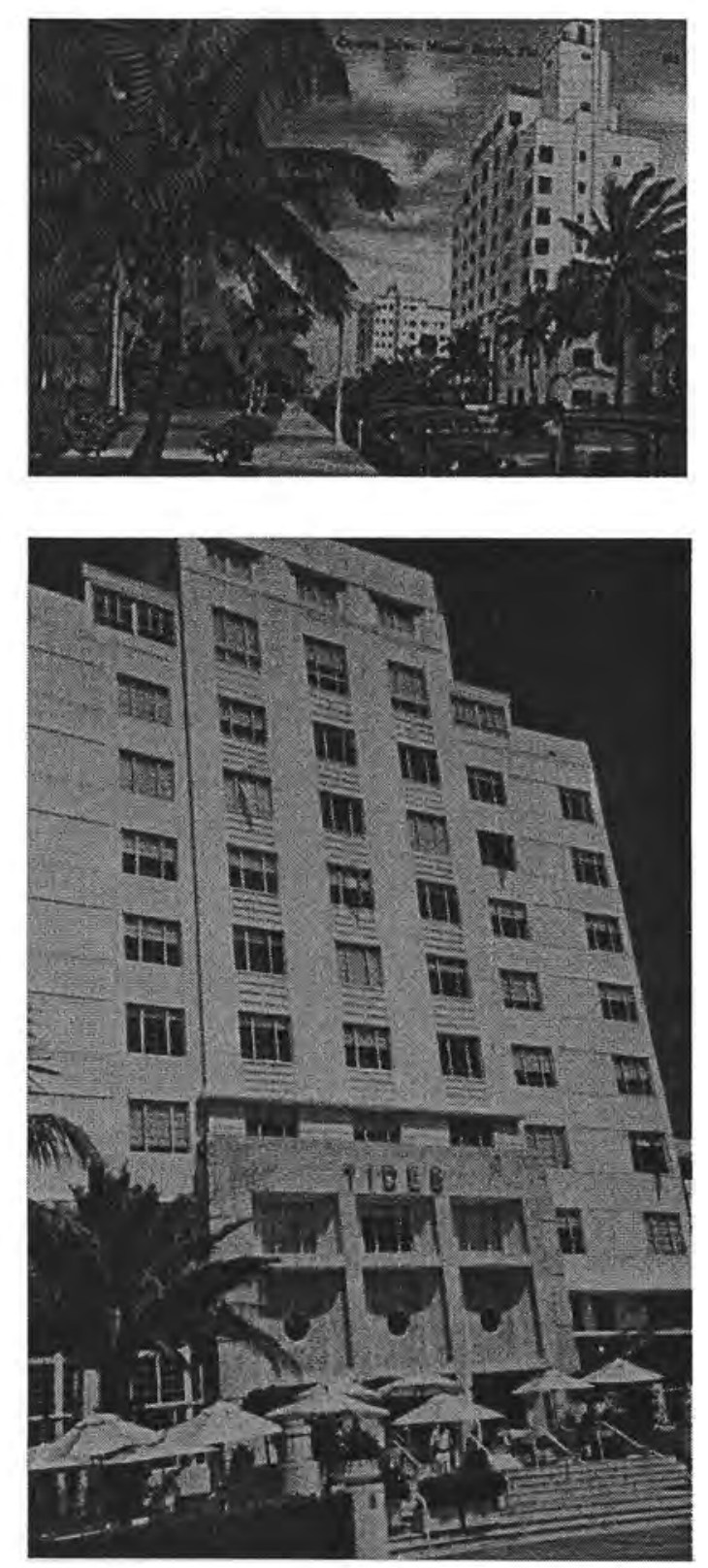

Fig. 21 
In 1937, at 640 Ocean Drive, Henry Hohauser built the Park Central Hotel. This building is an outstanding example of Streamline Moderne architecture and Hohauser's work. It contains a highly significant interior space composed of a large lobby wall, terrazzo floor, multi levels and a mezzanine. Its site and urban characteristics are, a large green area with what is currently a sculpture garden. It has suffered minor rehabilitation.52 (Figure 22)

The Waldorf Tower Hotel at 860 Ocean Drive was also built in 1937; Albert Anis designed it. It is located on a corner site next to $9^{\text {th }}$ Street. It is a 50-room hotel, 3 stories high. Its site and urban characteristics include its corner site, its side entry to the basement, a front terrace raised from the sidewalk level, and the masonry balustrade surrounding the terrace at the entry. Its major architectonic feature is its tower over the entrance on the corner of this Streamline Moderne building. The rooftop tower marks the corner at Ocean Drive and $9^{\text {th }}$ street but the main entrance faces the ocean. It has a strong nautical influence in its style of architecture with high neighborhood cohesiveness. (Figure 23)

At 1144 Ocean Drive stands the Victor Hotel built in 1937. The architect responsible for this eight story, 125ft high building was L.M. Dixon. This hotel is one of the earliest examples of the International Style of Architecture within Miami Beach. It is also one of the tallest buildings along Ocean Drive. The Victor Hotel contains a patio surrounding the ballroom. It used to have a decorative rail on the front terrace with large portholes carved in the concrete fence.53 Special features of this hotel are the pelican relief sculpture and a mural by Earl Le Pan in the lobby. The Victor Hotel contained a private parking lot to the South, at the adjacent site. Today the Victor Hotel is in process of being restored. The adjacent site is still owned by the Victor Hotel but is now an empty lot with vegetation and grass on it. (Figure 24)

In 1938, at 1020 Ocean Drive, the Clevelander Hotel was built. Architect Henry Hohauser designed this $59^{\prime} 6$ " high building that originally contained 60 hotel rooms within its five stories. This property consists of three lots and has one of the only original swimming pools built on Ocean Drive. A flying Saucer sculpture faces the Edison Hotel and the ocean..$^{54}$ This building contains a front terrace with a massive rail and a large open space in two of the lots of this property. This building has an outside bar in the pool area. According to the Miami Beach Planning Department, the hotel is considered a very good example of Art Deco/Streamline Moderne architecture with a significant height and high neighborhood cohesiveness. This means that the building generates continuity, and accommodates harmoniously, with the adjacent buildings. Height is important feature since of the 47 buildings constructed during the 1930's and early 1940's; most were two or 3 stories high. (Figure 25)

In 1939, The Breakwater Hotel was built at 940 Ocean Drive. It is a U-shaped, $36 \mathrm{ft}$ high building that originally contained 75 rooms. It is a Streamline Moderne building with the largest porch and neon sign vertical façade on Ocean Drive. ${ }^{55}$ Anton Skislewicz designed this building that shares a swimming pool with the Edison Hotel. Eyebrows and terrazzo floors are some of its significant architectonic features. The Breakwater Hotel shows great nautical influence in its design. (Figure 26)

During 1939, the Winter Haven apartment building was constructed at 1400 Ocean Drive. (Figure 27) The architect was Albert Anis and this building belongs to the International Style of architecture. This three story, $41 \mathrm{ft}$ high building is also considered non historic, conforming according to the Preservation Department. This building is located at a corner site at $12^{\text {th }}$ Street and the ocean and has a terrace with a metal rail facing Ocean Drive. ${ }^{56}$

Also in 1939, The Cardozo Hotel was built at 1300 Ocean Drive. Henry Hohauser designed this 40ft high building. It was originally designed to have 70 hotel rooms within its three floors. It is an outstanding example of the Streamline Moderne style of architecture. It is located at the corner of Ocean Drive and $13^{\text {th }}$ street. The South façade facing $13^{\text {th }}$ street has been altered, as has the interior of the building. The Cardozo Hotel is a symbol of the preservation movement represented by the Miami Design Preservation League (MDPL). In October of 1978, this hotel hosted the first Art Deco 


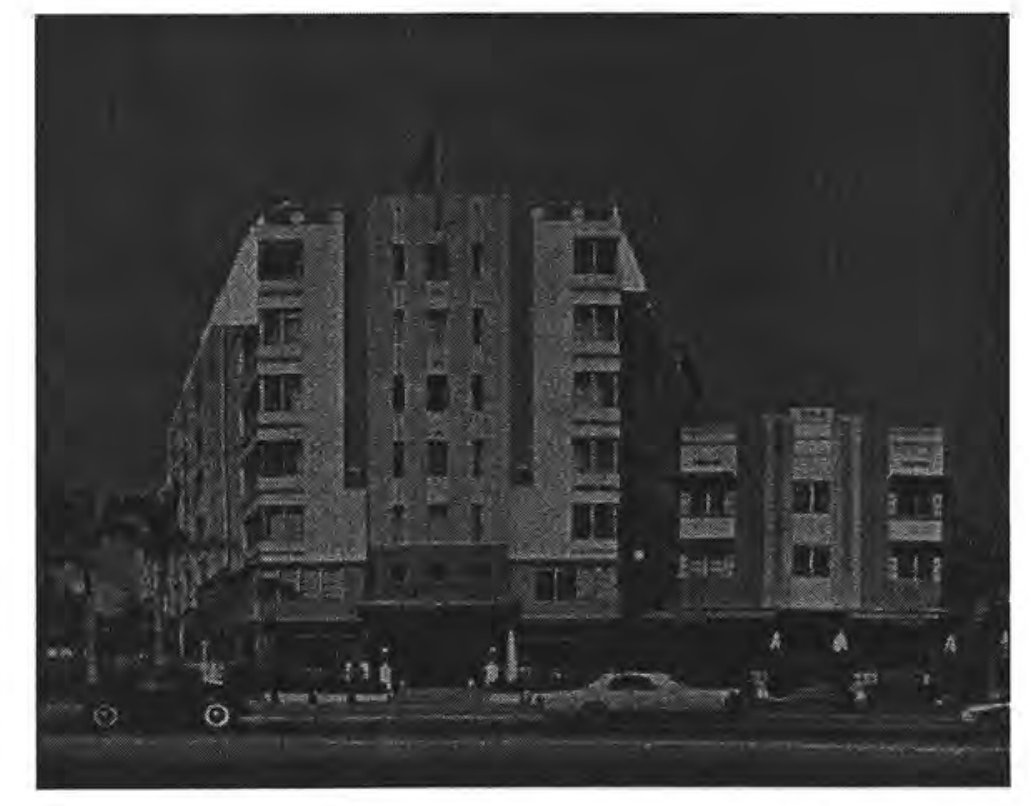

Fig. 22

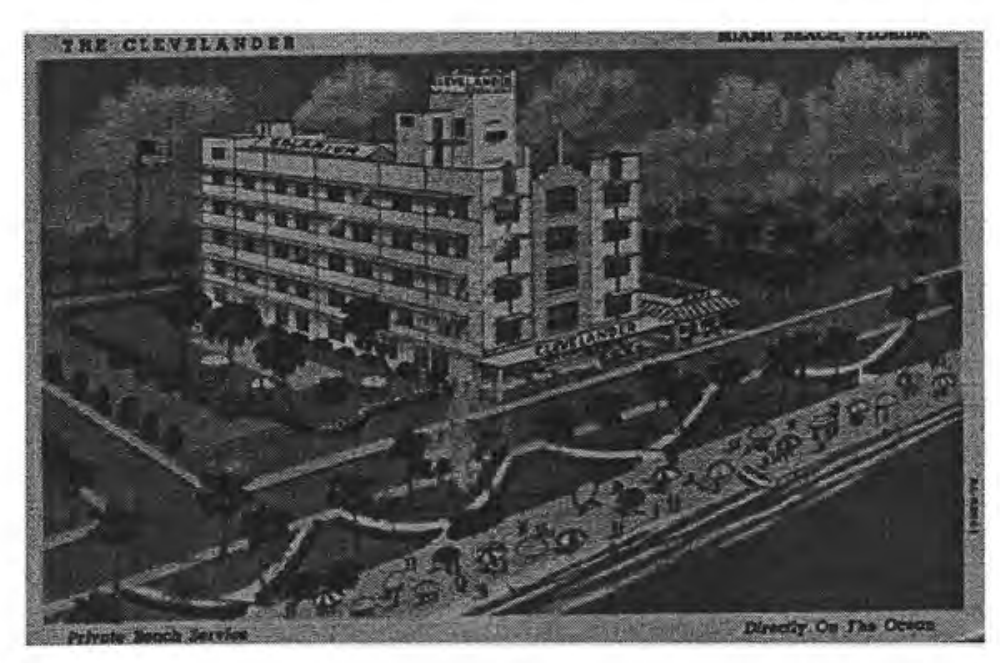

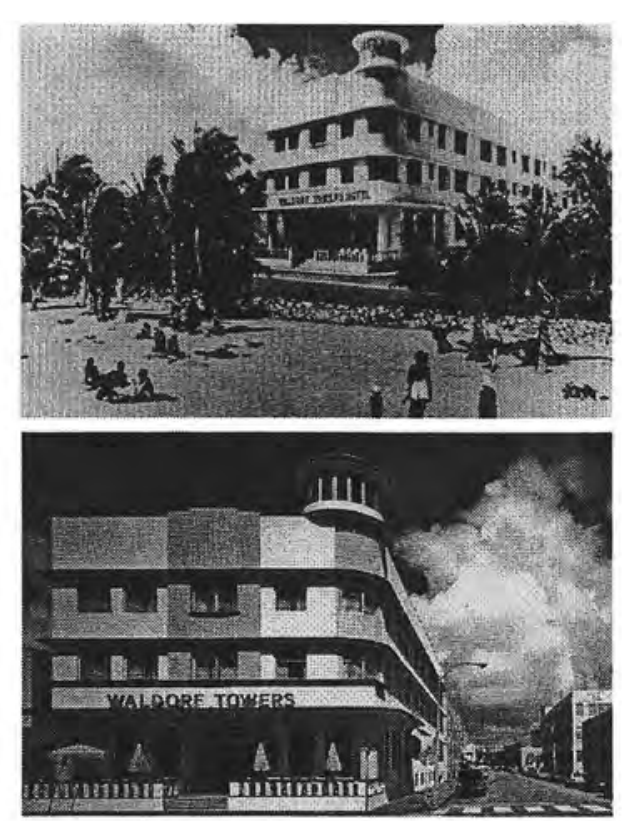

Fig. 23

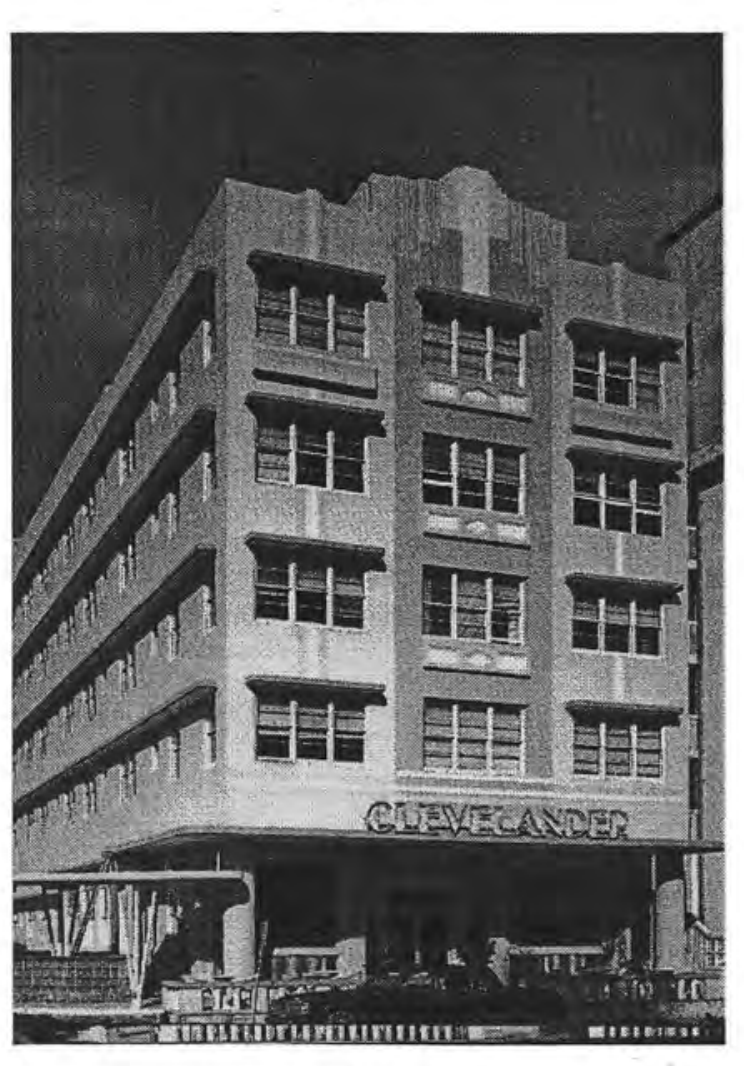

Fig. 25

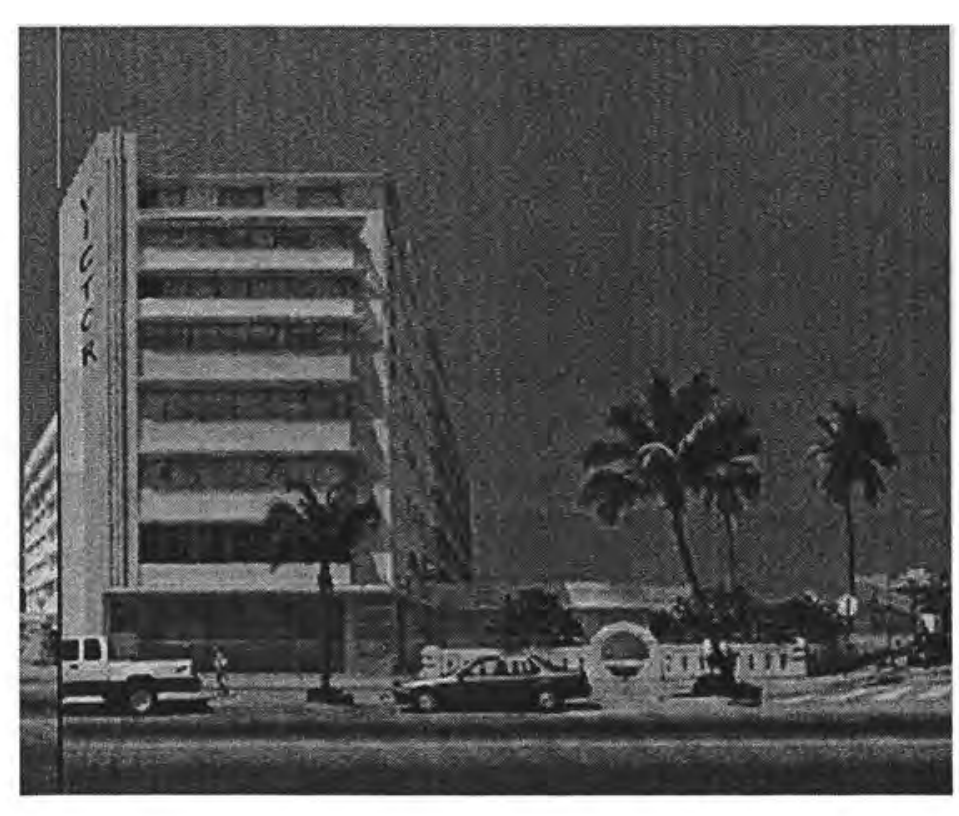

Fig. 24

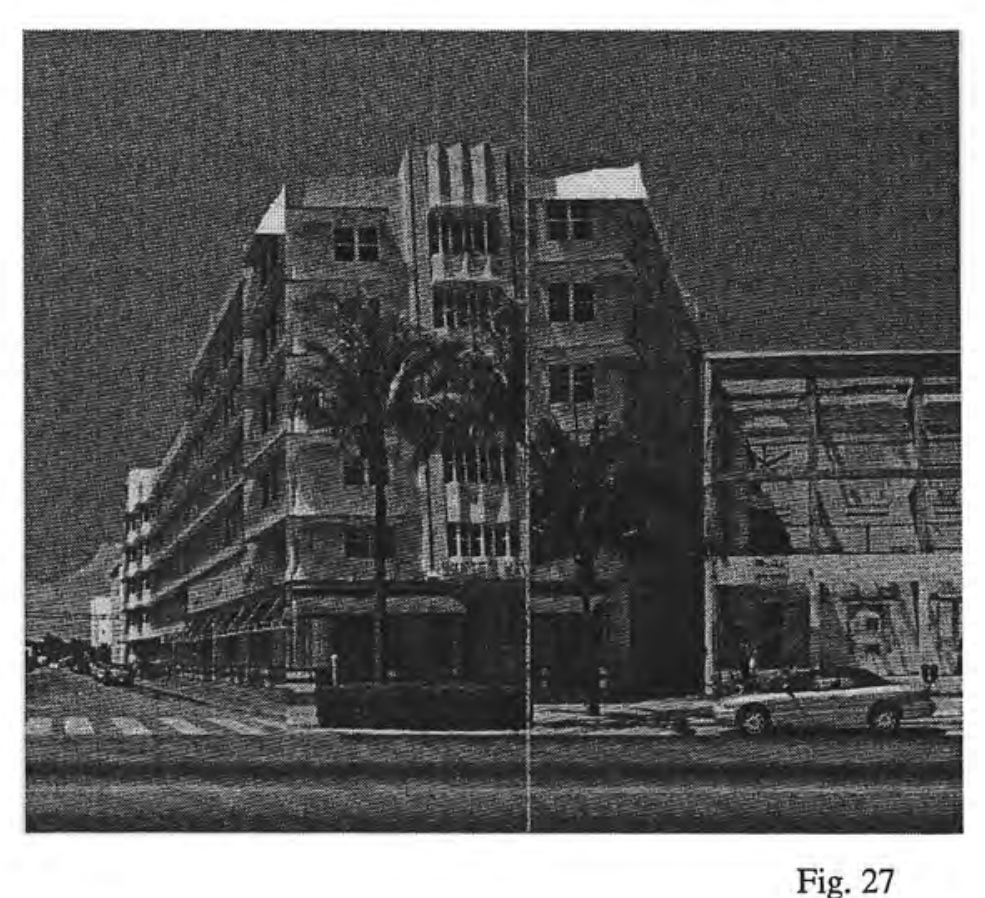

Fig. 27 
Week celebrated in Miami Beach. The Capitman family purchased the Cardozo Hotel in 1979 with the purpose of providing a demonstration project to display the unique features of the historic district. By that time, Barbara Capitman was the president and founder of the Miami Design Preservation League. In addition to its architectonic qualities and geographical conditions there were also emotional conditions for its selection by Capitman. It had always been Barbara Capitman's favorite building in the District due to the Streamline design of the structure with its rounded corners and courtyards. It was also a place of great memories for Mrs. Capitman. The Frank Sinatra movie "A Hole in the Head," was filmed in the Cardozo Hotel. ${ }^{57}$ (Figure 28)

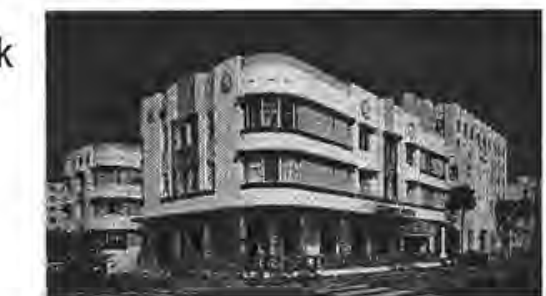

The Avalon Hotel, previously known as St. Charles Hotel is one of the last buildings on Ocean Drive to be considered Historic. Architect Albert Anis, at 700 Ocean Drive, constructed the Avalon Hotel in 1941. (Figure 29)

At 1430 Ocean Drive lies the Ocean Plaza, designed by L. Murray Dixon in 1941. This is one of the latest constructions on Ocean Drive to be designated as historic. The Ocean Plaza is a Streamline Moderne hotel previously known as Hotel Clyde. (Figure 30)

Also during the $1930^{\prime}$ 's, on Lummus Park, by $10^{\text {th }}$ street and Ocean Drive, the Historic Beach

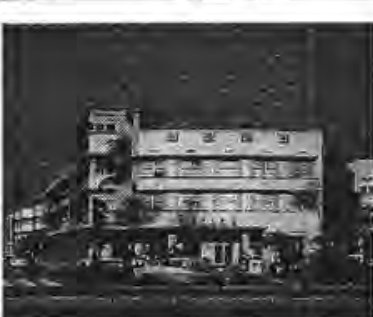
Patrol Station was built. (Figure 31) Later, The Oceanfront Auditorium was constructed at the back of the Patrol Station. (Figure 32) The Oceanfront Auditorium is also on Lummus Park at 1001 Ocean Drive. These two buildings form one volume. The Patrol Station and The Auditorium are together the only public buildings along Ocean Drive. They are the only buildings in Lummus Park and the only buildings directly connected to the beach between fifth and $13^{\text {th }}$ Streets.

The architectural development of Miami Beach during the 1920's and 1930's favored part of the barrier island, and comprised what is now the Art Deco Historic District. The buildings built at that time along Ocean Drive and south of $14^{\text {th }}$ Street, were less pretentious and less expensive than the buildings along Millionaire's Row, (a three-mile stretch along Collins Avenue were many millionaires built their mansions during the 1920s-1930s) and north of Miami Beach.
In 1930, the first zoning ordinance for the City of Miami Beach was established. It demanded a five-foot side-setback for multiple-residential properties. The height restriction was 15 stories or $150 \mathrm{ft}$. As a result of the ordinance and mainly in response to the setback regulation, the area of South Beach, including Ocean Drive, allowed the construction of building with separations of no more than 10ft. between them. This issue resulted in hotels having to attach signage towers as name emblems, to the buildings, in order to solve an identity crisis due to the proximity of the buildings to one another. However, this creative architectonic solution, led to decorative elements that gave additional character to area.

\section{The War Years, 1942-1945.}

1942 to 1945 were considered "the War Years". (Figure 33) During World War II, the difficulty in obtaining permits for non-essential projects to the government, the city and community, limited construction and development along Miami Beach. From 1945-1965, there was a Post War boom in the economy of Miami Beach.

\section{The Post War Boom, 1945-1965}

During the early 1940 s, most of the Historic District attracted tourism from the middle class and became a residential area for many senior citizens. The hotels along the area continued to work according to a seasonal tourism. Tourists from the $20^{\prime}$ 's and 30 's were coming back to the area as permanent residents. ${ }^{58}$ It was not until 1945 that a structure was built at 460 Ocean Drive. Currently, the property name is "Tommy To Go". It is a residential-commercial Mixed-Use building. The building is considered contributing since is one of the few Art Deco structures designed by architect Gerard Pitt. It reflects a simplicity resulting probably from the slowdown in construction due to the war. The architecture shows endurance of the style even though the ornamentation of the facades had decreased in comparison to the detailed ornamentation in architecture along Ocean Drive, constructed in previous years. Two years later, Martin Havre 

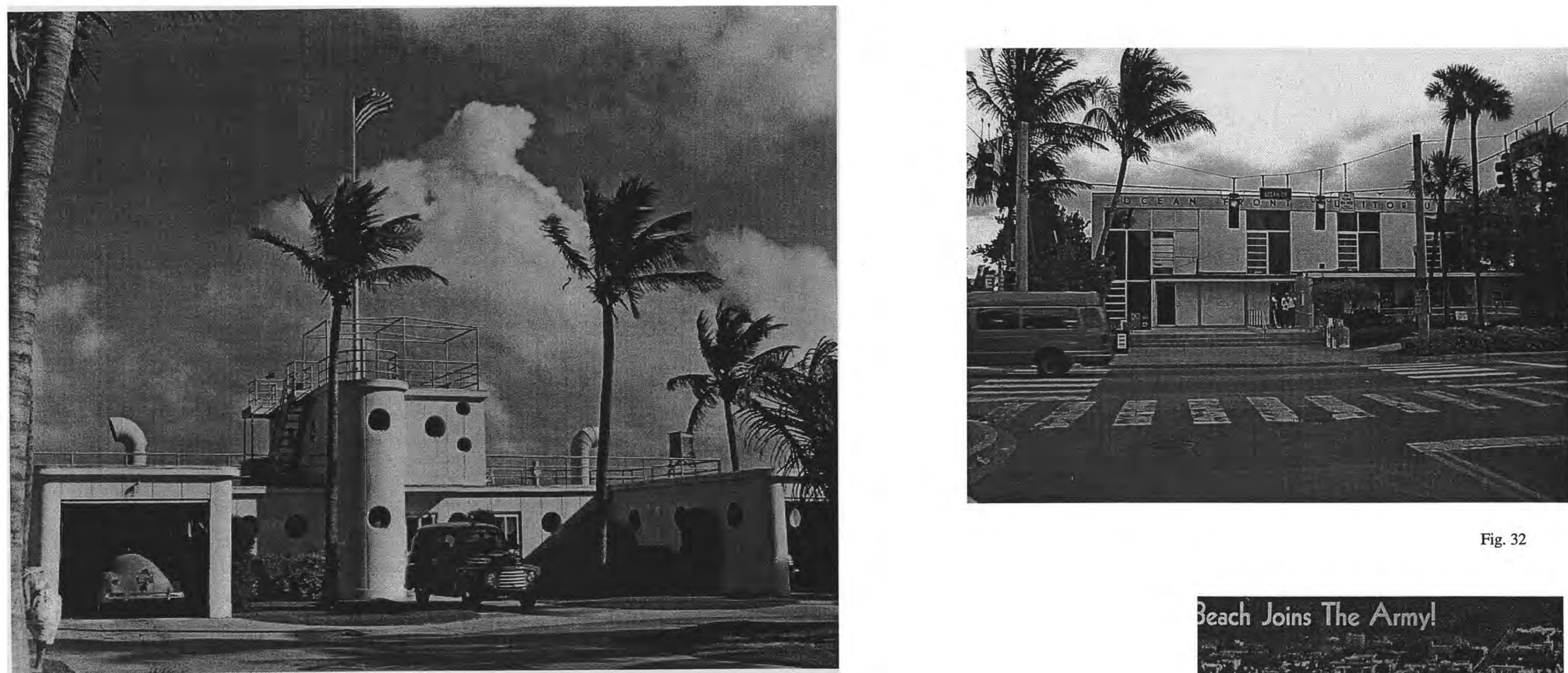

Fig. 32

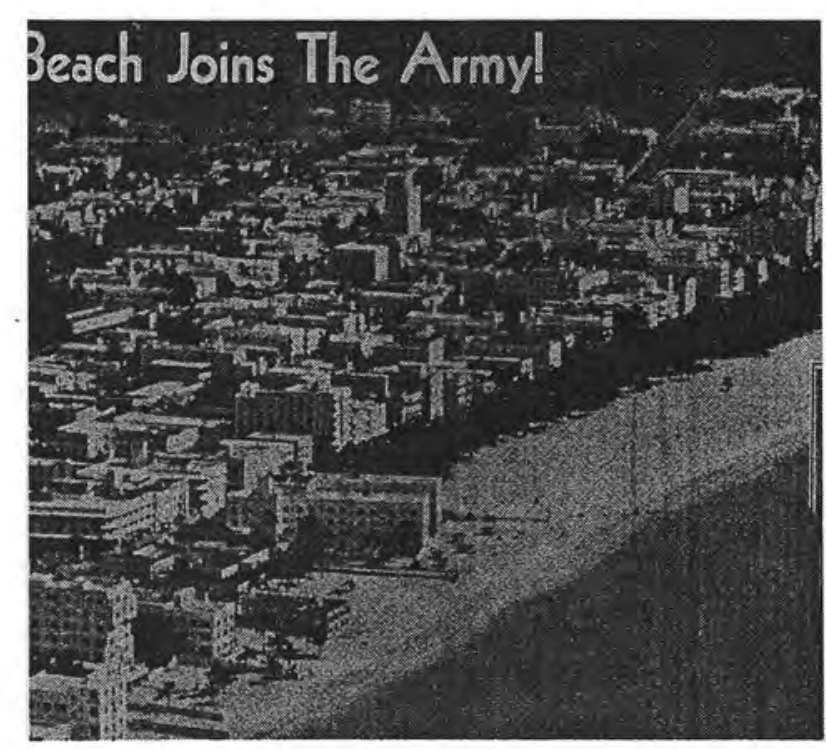


Designed an Art Deco building, at 412 Ocean Drive. This building is located at block 5 lot 8 between $4^{\text {th }}$ and $5^{\text {th }}$ street. Its zoning classification is RPS-459; it is the original subdivision for the zoning in that specific area.

In 1948, at 121 Ocean Drive, the Sea Crest Apartments was constructed. It is a modest residential building of the Post War Deco style of architecture.) This building's front façade is composed of a single block massing mixed with brick panels which are uncommon for the mainly stucco-fabric facades at Ocean Drive. Also in 1948, the Pelican Hotel was built at 826 Ocean Drive. (Figure 34) Henry Hohauser was the architect of the project. This building is not considered historic and not even contributing. It has not registered in the Planning Department within any specific style of architecture. Its only considerations are that it is conforming in scale and stylistic features. The scale refers to proportions and mainly the height of the building, which is $40 \mathrm{ft}$ for a three-story building. The stylistic features that are in accordance or conforming to the urban typology or fabric refer to the skin of the building, made of stucco and to such urban features as the front terrace and baluster rail rounding the terrace at the entrance.

In 1950, the Boulevard was constructed at 740 Ocean Drive. (Figure 35) It was originally called the Bolivar Hotel and was designed by August Swartz. It is a three story, $37 \mathrm{ft}$ high building. The building conforms in scale and stylistic features to the Historic District. It has a front porch with a stone veneer on the ground floor and a facade made of stucco and stone. It suffered substantial alterations in 1989 , including the creation of an atrium. 60

In 1950, the Adrian apartment house was constructed at 1052 Ocean Drive. The architect for the project was T.M. Sherman. (Figure 36) This two story, 20ft high building is conforming in scale, setting and stylistic features according to the Planning and Preservation Department of the City of Miami Beach. It contains a shallow front terrace with a railing. It was first a residential building and now is a commercial building. ${ }^{61}$ It has a commercial storefront at the ground floor (Tattoo) and has no significant features on the interior of the building. Also in 1950, the Revere Hotel was built at 


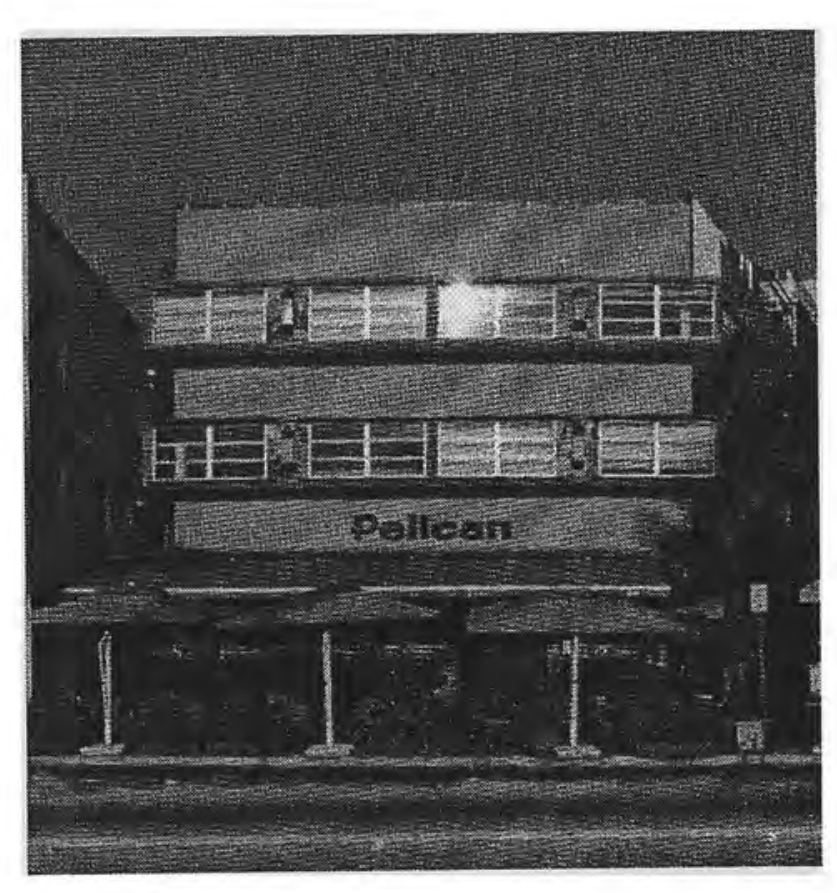

Fig. 34

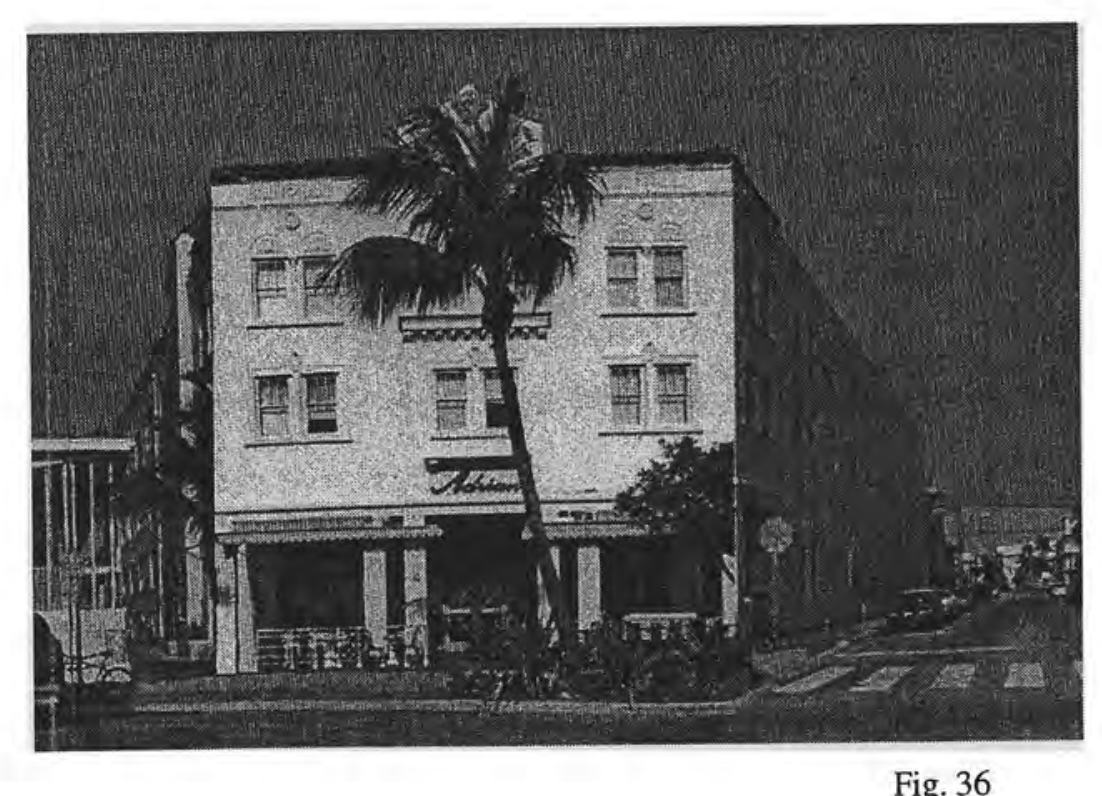

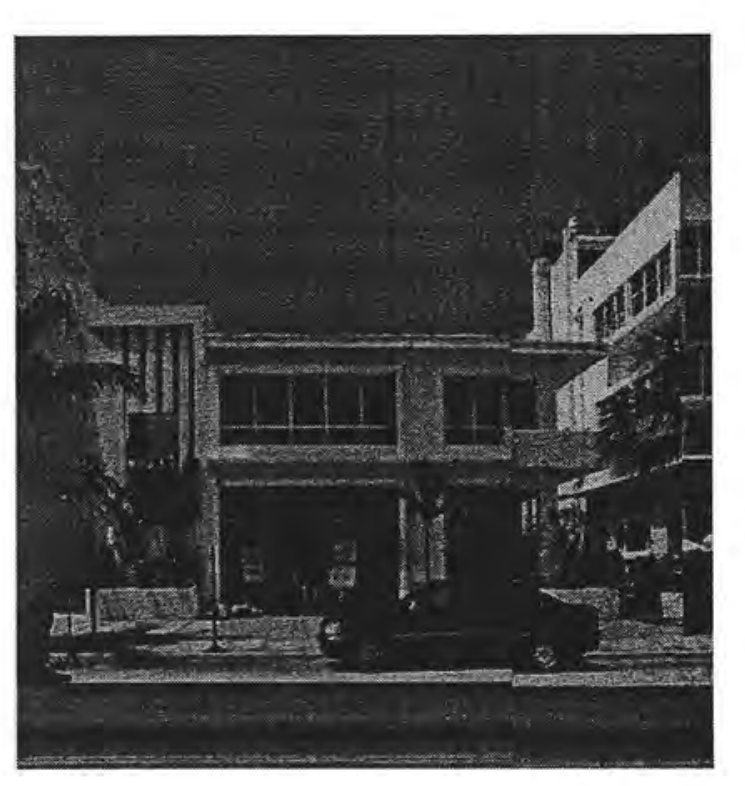

Fig. 37 
Masonry and brick details on its main façade facing the ocean. ${ }^{66}$ This building is in process of re-opening with severe alterations made to its architecture.

In 1958, the Sun Haven apartment building was constructed at 800 Ocean Drive. It is three stories, $33^{\prime} 9^{\prime \prime}$ building designed by Gibert Fein. It is also considered non historic but conforming and its main features are that it is located at a corner site between $8^{\text {th }}$ Street and the ocean and has a front porch with a continuous pierced masonry railing in the ground floor, 2nd, $3^{\text {rd }}$ stories, and roof.67 (Figure 39)

At 844 Ocean Drive lies the Casa Grande Suite Hotel designed by Gilbert Fein and constructed in 1958. (Figure 40) It is a three story, $34 \mathrm{ft}$ high building designated as nonhistoric but conforming. It is attached to 834 Ocean Drive.68 It has a colonial style of tile roofing and at the ground floor lays the Mezzaluna restaurant.

Finally, also in 1958, the White House Apartments were constructed at 1446 Ocean Drive. (Figure 41) Architect Reif designed this three story, $31 \mathrm{ft}$ building in a Garden style of architecture. This building is designated as non-historic but conforming in scale. Its architectural features are its brick veneer and decorative wood railings. The exterior fabric of the façades is made of stucco. ${ }^{69}$
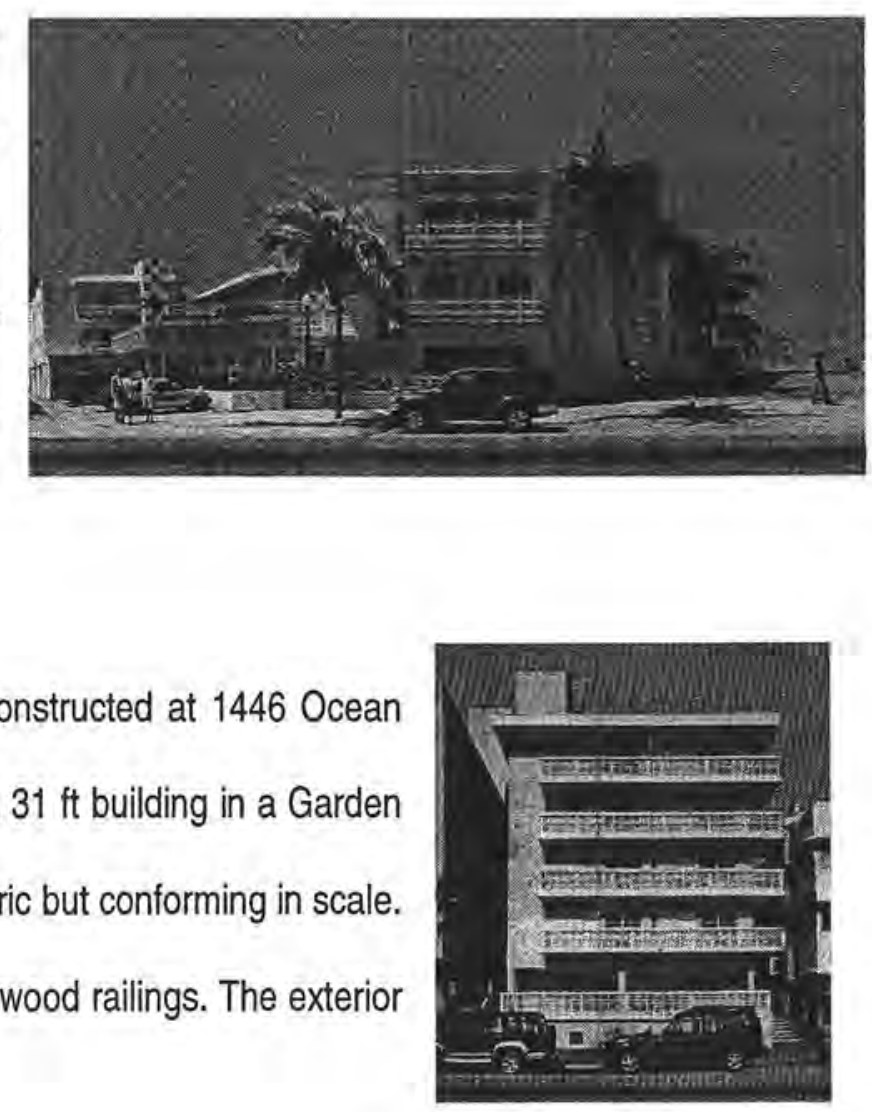

${ }^{66}$ Miami Beach Planning Department Building Cards - Ocean Drive ${ }^{67}$ Ibid.
In 1961, a Post World War II Transitional, Post Art Deco residential building was constructed at 158 Ocean Drive. Architect Maurice Weintraub designed this residential condominium designated as contributing by the Preservation Department. In 1964, the Ben-Stan Apartments building was constructed at 1024 Ocean Drive. (Figure 42) The five story, 49ft high building was designed by J. Meyer. It is considered non historic and does not conform to the Historic District. This building front façade is made of stucco and brick with continuous masonry balcony rail. This building front terrace is raised from the sidewalk level, higher than the regulations and standards for Ocean Drive.70

In 1969, at 401 Ocean Drive, the Presidential Condominium apartment building was constructed. The architects responsible for the project are Frese-Camner Associates. It is an 11 story, 96ft high building located in the Ocean Beach Historic District. The building includes parking for 161 vehicles. On October of 1968, the Miami Beach City Council approved its construction with the condition that no commercial business would occur in this property. ${ }^{71}$ Also before the actual construction of the building, the City Council approved the extension of fourth street pavement eastward from Ocean Drive. This building is considered non historic and not conforming by the Preservation Department. Also in 1969, the Ocean Point condo-apartment building was constructed at 345 Ocean Drive. The architects were also Frese-Camner Associates. This was a very similar project to the one on 401 Ocean Drive. The height of this building is $107 \mathrm{ft}$ for seven stories of 238 apartment units. There are 160 automobile parking spaces and a $15^{\prime}$ extension of the building eastwards into the setback on the Oceanside. Also, this regulation changed were approved by the City Council with the condition that there would be no commercial business on this property. ${ }^{72}$

The City of Miami Beach Planning and Preservation Department considered none of the buildings of this Post War era Historic. During this period of time, 16 buildings were constructed on Ocean Drive. At most they contain some architectural features that are considered significant or conforming. Most of these buildings maintain a conforming scale in accordance to the standards and regulations established for Ocean Drive and the Historic District. 
During this period of time the large-scale tourism and construction of big hotels occurred at the North of Ocean Drive The Fountainbleau Hotel and the Eden Roc are some of the buildings constructed during those years. During the late 1960's to the 1980's there was little new development at the heart of Ocean Drive, which extends from $5^{\text {th }}$ Street to $14^{\text {th }}$ Street. (Figure 43) After the war, affluence and tourism came back to Miami Beach, but not to Ocean Drive and South Beach. The smaller hotels became outdated and gave way to the bigger hotels to the north. ${ }^{73}$

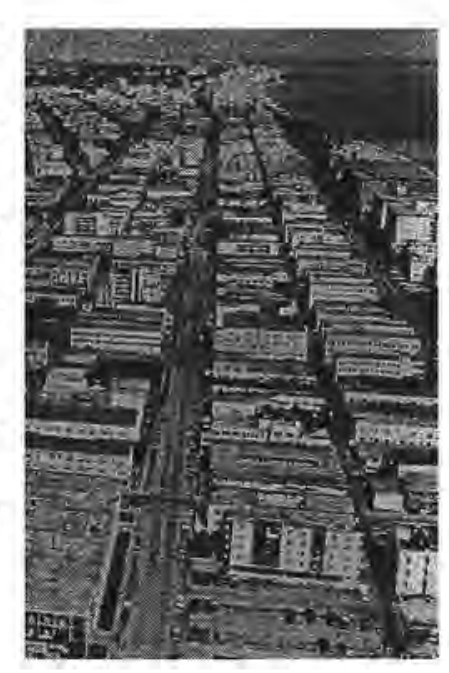

\section{0s-1990s}

The Miami Design Preservation League was founded in June of 1976, in an attempt to revive the area along South Beach. Three years later, the National Register of Historic Places designated the Historic District in 1979. In 1986, the Miami Beach City Commission, composed of a staff including members from the Planning, Design and Historic Preservation Division, created two minor districts within the larger Historic District. One includes Espanola Way, a narrow, six block lane of tile-roofed buildings. The second includes Ocean Drive from $5^{\text {th }}$ Street to $15^{\text {th }}$ Street and Collins Avenue from $6^{\text {th }}$ to $16^{\text {th }}$ Street. The National Register Architectural District or the Historic Art Deco District is divided into minor districts which include Espanola Way Historic District, the Ocean Drive/Collins Avenue Historic
In 1989, a new zoning code was established for the City of Miami Beach. This code allowed a number of big new convention hotels to be built along District, north of South Beach, in exchange for protection of the rest of the district. Also, this new zoning allowed properties along the Historic District to have commercial uses in previously residential and hotel areas. This new "hotel village" plan as was called by preservationists of the time, allowed historic properties to have their facades stripped and changed into trendy shops and alternative uses. The new zoning ordinance allowed the development of today's Loews Hotel at Collins Avenue. However, after the ordinance, many historic buildings were demolished to let the new construction to be built. The Boulevard, Carl Fisher's last hotel, The New Yorker, and The Rock Garden Hotel, are some of the buildings demolished during the time despite the opposition of Barbara Capitman and the MDPL.

The new zoning ordinance of 1989 , led to the commercialization of Ocean Drive that has flourished since then. Leonard Horowitz, a former MDPL member and preservationist whose name has been given to $11^{\text {th }}$ Street in Miami Beach, stated in an interview in 1988: "We need to preserve every building that we have because what we're preserving is the streetscape, not just the building, and the fact that they're together-their integrity of design." ${ }^{\prime 4}$ At the beginning of the 1990 s, there was a big hit to the preservation movement with the new zoning plan and new construction project to be developed. Also, in 1990, Mrs. Barbara Capitman died at the age of seventy. District and the Museum Historic District, which starts at $17^{\text {th }}$ streets and ends in the Collins Canal.

Also in 1976, the commission approved a new set of zoning changes designed to encourage renovations of dilapidated buildings on Ocean Drive and Collins Avenue. In exchange for restoring buildings, owners would be allowed to change residential spaces to commercial and retail spaces.

In 1990, the Ocean Promenade was built at 1040 Ocean Drive. (Figure 44) The architect of the project is W. Osborn. It is a non-historic building and is considered compatible with the Historic District and MXE zoning. ${ }^{75}$ This is a two-story building with an open-air bar and a canopy over a concrete paved floor. As a result of the 1989 ordinance, commercial activity exploded in Ocean Drive during the 1990s, producing the highly commercial environment that is present today. This encouraged investors to develop high-rise structures along Miami Beach.

${ }^{74}$ A pastel Paradise, Video by Levien Products, Inc. Miami Beach, Fl. 1988.

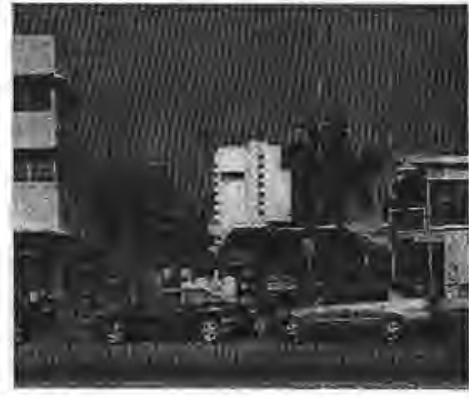

${ }_{73}$ Shulman, Allan. CiudadCity. COAVAN, 2000.p.31 
In 1998, II Villagio Condominium was built at 1455 Ocean Drive. (Figure 45) It is a sixteen story mixed use edifice, overlooking Lummus Park and expansive white sand beach. At the northern border of Ocean Drive, facing the Ocean and $15^{\text {th }}$ street, lies 1500 Ocean Drive. (Figure 46) It is a fifteen story beachfront condominium that is in the process of completion. The internationally known architect Michael Graves designed this building. The project site is located on a narrow 2.5-acre rectangle that stretches from Collins Avenue to the beach and terminates the view north along Ocean Drive. In the project development, the City requested the preservation of the four-story Bancroft Hotel, a 1939 historic structure occupying part of the property. Finally, only the wrapping of the Bancroft Hotel was maintained as part of the retail space of the building.

In the mid 1990s, the City of Miami Beach Planning, Design and Historic Preservation Division approved new regulations for Miami Beach. The City Commission composed of Sy

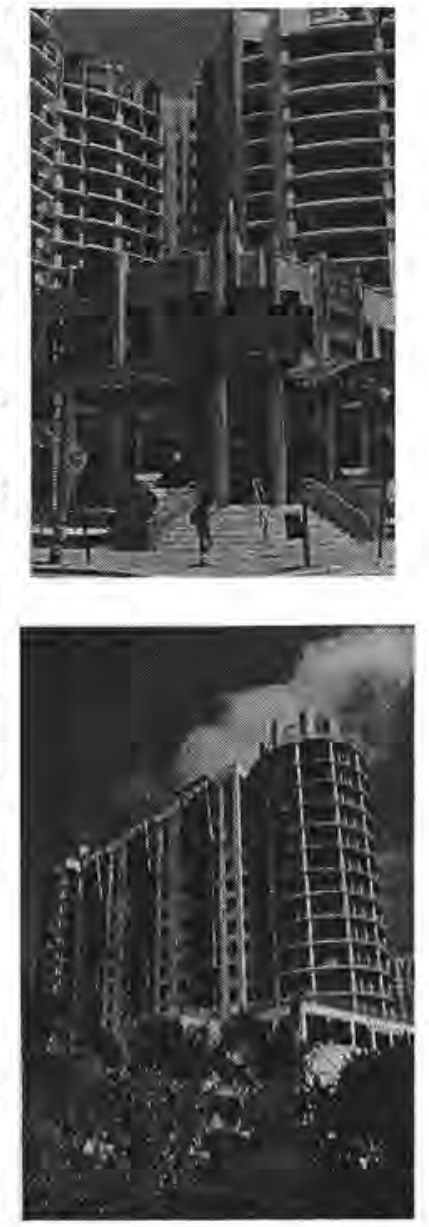

Eisenberg, Neisin O. Kasdin, Nancy Liebman, David T. Pearlson and Martin Shapiro, were responsible for the designation of the Ocean Beach Historic District. ${ }^{76}$ This district represents the area south of $6^{\text {th }}$ Street in Miami Beach. This area is not part of the original Historic District. As part of the designation report in 1995, it was stated that the proposed new district represented a significant part of the first settlement on Miami Beach, becoming a magnet for pioneer tourists and adventurous residents. It was also the site of the first subdivision and infrastructure on the Beach, known as Ocean Beach subdivision platted in 1912.77

During the last decades, Miami Beach has emerged as a global center for fashion, film, television, music, new media and the performing and visual arts. Today, Miami Beach is a mix of many diverse neighborhoods: residential,

${ }_{76}^{76}$ City of Miami Beach Planning, Design and Historic Preservation Division. Ocean Beach Historic District Designation Report. 1995. ${ }_{7}$ lbid. p.3. commercial and hotel areas are often mixed together in various unified neighborhoods. During the 1990 s, the new highrise developments on Ocean Drive are the more significant urban and architectonic developments in the area.

Construction and building activity has increased in Miami Beach during the last decade. In fact, over $\$ 1$ billion was invested in new construction and renovation of residential property during the 1990's. There is little available area for new developments along Ocean Drive. However, the renewed interest in Miami Beach real estate, combined with the rebirth of South Beach as an international playground, led to a more than doubling of the value of taxable property in the city between 1984 and 1999.78

In programming and developing a new project within the historic context of Ocean Drive, it is important to analyze the geographic location, the social, political and economical conditions of the community and the existing architecture within its different styles.

\section{Site \& Climate}

The location for the project studied in this context for a museum, is on Ocean Drive Geographic location is important to every development, but is highlighted in this project because of the special characteristics involving this location. Ocean Drive faces the Atlantic Ocean, extending from $1^{\text {st }}$ Street to $15^{\text {th }}$ Street. Its location boundaries are visibly defined by the 1500 Ocean Drive Condominium, on the north side and soon by the Bentley Hotel tower that is being built on the south. Ocean Drive is located in front of Lummus Park and the Atlantic Ocean, in the area popularly known worldwide as South Beach. An Ocean Drive site location involves very different aspects. First, its proximity to the ocean requires special conditions for foundations and structure. The South Florida Building Code, adopted since 195779, and substantially edited after Hurricane Andrew in 1992, provides the regulations and standards required for structures located at the oceanfront. Steel reinforcements within concrete footings around the perimeter of a building and steel 
bars tied to the slab foundation are some of the requirements for building in Ocean Drive. Also, steel rods must be installed around the top of the walls, with reinforcements tied from the top beam to the slab. ${ }^{80}$ Concrete piles as foundation systems are recommended for buildings with more than two floors. Many of the tall buildings in Ocean Drive such as the Presidential, were constructed using concrete piles as foundation. In the proposed restoration of the Brown's Hotel at 112 Ocean Drive, the group of architects, engineers and developers are proposing moving the building in order to build a concrete pile foundation system for the building. Ocean Drive is very susceptible to Hurricane strikes. Consequently, Dade County has had one of the toughest codes for hurricane winds in the country, and the strictest in the state of Florida.

The hurricane of 1926 caused a lot of damage and more recently; Hurricane Andrew in 1992 hit the coasts of Miami causing great losses for the city. According to National Hurricane Center, 57 hurricanes have hit directly the coastline of the state of Florida from 1990 to 1996. Twenty-four of the hurricanes had been considered category 3 or above which are considered major hurricanes. ${ }^{81}$ (Hurricane categories range from 1 to 5 ) On the other side, Ocean Drive and Miami Beach average 240 days of sunshine annually, with an average yearly temperature of 75 degrees, including temperatures averaging 68 degrees in the winter and 81 degrees in the summer. 82

\section{Social Context}

The development of Miami Beach was closely related to the development of a community in the area. Ocean Drive and Miami Beach started as part of a coconut and avocado plantation in the end of the 1800's and early 1900's. Later in the in the1920s, Ocean Drive became the winter beach resort of choice for the wealthy people of northern U.S.A. During the 1930 s and into the 1940's Ocean Drive became gradually, a beach resort for the middle class. Avoiding social discrimination along other resort areas, mainly Jewish communities and elderly people lived in the area of Ocean Drive and South Beach, through the 1940's. During World War II, soldier training took place in Miami, and Ocean Drive hotels

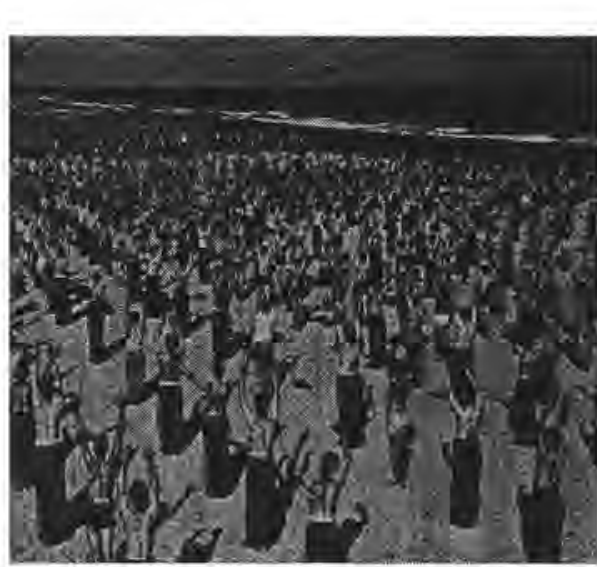

became the home to the soldiers. (Figure 47) After the War, the soldiers returned to live in Miami, and Ocean Drive. In 1980, more than 12,000 Cubans sailed north to Florida from Mariel.,83 After landing in Key West, they went directly to Miami. Many of these people were political opponents of Fidel Castro and most were Cuba's misfits and most hardened criminals. ${ }^{84}$ Later in the 1980s, during the same decade that brought the Mariel boatlift to Miami Beach, Art Deco Revival became successful, and with it, the revival of all Miami Beach. "Miami Beach had all ingredients to create one of the most distinctive urban environments in America: The architecture, the geographic location, the people. Miami Beach could be a vibrant community where all kinds of people-elderly retirees, young artists, people from the North, people from Latin American come together to create an exciting, harmonious community." 85

\section{Preservationists vs. Investors}

In the early 1980's, the renovation of the Cardozo Hotel located in Ocean Drive and $13^{\text {th }}$ street, launched the preservation movement of renovating and restoring Deco Hotels and buildings in Ocean Drive. ${ }^{86}$ The restoration of the project attracted young people, business people and trendsetters of the preservation, architectural and design communities. Later in the decade and into the 1990 's, battles between preservationists and investors dominated the Miami scene. The destruction and demolition of several hotels and the restoration of many others were among the significant events of that decade.

In 1992 Gianni Versace paid 2.95 million dollars for a historic but dilapidated apartment building known as the Amsterdam Palace, on Ocean Drive and $11^{\text {th }}$ Street. Later, he also bought the historic Revere Hotel to create a swimming pool and parking garage for his mansion. The demolition of the Revere Hotel created a battle among MDPL preservationists, Versace attorneys and city officials. In the end, the demolition of the Revere Hotel was approved. It

${ }^{83}$ Michael Raley. Old Miami Beach. Miami Design Preservation League, 1994. p. 149 ${ }^{84}$ ibid. 
was stated that the cause of the demolition was that the Revere Hotel was a non-historic building constructed after 1950. This designation belonged to the City of Miami Beach Preservation Department since the National Register of Historic Places had designated the Revere Hotel as significant since 1979. It is just one example of the many confrontations among preservationists, investors, and city officials that characterized this period. This occurrence also resulted in the conversion of half of an entire block of the most expensive real estate in Miami Beach into a private residence, approved by city officials. (Historic Preservation Board and City Planning Department)

The new Zoning Ordinance of 1989 brought a series of controversial issues. It allowed the construction of New Convention Center Hotels and changed the zoning plan for Miami Beach. The Mixed-Use Entertainment (MXE) zoning, established in that year, encouraged sidewalk cafes, and clubs which brought new residents to the city. The Historic District was called The Entertainment District, ironically. "A level of noise and discomfort that could kill the goose that laid the golden egg." ${ }^{\text {87 }}$ According to many preservationists of the time, the new ordinance would lead to the destruction of The Art Deco District. Critics of the ordinance worried that the new hotels would cast shadows over the Historic District and the new zoning would cause a change in the urban context and demolition of many historic buildings. After the new zoning Ordinance was established, Mrs. Barbara Capitman (Figure 48) stated her opinion to a reporter

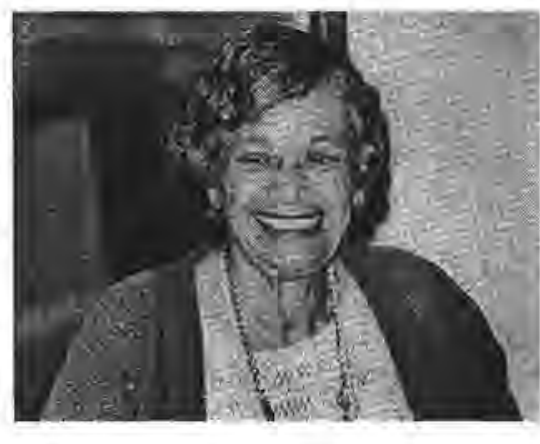

of the Miami Herald: "I have this awful feeling, from experience, I sense this mood to relax and compromise, this of self-complacency. It's such a scary thing. I can see the whole Art Deco District being gone in two years." ${ }^{" 88}$

\section{Economic Viability}

Another point of extreme importance when programming an architectonic development, are the economic issues. "Resort tax collections are the one true indication of business on Miami Beach," said Stuart Blumberg, director of Miami

\section{5
${ }_{86}$ T. D Allman, Miami City of The Future. New York: Atlantic Monthly Press, 1987. $38-39$
Michael Bal ay Old Miami Beach. Miami Design Presenvation League, 1994. P. 99.}

${ }^{86}$ Michael Raley. Old Miami Beach. Miami Design Preservation League, 1994, P. 99.

${ }^{88}$ Charles Whited, "Art Deco's Grande Dame Fought to the End," Miami Herald 1 April 1990.
Beach Resort Hotel Association. In recent years, resort tax revenue has gone up 20\%. Ocean Drive shows the fastest increases in tax revenues including food \& beverage tax. In fact, in municipal Miami Beach, the primary source of income is tax revenues. Ocean Drive has the highest taxes within Miami Beach. These statistics, gathered from surveys done by the MDPL, show the high economic value of any piece of land in Ocean Drive. Showtime Interactive website offers a questionnaire on South Beach. The question is: "Visited South Beach? What's its best feature? The results by May 2000 are: Bars and Clubs 48\%, Overall atmosphere $29 \%$, Restaurants $6 \%$, Shopping $3 \%$ and Location $2 \%$.

Construction and building activity continues to increase throughout the City of Miami Beach, at the beginning of the new millennium. In fact, over $\$ 1$ billion was invested in new construction and renovation of residential property during the 1990's. This interest in Miami Beach real estate, combined with the rebirth of South Beach as an international playground, led to a more than doubling of the value of taxable property in the city between 1984 and 1999.89

Condominium sales at the end of 1998 were up $28 \%$, however, inventory also increased almost $10 \%$ during that time. Construction of upscale condominium projects was higher, increasing the inventory of condos priced $\$ 500,000$ and higher by $87 \%$. These numbers are in accordance to the development of the new high-rise condominiums in northern Ocean Drive. The South Beach market is primarily a non-resident market with close to $70 \%$ unoccupied in the off-season, as in the case of the II Villagio Condominium. These statistics are important since they show the increase of commercial activity in the already very commercialized environment of South Beach. They also show that new residential developments as the high-rise condominiums on northern Ocean Drive could hardly occur in a near future along Ocean Drive. ${ }^{90}$ 


\section{Architectural Character}

On Ocean Drive there are currently sixty-nine private buildings and two public buildings (on Lummus Park). According to documentation done by the city of Miami Beach Planning, Design and Historic Preservation Division in 1995, architectural styles within Ocean Drive vary according to architectural tendencies and typologies of the 1900's.

Architecture on Ocean Drive as part of the Historic Art Deco District marks its beauty and success in its collective architectural and urban qualities. On Ocean Drive, a single contributing building may not seem to possess a specia significance when viewed by itself, but when viewed together with its neighboring buildings, a unified image of a distinct and attractive neighborhood occurs, contributing to the special character of the community's urban fabric. A larg number of contributing buildings reflective of different architectural typologies and development patterns from the early days of Miami Beach to the present era characterize Ocean Drive. The survival of Ocean Drive architecture depends on a compatible, harmonious and supportive environment in the future, which promotes sensitively, designed new projects New developments with sensitivity to the unique aesthetic character of the area and respect for its early origins can contribute to the architectural identity of Ocean Drive. Buildings, old and new, are usually the major defining elements in the makeup of a neighborhood character. This character is what gives identity to a historic district. The special character of a neighborhood can be maintained and reinforced by highlighting and preserving the significant architectural features of the buildings that are considered to be contributing to the area and by being considerate of those special qualities, in the design of new construction.

\section{Historic Contexts}

In order to design a project within a historic area, it is important to understand the meaning of historic context. Analyzing different developments within historic areas can provide patterns for development or determine different ways in which a project can confront the conditions of a historic location. The first historic district in the United States was established in
1931 at Charleston, South Carolina. ${ }^{91}$ Today there are many historic districts in America and around the world. Some examples of historic areas include the French Quarter (the Vieux Carre section) in New Orleans, the second oldest historic district in America, established in 1936, Coney Island in New York or Greenwich Village also in New York.

Greenwich village for example, is composed of a small-scale group of neighborhoods with buildings, mostly below six floors in height. The styles of architecture within the area vary from Greek revival architecture to Gothic Revival Architecture. However, it is the human scale and character of the place that provides an integration or continuity. "When speak of Greenwich Village I have no geographical conception in view. The term Greenwich Village is to me a spiritual zone of mind.... The city, which hasn't a Greenwich Village, is to be pitied. It has no life, no illusion, and no art."92 Greenwich Village symbolizes the idea of intellectual freedom of thought and expression. Greenwich Village is a home neighborhood for New York University, where people from very different cultures live together harmoniously. Greenwich Village endures as a cultural crossroad filed with a widely varying, many-textured intellectual and artistic life. (Interventions in historic areas can serve as case studies for the development of this thesis. Greenwich Village-the townhouse infill project by architects Hardy, Holzman, Pfeiffer ${ }^{93}$ )

When referring to how to design in a historic context, it is important to find a common way to address the issue. Is there a pattern for designing in a historic area? According to Vitruvius, in architecture as in life, all disciplines follow a process, "have a common bond of union and intercourse with one another". ${ }^{44}$ Architecture as any other discipline in life depends on history as a reference and principle for or towards new ideologies. When referring to designing according to a context, it is best to look at typologies or paradigms that form a definite pattern. "Paradigm is the word used to describe a disciplinary matrix, ensembles of beliefs and practices broadly shared by the members of a disciplinary community about: methodologies, purposes, values, institutional roles, society justification, pedagogic models, interpretive

${ }^{91}$ Norman Tyler. Historic Preservation. New York: W.W. Norton \& Company, 2000. p.59 ${ }_{93}^{92}$ Hippolyte Havel, The Spirit of Greenwich Village. 1915.

Norman Tyler. Historic Preservation. New York: W.W. Norton \& Company, 2000. p.59

${ }^{34}$ Raul Garcia. Arc 4993, Preservation/Architecture. Thomas Kuhn's concept of Paradigms (20" century philosopher) 
concepts, theories, domain and scale of concern or subject matter". ${ }^{95}$ Is there a pattern or definite paradigm to design within a historic context?

\section{Role of Preservation}

When referring to historic context and continuity in architecture is important to mention historic preservation, which is the basis for what is now the Art Deco District. One of the first acts of preservation in America was the successful effort to prevent the demolition of the Independence Hall or Old State House. The Mount Vernon Ladies" Association of the Union is considered the first preservation group founded in 1853 , to save the deteriorating Mount Vernon, George Washington's homestead. 96

Another important date for the preservation movement was the establishment of the National Trust for Historic Preservation in 1949. In 1966, the U.S. government approved the National Historic Preservation Act.97 This Act established the National Register of Historic Places, which is responsible for designating historic districts as the Art Deco District.

Along Ocean Drive, every structure represents the history and evolution of the City of Miami Beach and the historic Art Deco District. The early development plan of the Lummus Brothers proposed a middle class resort with a low scale typology of buildings. During the 1990s, there have been new developments that antagonized the original development plans for Ocean Drive and the southern part of Miami Beach. Also, there have been parallel movements of preserving, restoring, and rebuilding on Ocean Drive.

Since the late 1980's, Miami Beach and especially Ocean Drive has become a very popular place. It has become a center of tourism and entertainment activities. Ocean Drive became the façade for commercial advertisements, the fashion industry, and the entertainment industry in general. With this, came the success and money to promote and

${ }_{95}$ Barbara Flanagan, "Can a building change the way people see their city-and think about architecture? If the Gehry's Guggenheim is any proof, the answer is

${ }_{96}^{\text {a resounding yes!"- Metropolis magazine (April 1998) }}$ Norman Tyler. Historic Preservation. New York: W.W. Norton \& Company, 2000. p.33. restore the area. However, the money, the luxury, the glamour, also brought the risk of turning Ocean Drive away from its original conditions, a resort area for the middle class with a high diversity of ethnic population. Ironically, these concepts can also be applied to defining preservation in a commercial and superficial manner. The irony presented in describing the social environment around Ocean Drive and the concept of preserving, can help understand a false saying about preservation.

The preservation of a building not only involves its physical aspects or "looks". It involves the history of the place, and the historic events that took place in those spaces. Considering the spaces within and around the buildings, as part of their living history allows historic structures a more active and significant role within the community. Therefore, preservation should be seen as more than protection of older buildings. Preserving buildings only as inanimate structures makes of them museum pieces, objects of collection and nothing more.

During the 1990's, Tourism advertisements referred to Ocean Drive and South Beach as an American Riviera. The Beach, the nightclubs, was the reference for the advertisement. Currently, on Ocean Drive it is hard to appreciate the architecture due to the large amount of commercial and social activity taking place along, in front of the buildings that line and shape the street. Through the history of Miami Beach and Ocean Drive could be seen that "South Beach" is one of the most popular areas not only within Florida but the entire world. Its success lies in that it has a well-defined identity that is appreciated by people all around the world. At this point, it is important to take advantage of the "popularity" of Ocean Drive to enhance its architecture and the preservation of the buildings and history, which are the key elements in shaping the identity behind the commercial façade of Ocean Drive.

\section{Program}

To promote historic preservation and the history of the Art Deco District and Ocean Drive, this thesis proposes the designing of a Museum of Urban Development at 1126 Ocean Drive, between the Amsterdam Palace and the Victor Hotel. (Figure 49) The Museum of Urban Development would provide one type of architectonic and educational response to the issue of preserving a historic context.

${ }^{97}$ Norman Tyler. Historic Preservation. New York: W.W. Norton \& Company, 2000. p.33. 


\section{Museum}

The use of a museum of urban development in order to enhance a

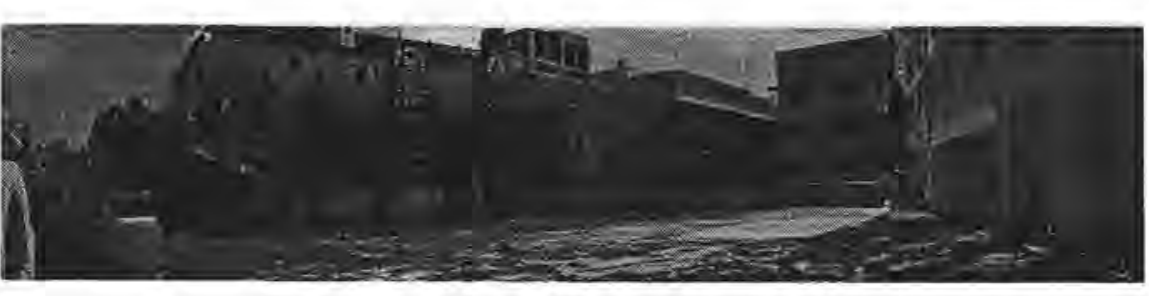

historic context can be related to other ways of preserving the history of a place or area. A House Museum, according to the National Trust, is "a museum whose structure itself is of historical or architectural significance and whose interpretation relates primarily to the building's architecture, furnishing and history." 98 By this, it could be understood that a house museum can be considered an adaptive use. This concept can relate to the case of Ocean Drive where the Ordinance of 1989 and the new zoning for the area let to historic residential buildings to adapt into commercia structures. However, this contradicts the philosophy mentioned before of preservation being more than the outside physical structure, but rather all the spaces and conditions that contribute to defining the identity and history of a place.

The House Museum is the most traditional solution to the problem of saving a historic building. However, there are also the Outdoor Museums, which stand as the second major answer to the preservation of buildings. An Outdoor Museum is defined by the National Trust as "a restored, re-created or replica village site in which several or many structures have been restored, rebuilt, or moved and whose purpose is to interpret a historical or cultural setting, period, or activity. ${ }^{n 99}$ There are three forms of Outdoor Museums. They may consist of original buildings, on their original sites, preserved and operated as a museum for educational purposes. They may also, consist of buildings of historical or aesthetic interest moved to a new site for similar purposes. Finally, they may be composed of totally reconstructed buildings built with the same educational aim in mind. The outdoor museum movement originated in Sweden. Artur Hazelius is considered the father of the outdoor museum movement, credited for creating the first outdoor museum in central Stockholm, in 1873.100

${ }^{39}$ William J. Murtagh. Keeping Time. New York: Preservation Press, John Wiley \& Sons, Inc., 1997. p. 78.
When analyzing the Art Deco District and Ocean Drive, many people can refer to it as an outdoor museum. However, the definition of the outdoor museum by the National Trust refers to a collection of historic buildings existing primarily for "educational" purposes. Educational is the keyword that separates Ocean Drive from been an outdoor museum. Ocean Drive has mainly commercial and also entertainment purposes. Can Ocean Drive then, be related to amusement parks as Disney World, where the main objective of the Victorian Street of Disney World's Hometown U.S.A. is to provide entertainment and not education.

The idea of the Museum of Urban Development is to unify all these concepts into a building within the most important street of the historic district, an icon of the preservation of the buildings and history of Ocean Drive and Miami Beach that are the real engine behind the success story of "South Beach." Among the many buildings on Ocean Drive, only two are public and they are attached to each other. There are no museums along Ocean Drive and three museums in all the area including the National Register Architectural District and the Ocean Beach Historic District.

On Washington Avenue lies the Ziff Jewish Museum of Florida, housed in a Copper-domed 1936 Art Deco building with stained glass and a marble bimah. The Building is also an Orthodox synagogue listed on the National Register of Historic Places. Exhibitions in the museum feature historical documents and artifacts. A video exhibits 230 years of Jewish life in Florida; starting from the time Jews landed with Ponce de Leon escape European anti-Semitism. ${ }^{101}$

The Bass Museum of Art, on Park Avenue, houses European paintings by the Masters, period furnishings, Hispanic and American art, and a collection of art objects, tapestries and sculptures. Finally, the Wolfsonian-FIU, on Washington Avenue, showcases some 300 objects d'art of American and European provenance from the late 19th to mid-20thcentury collection of businessman Mitchell Wolfson. Glass, ceramics, furniture, posters, memorabilia, political propaganda, rare books and sculptures can be seen. ${ }^{102}$

${ }^{100}$ William J. Murtagh. Keeping Time. New York: Preservation Press, John Wiley \& Sons, Inc., 1997. p. 93.

102 http./Www.ci.miami-beach.s.l. usindex.htm 
Museums can theoretical link the past and the present. During the last 30 years more than 600 museums have been constructed in the United States. Today, many museum designs are architectonic art pieces. The museum of the future becomes not only a place for displaying art but also an art piece in itself, as expressed in theory by Kenneth Powell in the prologue of the book New Museums, edited by Andreas C. Papadakis, or in practice by Frank Gehry in the Guggenheim in Bilbao. The Museum of Urban Development should be a place that physically showcases the architecture of the twenty-first century while it maintains the identity of Ocean Drive and the Art Deco district. It should address the context of society, of nature and history, which is acquired and expressed through the many different architectural and urban proposals and their consequences.

\section{Proposal}

The building proposal for the Museum of Urban Development and Headquarters for the Planning/Preservation Department of Miami Beach is a public facility of around 10,000 sq. feet of construction on an empty site located on Ocean Drive between the Amsterdam Palace and the Victor Hotel, between $11^{\text {th }}$ and $12^{\text {th }}$ Street. The project theory starts with the concept of generating a civic facility for public use. The program for the building originated in the concept of relating the very public Ocean Drive into an enclosed space, focusing in the relation of public and private through a semi-public, civic space. From that concept, arises the idea of programming a Museum that celebrates the city and its community.

Ocean Drive is one of the best examples of contemporary urbanism as a result of a mixed-use zoning system. Let to the idea of integrating different uses for different users, within a single program proposal. The building proposal starts at the entrance level, as a pivotal element for the program of the project. The program at that level includes an open exhibition space that traverses the site from east to west, creating a pedestrian walkway or passage, extending the sidewalk into the building. This walkway connects Ocean Drive to Ocean Court and consequently, provides for a different pedestrian connection into Collins Avenue and allows the pedestrians to experience the alley in a different context. With this, the concept of the proposal is to provide for a new use for the alley, becoming more active, proposing for a temporary pedestrian mall. The idea is to take advantage of the architectural qualities of this urban corridor. By walking through the passage or walkway inside the building proposal, the visitor experiences the transition between an open and an enclosed space, or the relation between public and private, exterior and interior. The sensation of being in a transitiona space are possible due to the scale, lighting and elements that configure the space: Different exhibition elements hanging at different levels of a $87^{\prime}$ high passage that exhibits a semi-public exhibit space, composed of architectural and sculptural elements as urban pieces, digital screens continuously projecting information and a background scenery of the north façade of the Amsterdam Palace or Versace's Mansion, popularly known today. (Figure 50)

Also at the entrance level, stands a temporary exhibition or rental space that can open and connect to the walkway. Towards the entrance facing Ocean

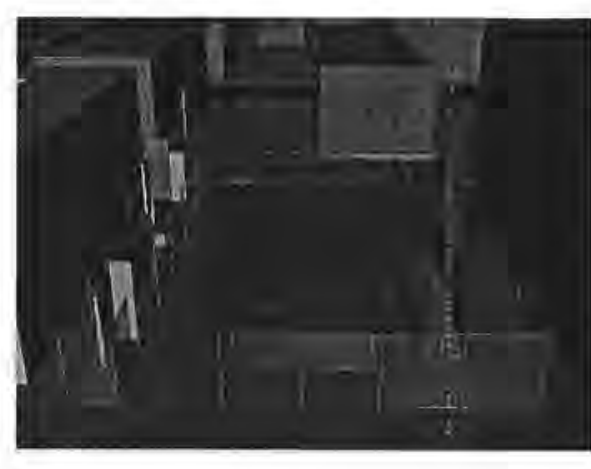
Drive, lay the vertical circulation and museum store. Facing Ocean Court lays a small movie theater that projects movies related to Ocean Drive and Miami Beach.

At the second level stand the offices for the headquarters of the Planning/Preservation Department of Miami Beach. It includes a reception desk and public attention area, a general working space and private cubicles for city planners, manager and director. At the third floor level, stand the archives for the offices of the Planning/Preservation Department. Most of the material included in this collection is held in books, newspapers, microfilms and computer databases.

At the fourth level starts the Museum of Urban Development. Most of the exhibition of the museum is experienced through images or visual elements. At this level, the main exhibition space is composed of a $1^{\prime \prime} / 16^{\prime \prime}$ scale model of all Ocean Drive, including Lummus Park, the beach and Collins-Washington Avenues from $1^{\text {st }}$ to $15^{\text {th }}$ streets. At this level ends a ramping exhibition tour that starts at the seventh level. This ramp allows the visitors to view the city as they ramp down from a $100 \mathrm{ft}$ high roof top perspective of South Beach into a 60ft high view of the city. The $10^{\prime}$-wide ramps surround the building along the east, west and southern sides. The ramps start at the fourth level, since most of 
the buildings in the Architectural District are approximately, 50ft high according to the city codes. This, allows the pedestrians to walk through the different levels of the building with the city as the focus of the viewed exhibition with different perspectives and scales. People can both see and be seen as they, walk on the sidewalks next to the buildings in South Beach. The fourth level provides information with regard to the history of Ocean Drive and the Art Deco District.

The fifth level represents the conjunction of exhibition space and the Preservation Movement. At this level, there is a void over the fourth level's architectonic model that leads to the auditorium and conference room. This double height space allows the visitors to experience the model from a different perspective. The auditorium seems to float or hang inside the main rectangular volume enclosed by the scaffolding structure conformed by the steel structure and the glass skin walls. The auditorium can be seen from most of the other internal spaces of the building and is very clear from the outside. The auditorium north and east sides are very transparent so that they can integrate into the exhibit space. The Preservation Board Meetings would serve as part of the Preservation exhibit.

The sixth level is a continuation of the previous level, focusing on architectonic details within Ocean Drive and the District.

At the seventh level stand the library and the technology research center. The area facing the Ocean is higher in order to enhance the frontal view of the Ocean. In this level starts the ramping down, as exhibition. The idea is to experience the processional urban exhibit, descending the ramp to facilitate public use. On the eighth level stands a cyber café with indoor and outdoor activity, and an open terrace facing the Atlantic Ocean.

\section{Proposal}

The building proposal for the Museum of Urban Development and Headquarters for the Planning/Preservation Department of Miami Beach is a public facility of approximately $10,000 \mathrm{sq}$. feet of construction on one of the only remaining empty lots along Ocean Drive located between the Amsterdam Palace and the Victor Hotel, which are, in turn, between $11^{\text {th }}$ and $12^{\text {th }}$ Streets. The project theory begins with the concept of generating a civic facility for public use. The program for the building originated in the desire to translate the very dynamic character of Ocean Drive to an enclosed space of somewhat limited accessibility, focusing on the resulting tension between public and private space on Ocean Drive through the creation of a semi-public civic space for the District. From that concept, arises the idea of programming a Museum that celebrates the city and its community.

Ocean Drive is one of the best examples of contemporary urbanism as a result of a mixed-use zoning system that allows the integration of different uses and different user groups, within a single building proposal. The Museum proposal introduces itself to the street and the city at the ground level, as a pivotal element for the program of the project. The program on the ground floor includes an open exhibition

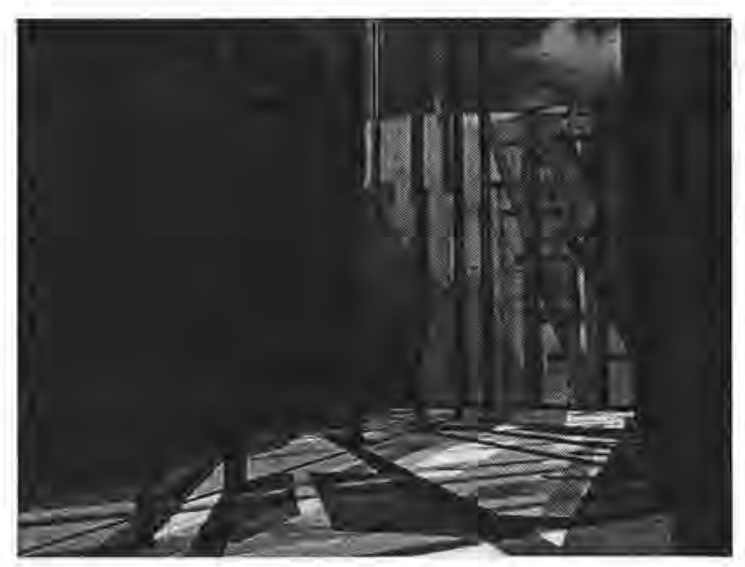
space that traverses the site from east to west, creating a pedestrian passage open 24 hours per day which extends the sidewalk into the building, and connects Ocean Drive to the alley behind it, named Ocean Court. Consequently, the building provides for a different pedestrian connection to Collins Avenue from the mid-block between $11^{\text {th }}$ and 12 Streets and allows pedestrians to experience the alley in a different context. (Figure 51) With this, the proposal provides a new use for the alley, allowing it to become more active, and proposing that the Museum itself operate as a temporary pedestrian mall. The idea is to take advantage of the architectural qualities of this urban east/ west corridor. By walking through the always-accessible passage inside the building, the visitor questions the accepted relation between public and private, exterior and interior spaces. The sensation of being in a transitional space is made possible by the scale, lighting and related elements that configure the space: Different exhibition elements hanging at different levels of an $87^{\prime}$ high passage that houses a semi-public exhibition space, composed of architectural and sculptural elements, and digital screens continuously projecting information, all the context of the north façade of the Amsterdam Palace (or Versace's Mansion, as it is popularly known today) visible as backdrop through the glass envelope of the Museum. 
Also at the entrance level, is a temporary exhibition or rental space that can open and connect to the east/ west passage. Towards the entrance facing Ocean Drive, lie the vertical circulation and museum store. Facing Ocean Court is a small movie theater that projects movies related to Ocean Drive and Miami Beach.

At the second level are the offices for the headquarters of the Planning/Preservation Department of Miami Beach. This space includes a reception desk and public attention area, a general working space and private cubicles for city planners, manager and director. At the third floor level, the archives for the offices of the Planning/Preservation Department can be found. Most of the material included in this collection is held in the form of books, newspapers, microfilms and computer databases.

At the fourth level the public exhibits of the Museum of Urban Development begin. Most of the exhibition is experienced through images or visual elements. At this level, the main exhibition space is comprised of a $11 / 16^{\prime \prime}$ scale model of all Ocean Drive in the year 1950, including Lummus Park, the beach and Collins-Washington Avenues from $1^{\text {st }}$ to $15^{\text {th }}$ streets. The mode is $50 \mathrm{ft} . \times 16 \mathrm{ft}$. in dimension. Visitors are invited to walk around it in order to

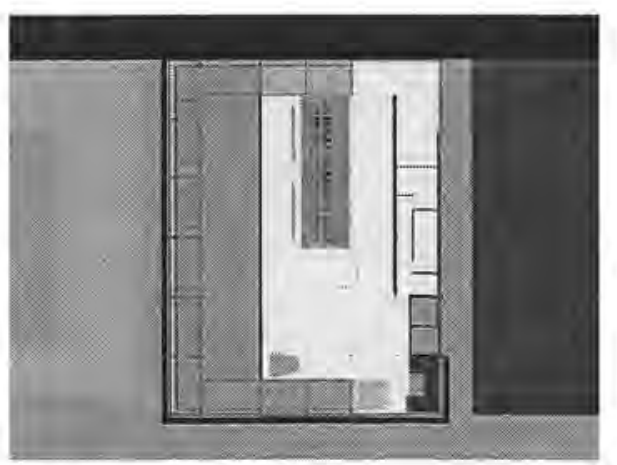
understand the urban structure of the eastern border of Miami Beach. (Figure 52)

A ramping exhibition tour of the city and museum holdings that begins at the seventh level both begins and ends on the fourth floor in front of the architectural model. This ramp allows the visitor to view the city as he descends from a $100 \mathrm{ft}$ high roof top perspective of South Beach to a $60 \mathrm{ft}$ high view of the city. The $10^{\prime}$-wide ramps surround the building along the east, west and southern sides. The ramps end at the fourth level, since most of the buildings in the Architectural District are approximately, 50ft high according to the city codes. This allows the pedestrians to walk through the different levels of the building with the larger city as the backdrop to the viewed exhibition, and provides visitors with an opportunity to understand the city from different perspectives and scales. Simultaneously, people can both see and be seen as they walk on the sidewalks next to the buildings on Ocean Drive, and on the ramps that move visitors along the periphery of the Museum. This fourth level provides information with regard to the history of Ocean Drive and the Art Deco District.

The fifth level represents the conjunction of exhibition space and the processes of the Preservation Movement. Here, a void extends from the architectural model of the fourth level to the auditorium and conference room of the fifth floor. This double height space allows visitors to experience the model from a different perspective, while connecting the experiences of visitors to the museum to attendees Preservation Board meetings. The auditorium in which these meetings take place appears to float inside the larger rectangular volume of the Museum. That volume is enclosed by steel scaffolding structure and glass skin/ walls. The auditorium can be seen from most of the other internal spaces of the building and is very clearly visible from the outside. Its north and east sides are very transparent so that they can become integrated with the exhibit space. The Preservation Board meetings, when in session, would become a living part of the museum exhibit -an opportunity to see preservation at work.

The sixth level of the museum is a continuation of the fifth, allowing visitors on the ramped promenade to focus on architectonic details within Ocean Drive and the District.

At the seventh level stand the library and the technology research center. In order to enhance the frontal impact of the Atlantic, this research area is housed in a taller volume. This seventh level begins the downward promenade. Like in FL Wright's Guggenheim, the visitor to this museum will arrive at the seventh floor by means of an elevator, and gradually descend to the fourth level by means of a spiraling processional urban exhibit that facilitates public use. Finally, on the eighth level stands a cyber café with indoor and outdoor seating and an open terrace facing the Atlantic Ocean. 
The rectlinear shape of the building accommodates itself to the urban geometry of the site and context. Code regulations, setbacks and site conditions with regard to a limited surface and extensive program for a civic facility, led to the decision to maximize the square footage of the site.

On the outside, facing Lummus Park and the Atlantic Ocean, lies on the main façade, a 1000sq.ft. digital screen that projects images. The screen works as an urban element trying to incorporate the park as an interactive urban space that integrates to the social activity on Ocean Drive sidewalk. People would be sitting on the park, looking at the different images that would be projected from the building.(Figure 53)

The project proposal introduces a new building into the historic Ocean Drive context. It consists of a glass box that wraps a scaffolding structure and proposes to be understood as a transitional element, within a context of cohesive architectural structures. The scaffolding structure and glass express the present in the architectural continuum of the District, trying to understand how to preserve without copying. The transparency and the reflectivity of the glass enhance and sometimes mirror the surrounding architecture.

Existing architecture on Ocean Drive integrates public exterior space and interior spaces through its typology of architecture. How to address the issue of relating exterior and interior spaces, the surrounding Art Deco architecture with the social activity on Ocean Drive, into a $21^{\text {st }}$ century building, is one of the principal questions of the project proposal, A transparent building, within a light structure was the response to designing in this historic context.

\section{The Skin and Structure}

The building transparency, through its glass enclosure and structure, is a key element in relating the inside and outside. The pedestrian is invited into the building visually through the transparency of the structure, creating a strong relationship between the exterior and interior spaces. From the exterior, any pedestrian can see different activities taking place inside the building. On the other hand, any person inside the building can have an outside perspective from the interior. Any visitor can experience activities within the building, with total relation to the immediate exterior context.

Also, the glazing provides for a transparency that allows better views of the Architectural District and the entire historic context. And the transparency of the glass allows neighboring buildings, such as the Amsterdam Palace, to become an integral part of the museum. The glazed façade makes it possible for the museum to disappear, as the neighboring structures become its outside skin in the eyes of the visitor. The different layers of materials that compose the structure of the building also determine its transparency. The sunlight projected on the main façade in the morning, determines the way that the building looks. Transparency levels, according to lighting, shadows, reflection and pedestrian activity, affect the overall image of the building. In a similar manner, people and weather affect the activity and image of Ocean Drive.

The transparency of the glass provides for a metaphoric eroticism that could also be described as a key part of the social activity that takes place on Ocean Drive. The building exhibits its interior, its steel structure, creating a sense of exhibitionism that could also be related to the people walking in a fashionable manner along Ocean Drive. The museum allows for voyeurism, and in so doing relates to an eroticism that is key to the genius loci of South Beach.

Steel, as the main structural material for the building proposal and scaffolding structure, accommodates to the functional needs of the museum, allowing longer spans between columns and providing for a lighter structure. (Figure 54) The steel structure is also transparent, in the sense that it is very honest, rational and 
direct. This can relate to the way in which existing Ocean Drive architectural typologies let the exterior façade of the buildings be very frank and direct about the interior features of those buildings, creating a transparency even within the massiveness of the buildings.

\section{Architectural details and Zoning}

Continuous eyebrows along the building exterior are part of the language of the project. These eyebrows help to define levels within the building, serve as shading devices for lighting control, and integrate with the typology of the architecture of the Art Deco movement on Ocean Drive. The horizontal and continuous use of eyebrows creates continuity within the buildings along Ocean Drive.

The project proposal matches the height of the Victor Hotel immediately to the north. It diminishes its height towards the Amsterdam Palace, creating a visual balance and to integrating the building to the context. On Ocean Drive there is a pattern of construction height that is broken at continuous intervals by buildings rising more than 100ft in height. In the case of the Netherland and Tides Hotels, for example, they occupy more than one lot of $50 \mathrm{ft}$ by $130 \mathrm{ft}$ and so, tend to look shorter. In the case of the Victor Hotel, the eight story high section of the building lies within a lot of 50 by 130 feet. The Victor Hotel looks taller and narrower than these earlier structures and does not match the rhythmical pattern of height and proportions of the Ocean Drive façade. The project proposal of the Museum not only matches the existing skyline, but also integrates functionally and visually with the Victor Hotel, creating a continuous silhouette that, in concert with its neighbor, works to match the proportions of other tall buildings such as the Tides Hotel.

Most of the buildings along Ocean Drive were built along a 20-year span and according to specific social and economic conditions that influenced directly in the outcome of the architecture developed. This project proposal responds to the social, architectonic and economic needs of the present times by providing a contemporary structure that allows contemporary concerns such as views and public and semi public spaces, to be a priority in the context of the building.

The building is harmonious with its surroundings despite its contrasting architectonic language to the myriad styles of architecture along Ocean Drive. The project generates continuity as it responds to the needs of its time in the same manner that the buildings of the Art Deco movement responded to the needs of the first half of the $20^{\text {th }}$ century. The purpose of the building is to reflect, to celebrate the surrounding architecture, and not to copy it. Here contras enhances the invaluable historic context. 

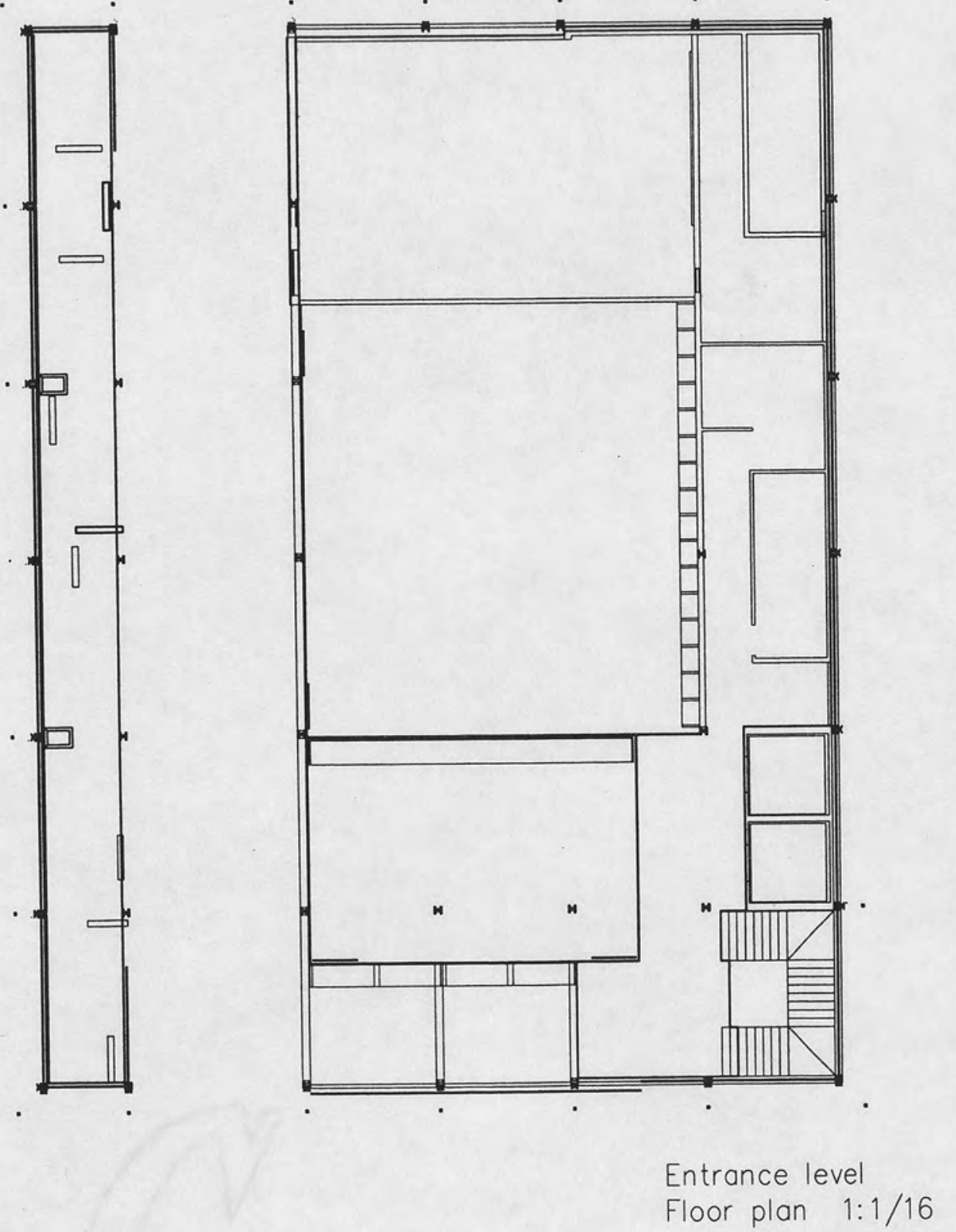

$\ominus$

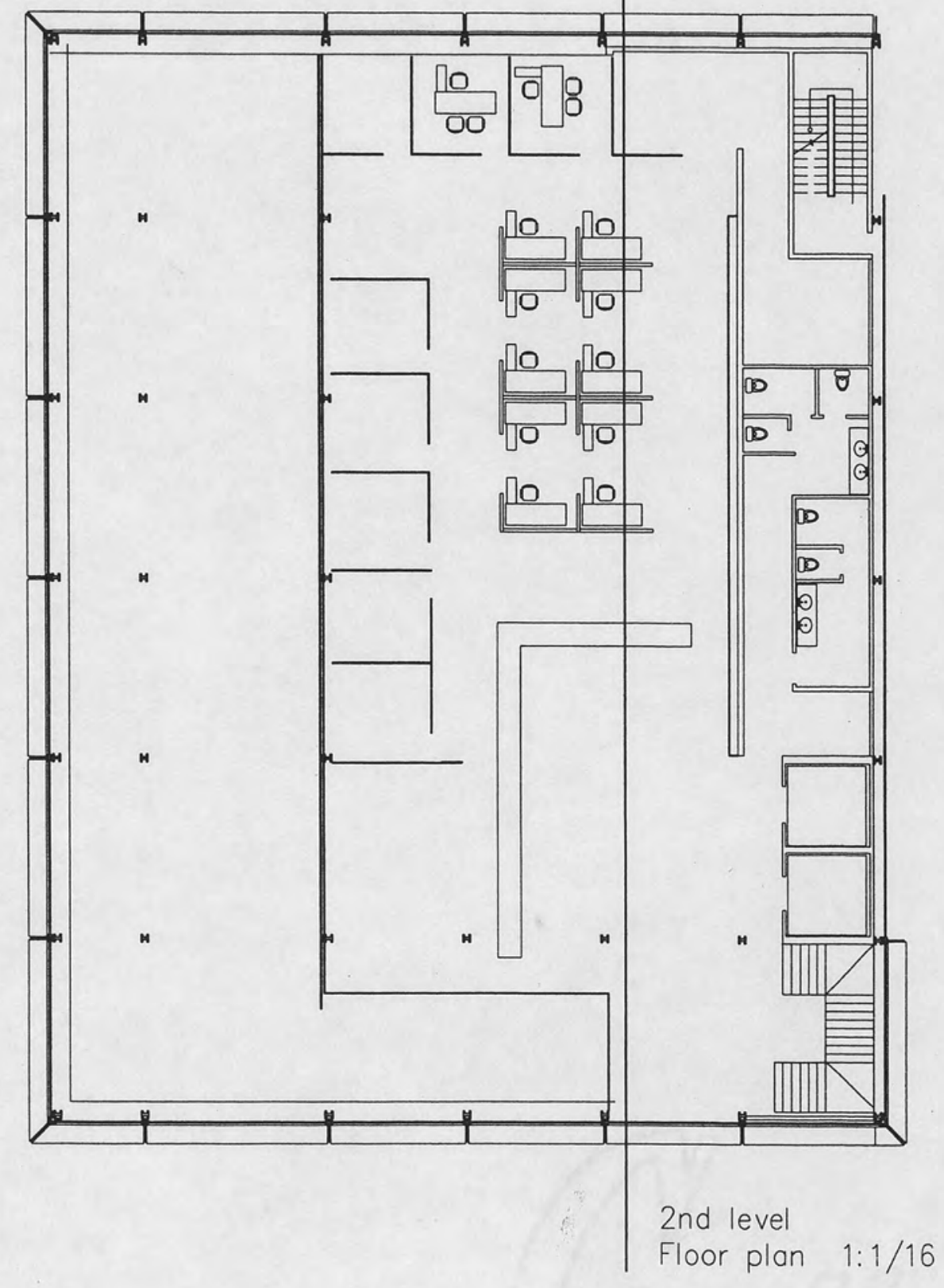



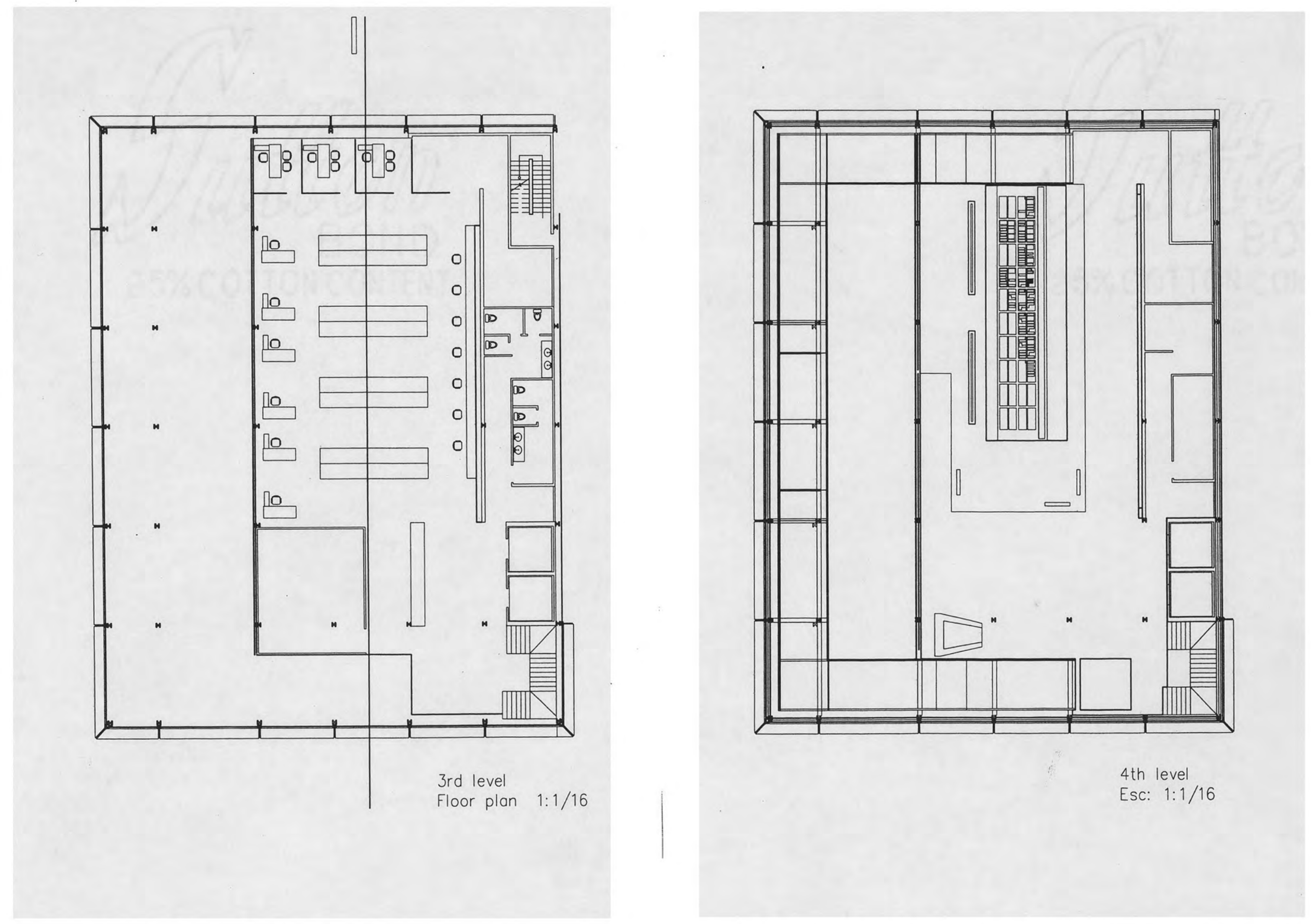

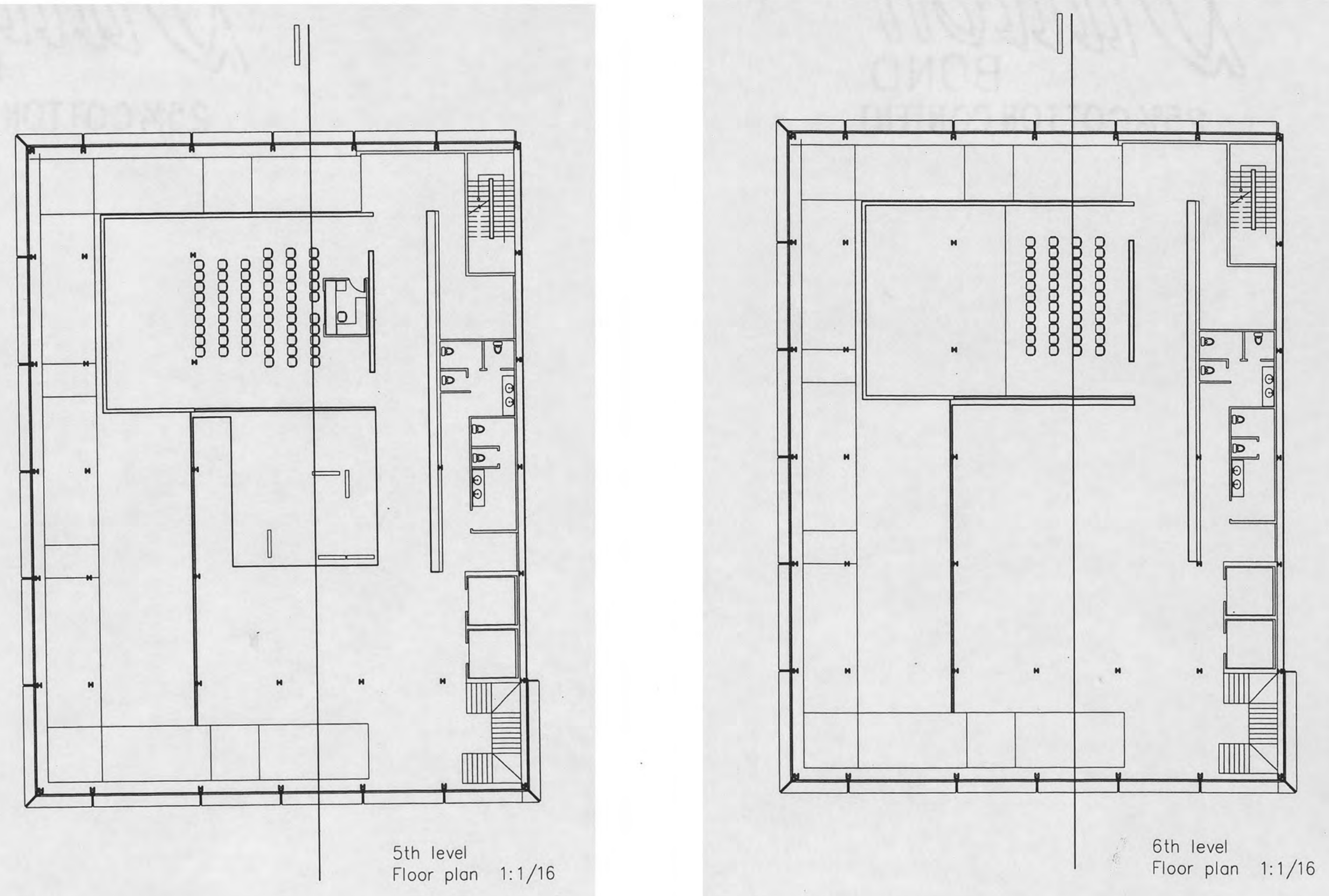

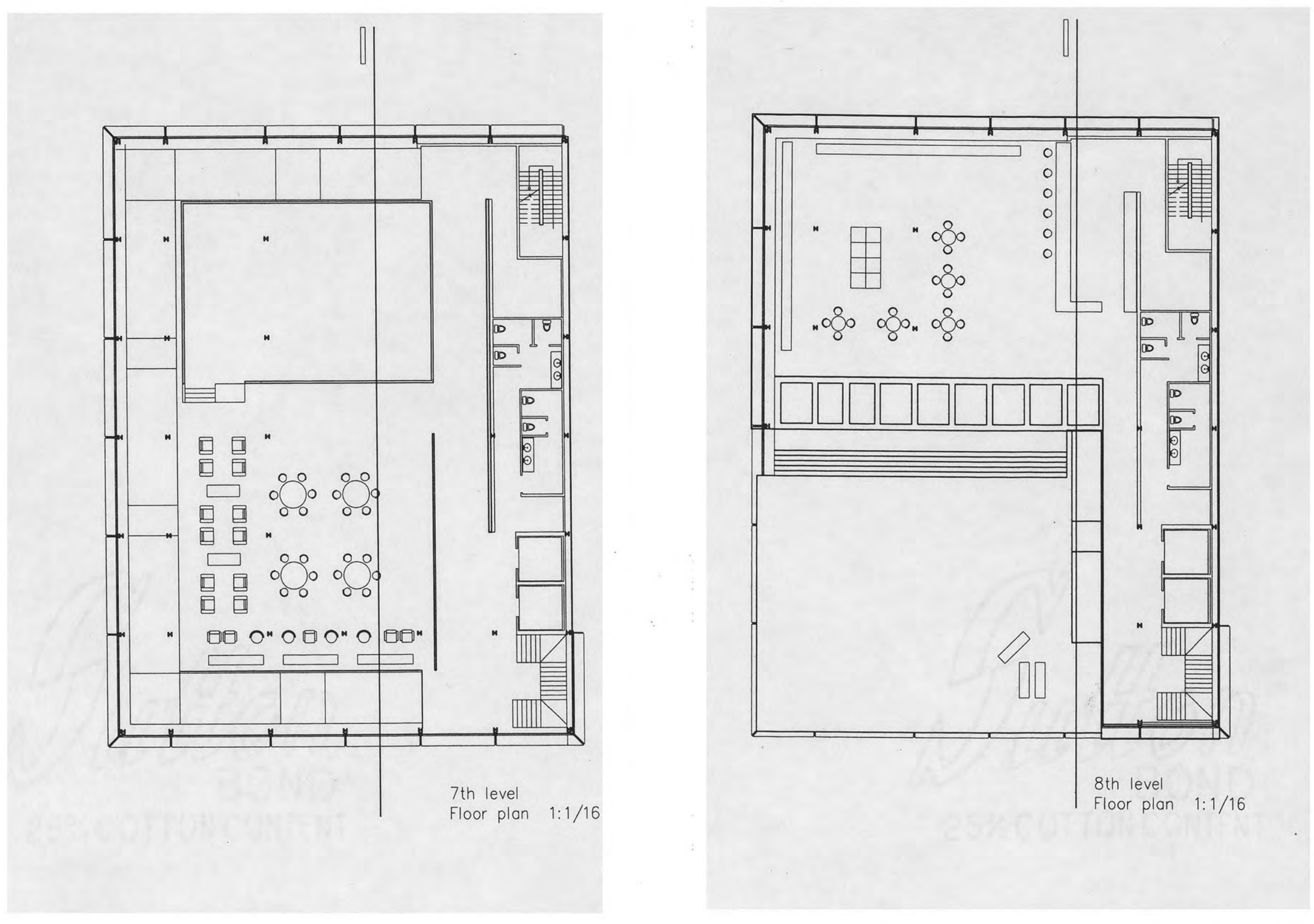


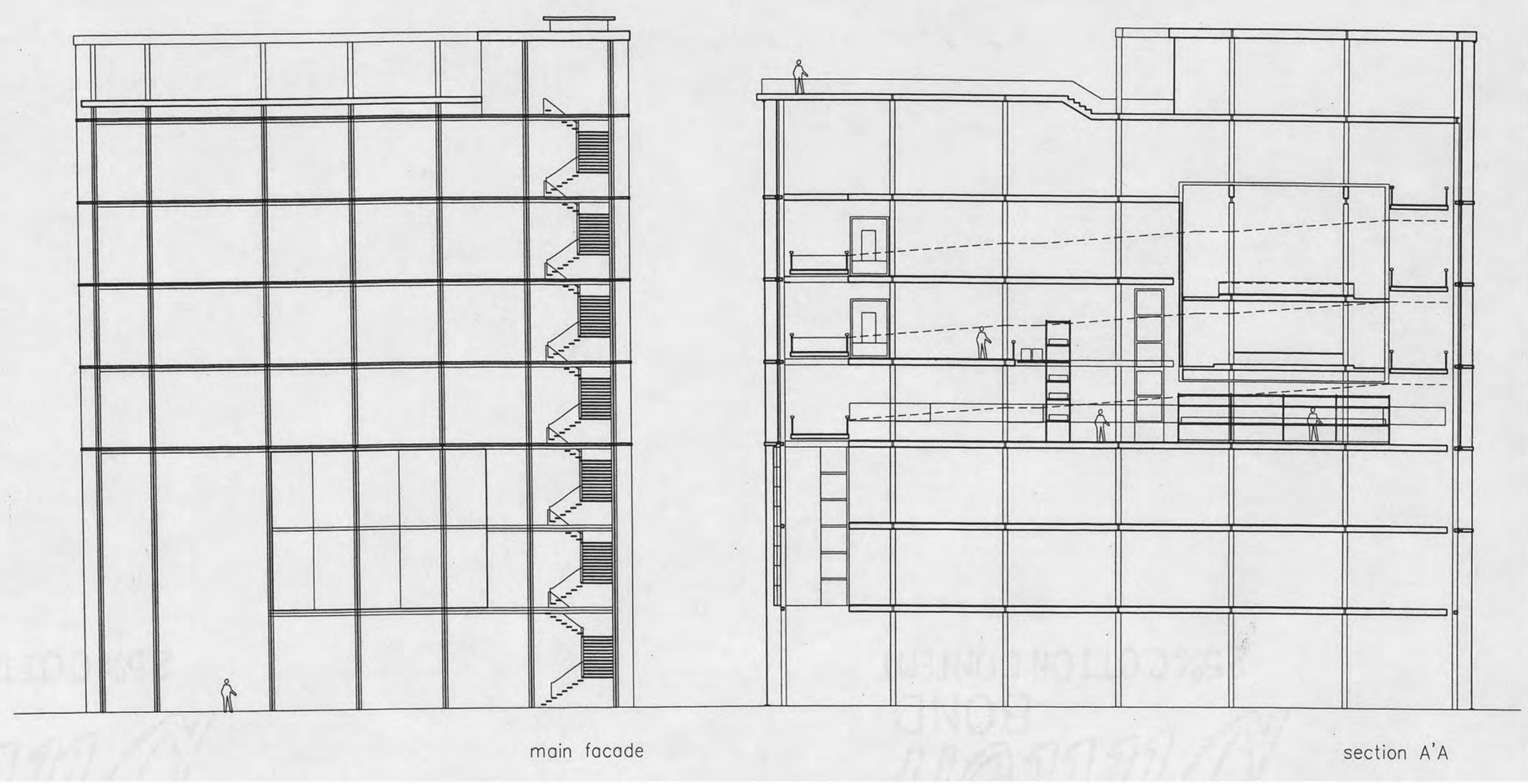




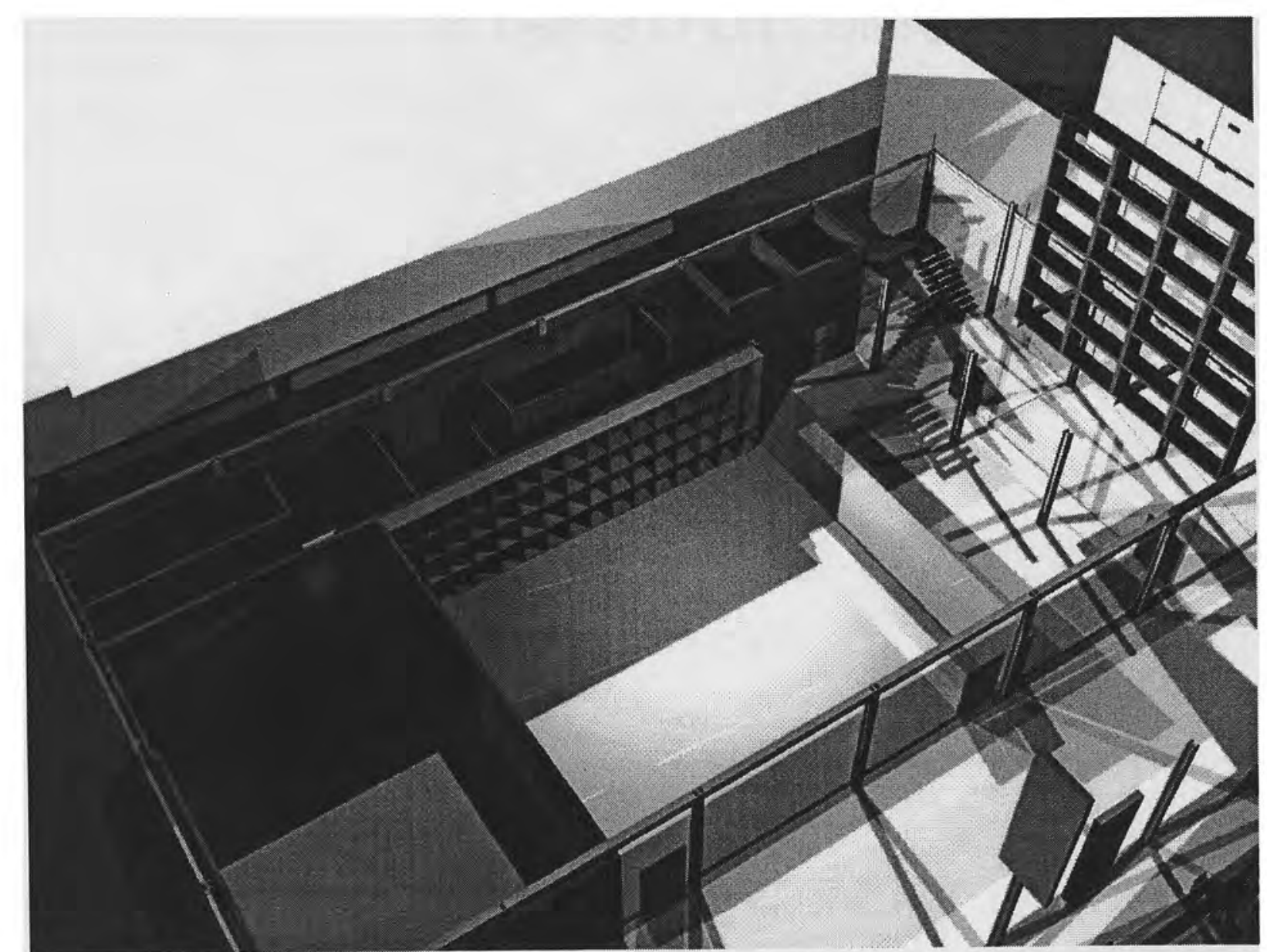

Fig 65

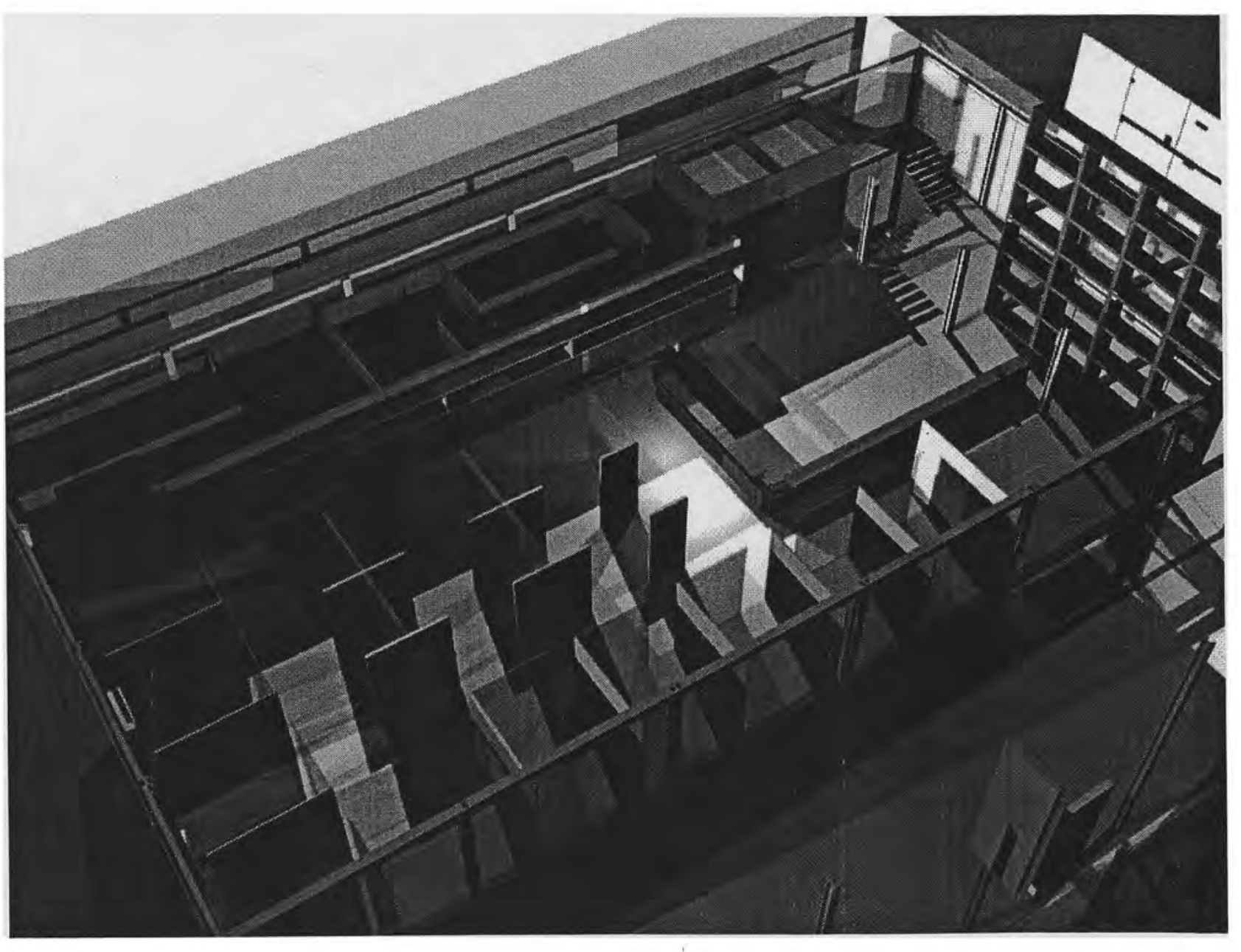

Fig $66 \quad$ SECOND LEVEL 


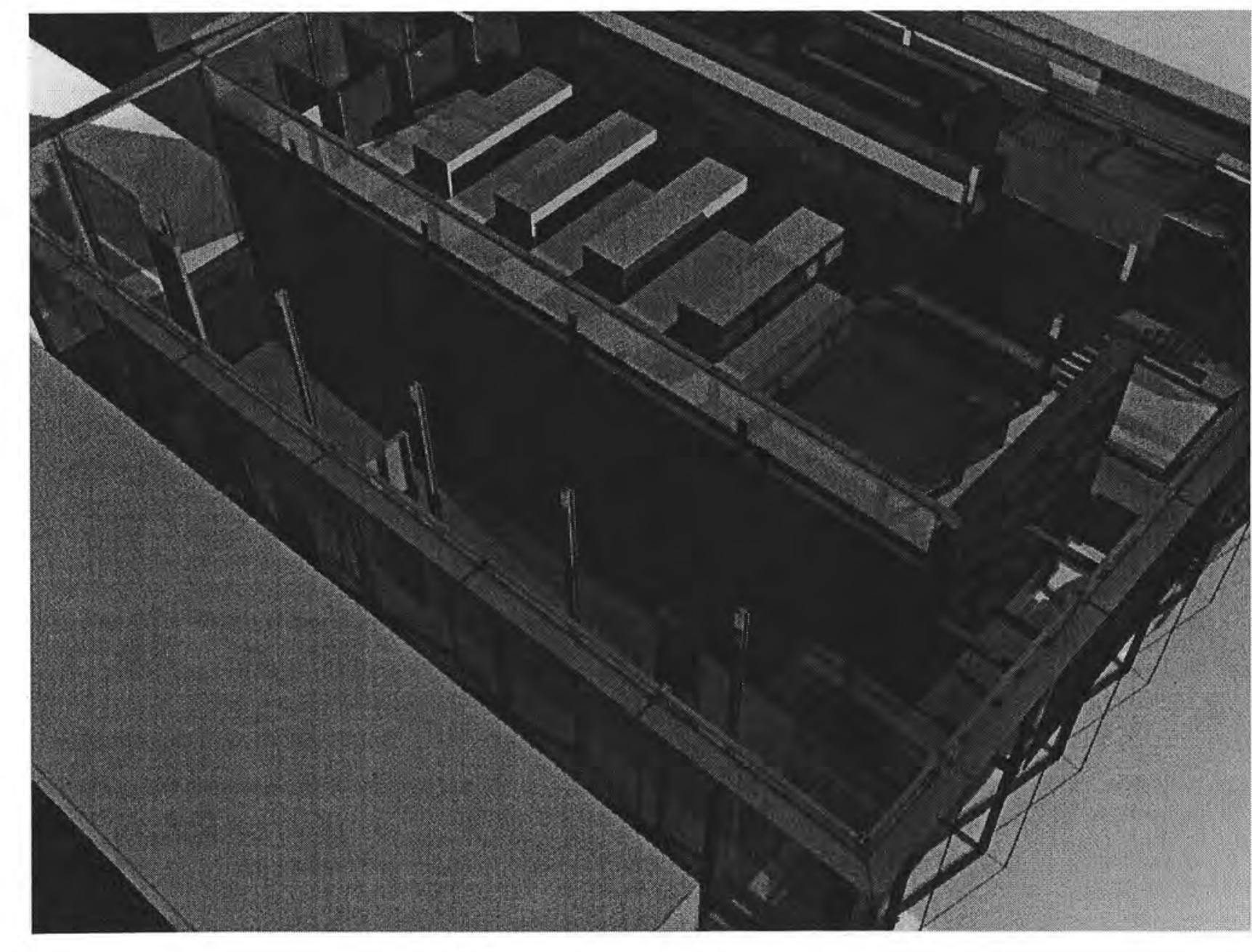

Fig 67

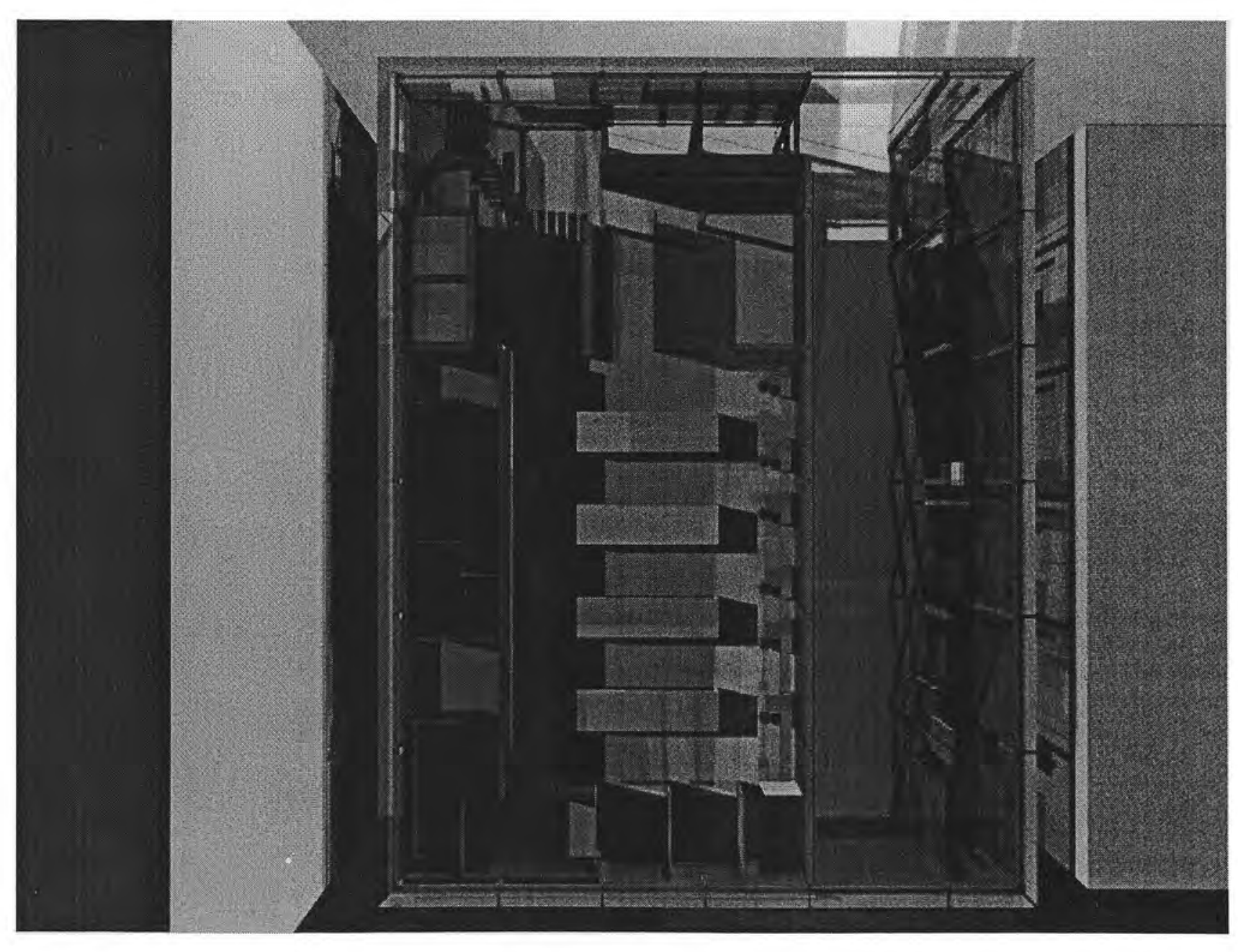

Fig 68 THIRD LEVEL 


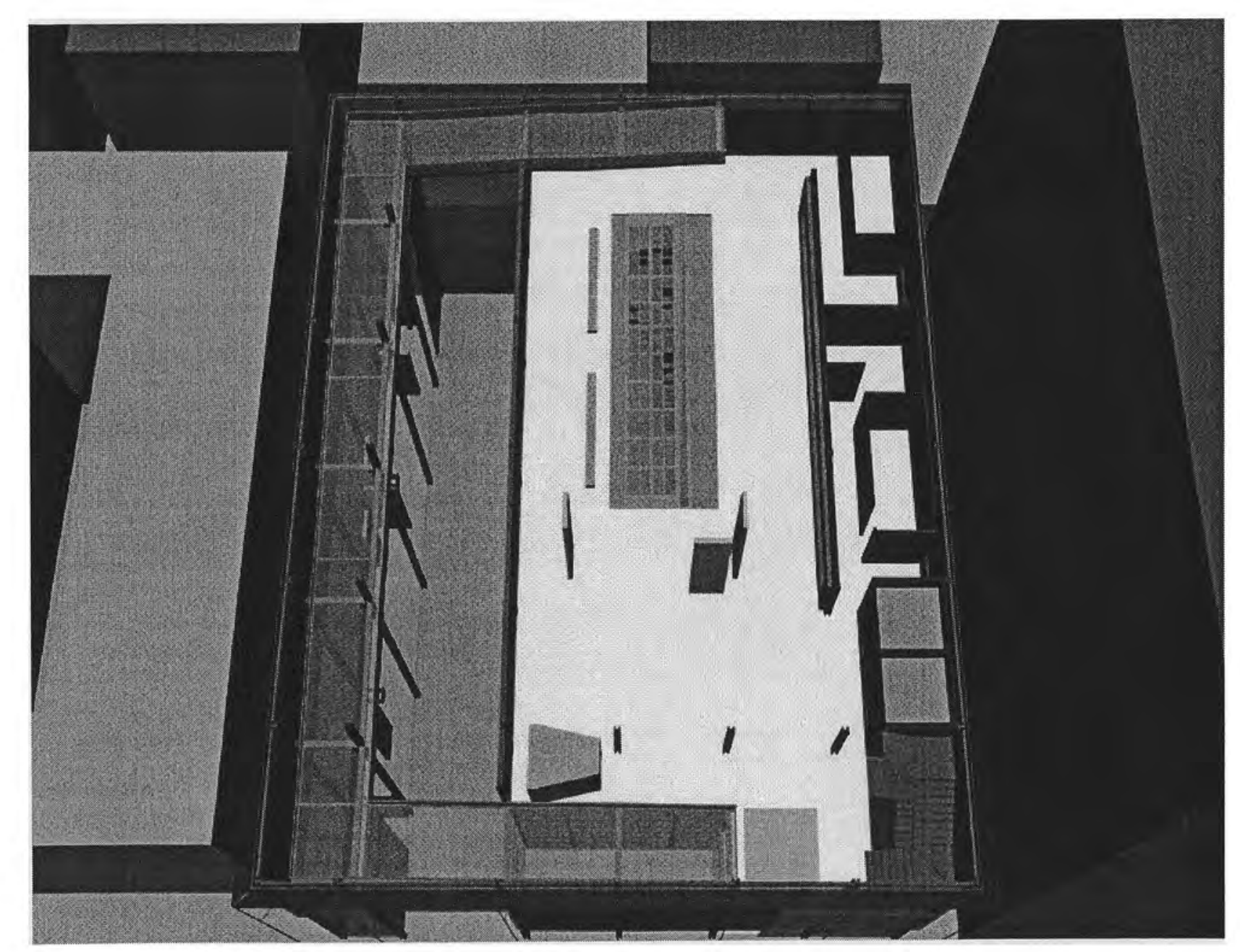

Fig 69

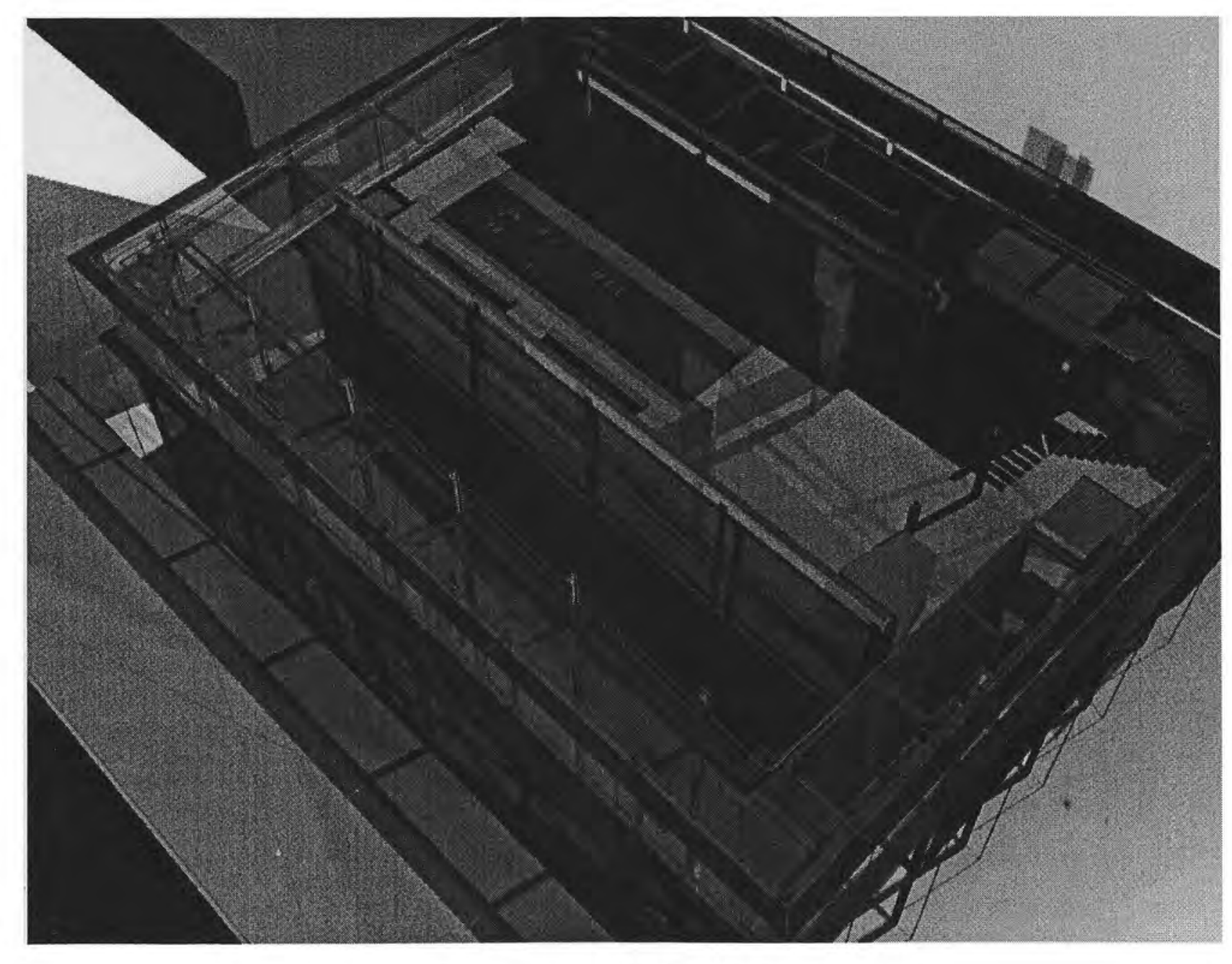

Fig70 FOURTH LEVEL 


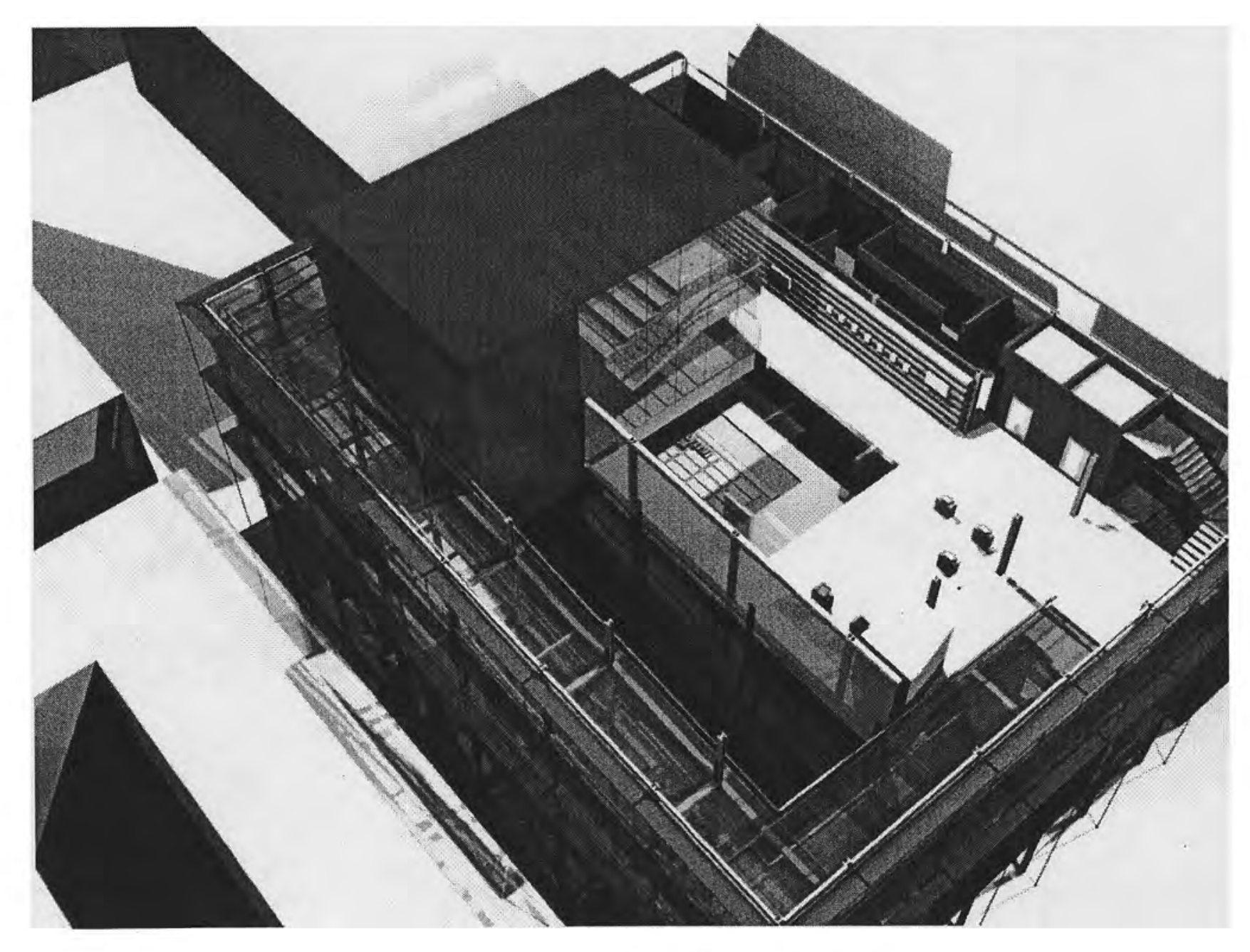

Fig 71 FIFTH LEVEL

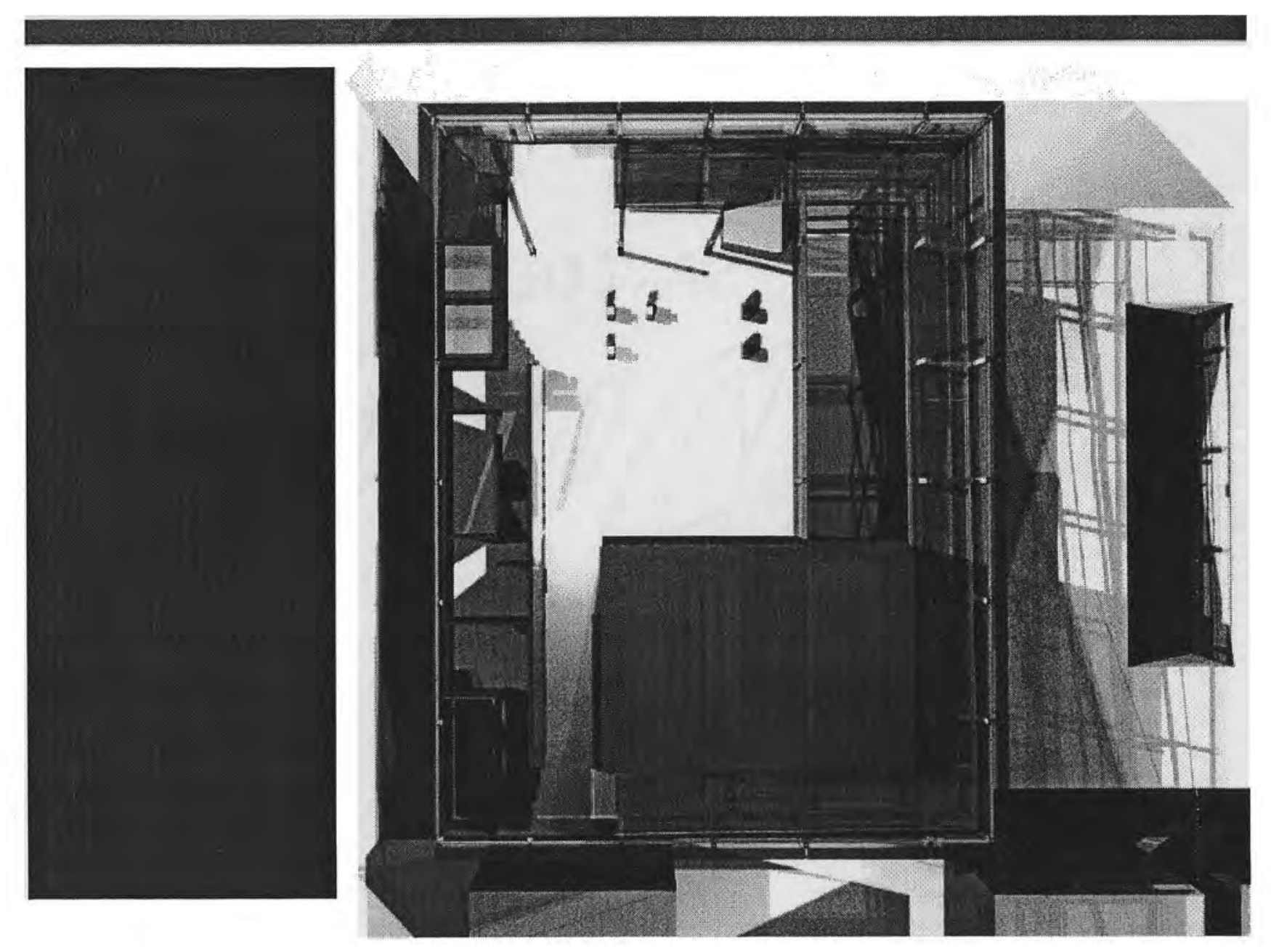

Fig 72 FIFTH LEVEL 


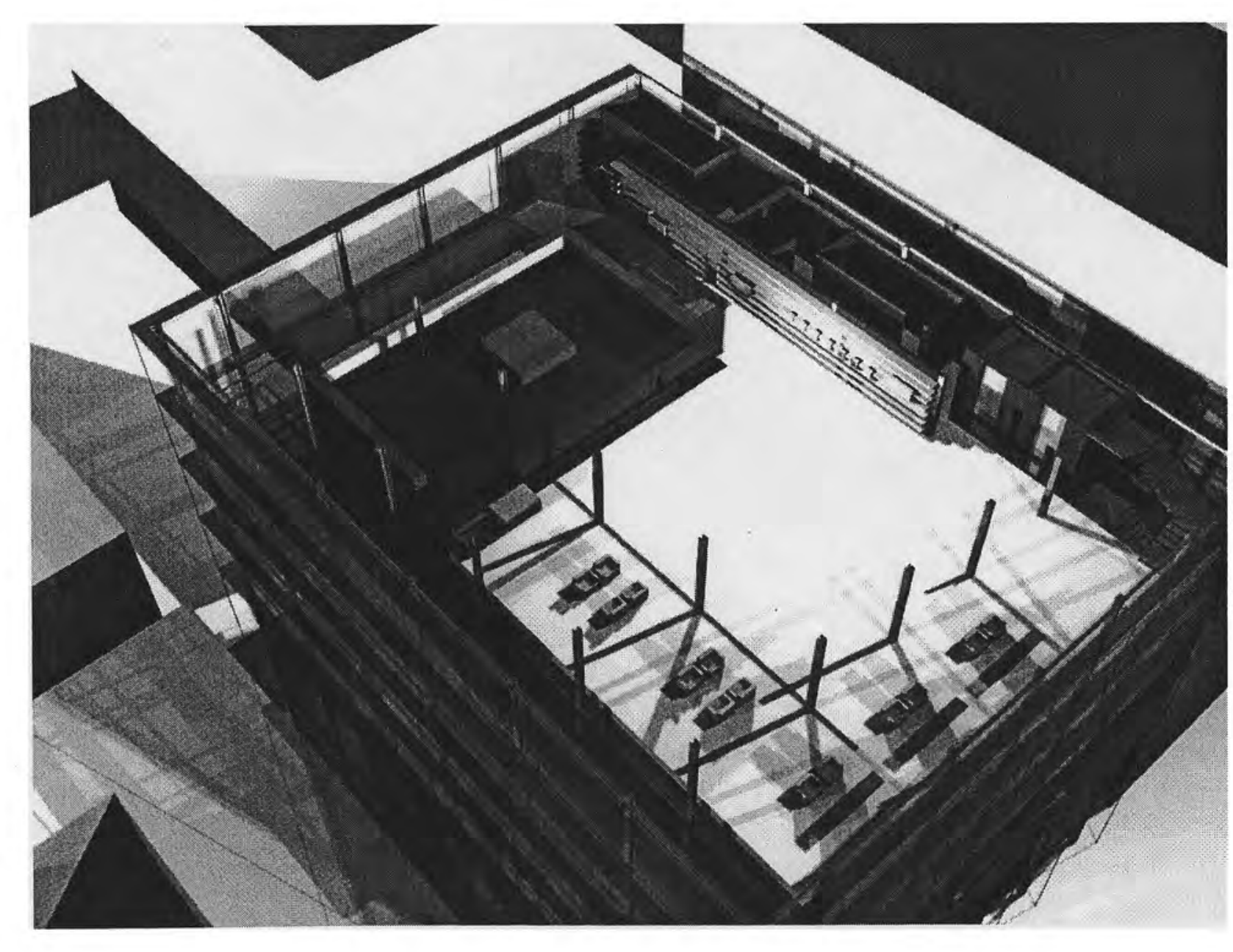

Fig 73 SIXTH LEVEL

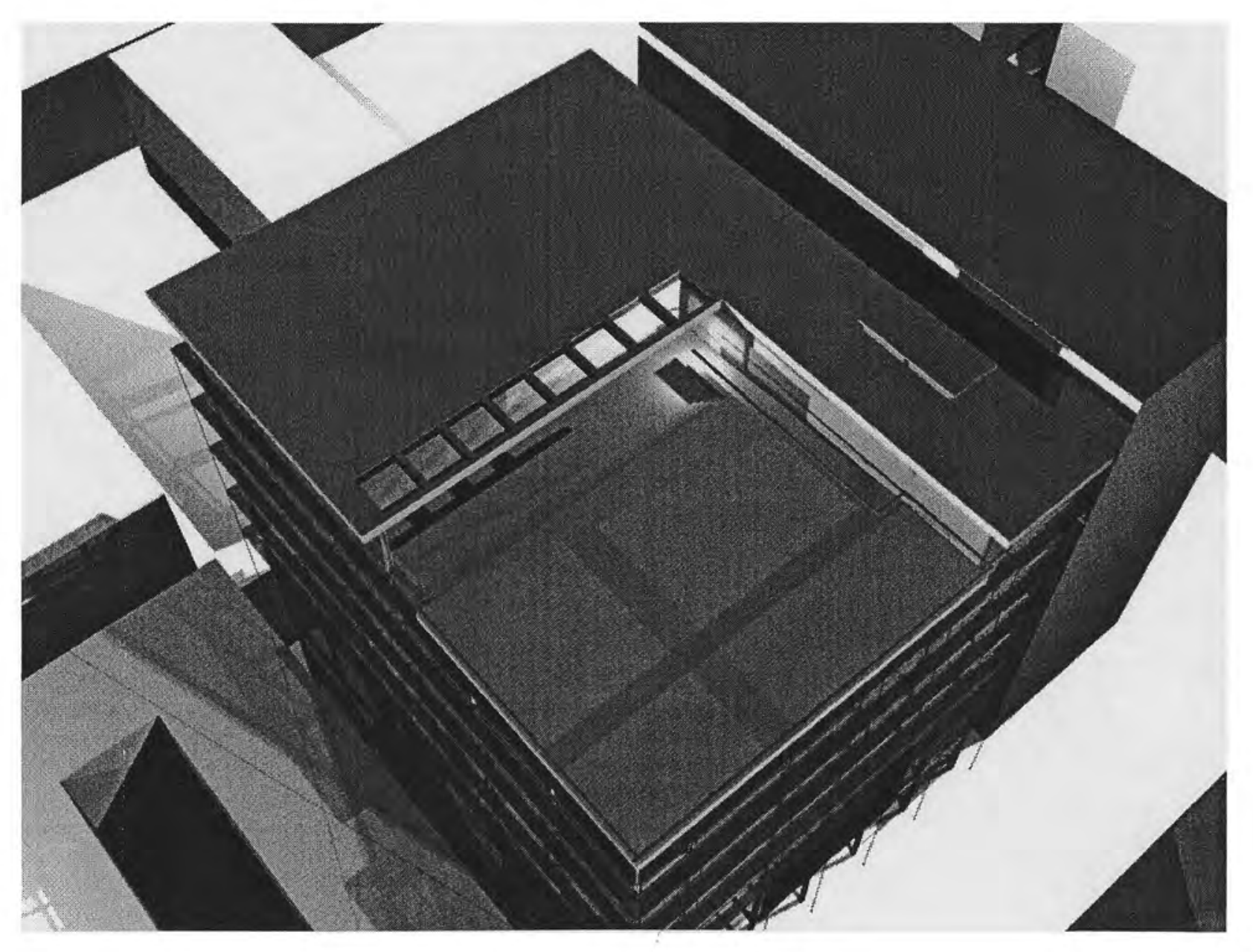

Fig 74 ElGHTH LEVEL 

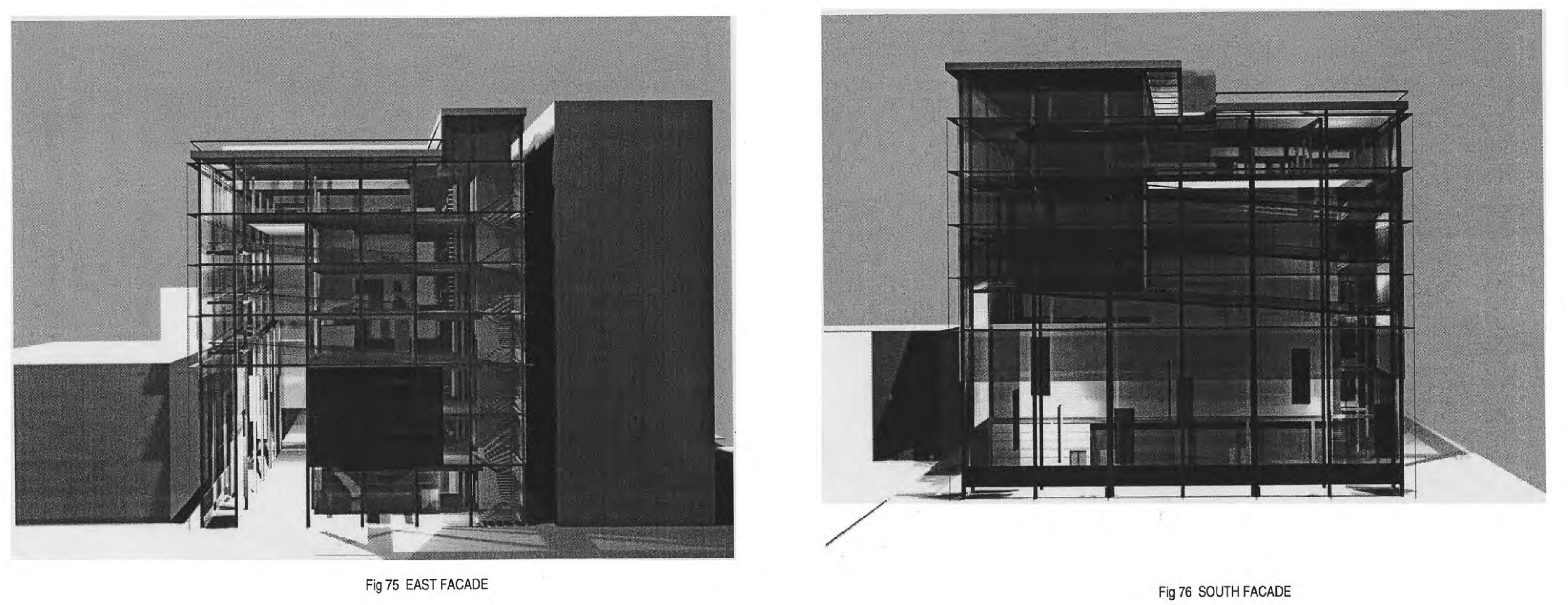


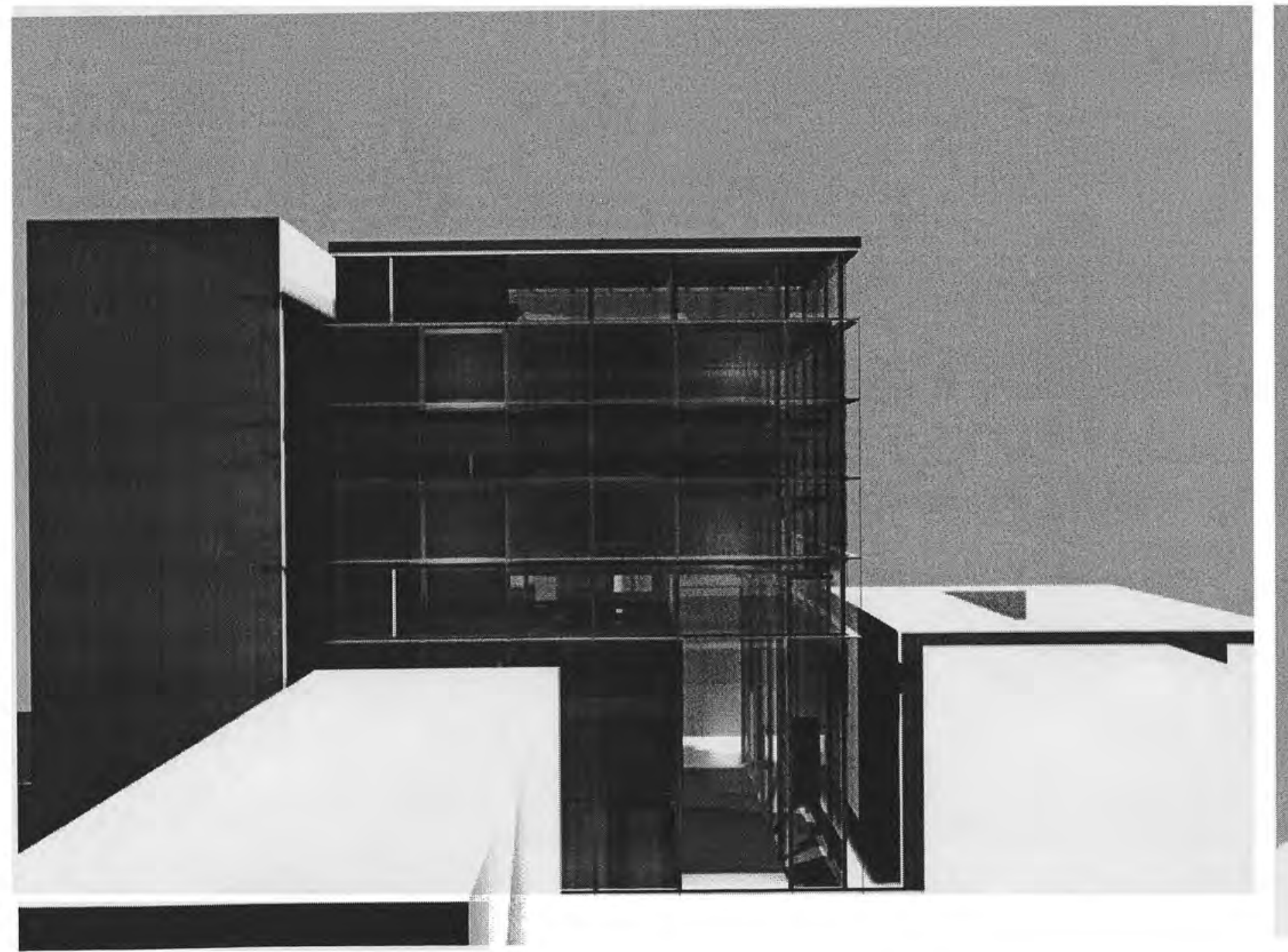

Fig 77 WEST FACADE

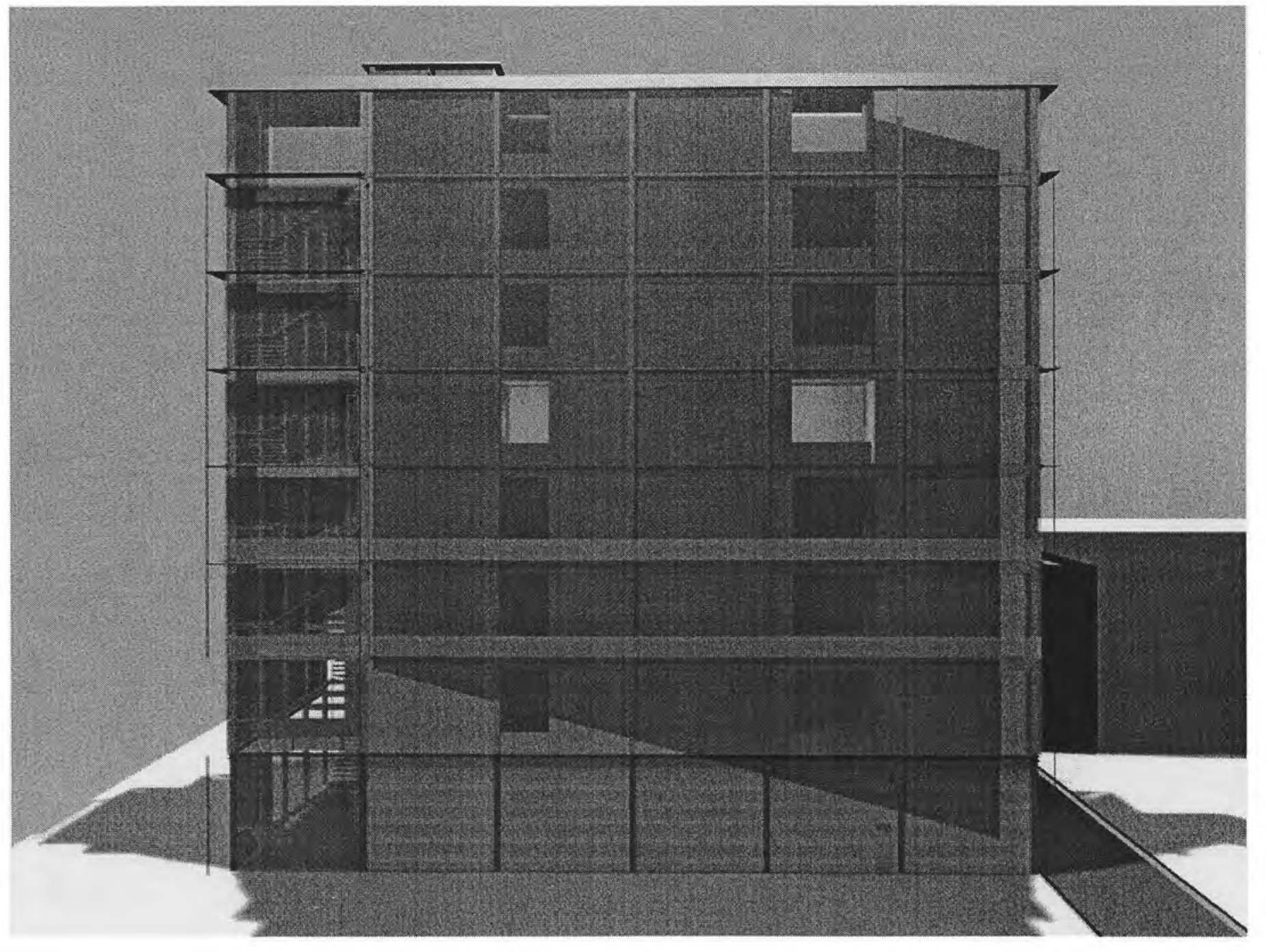

Fig 78 NORTH FACADE 


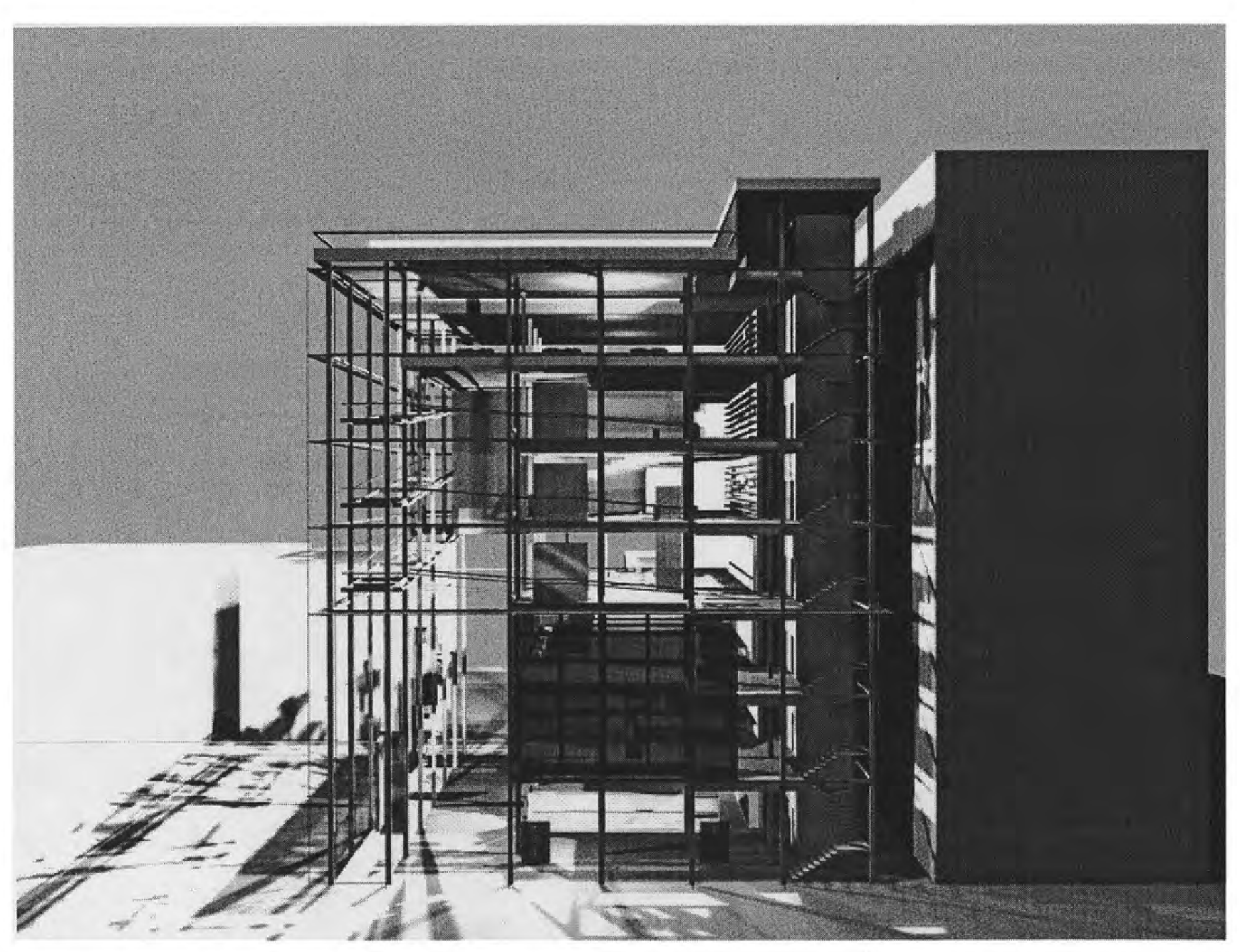

Fig 79 SECTION

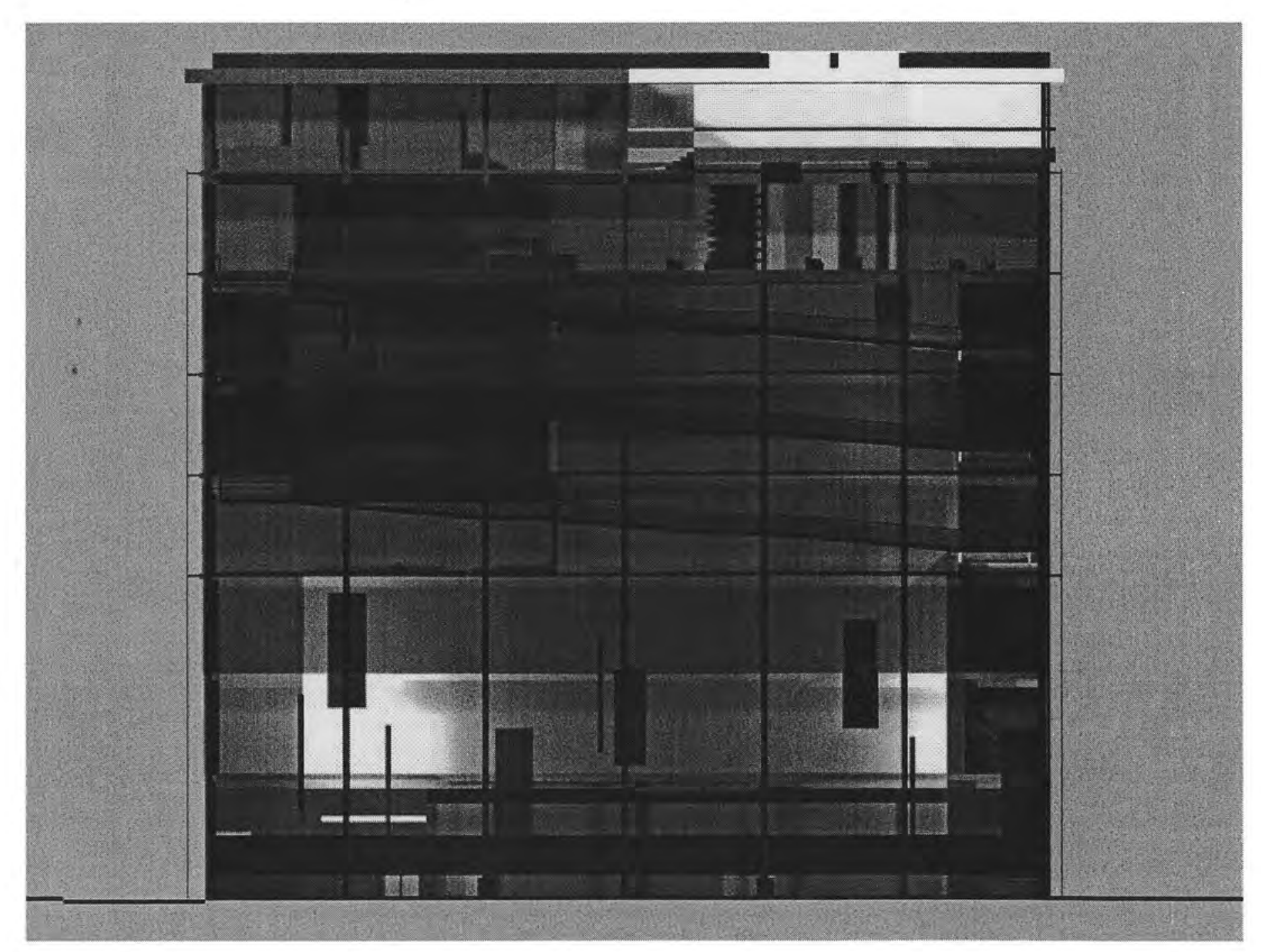

Fig 80 SECTION 


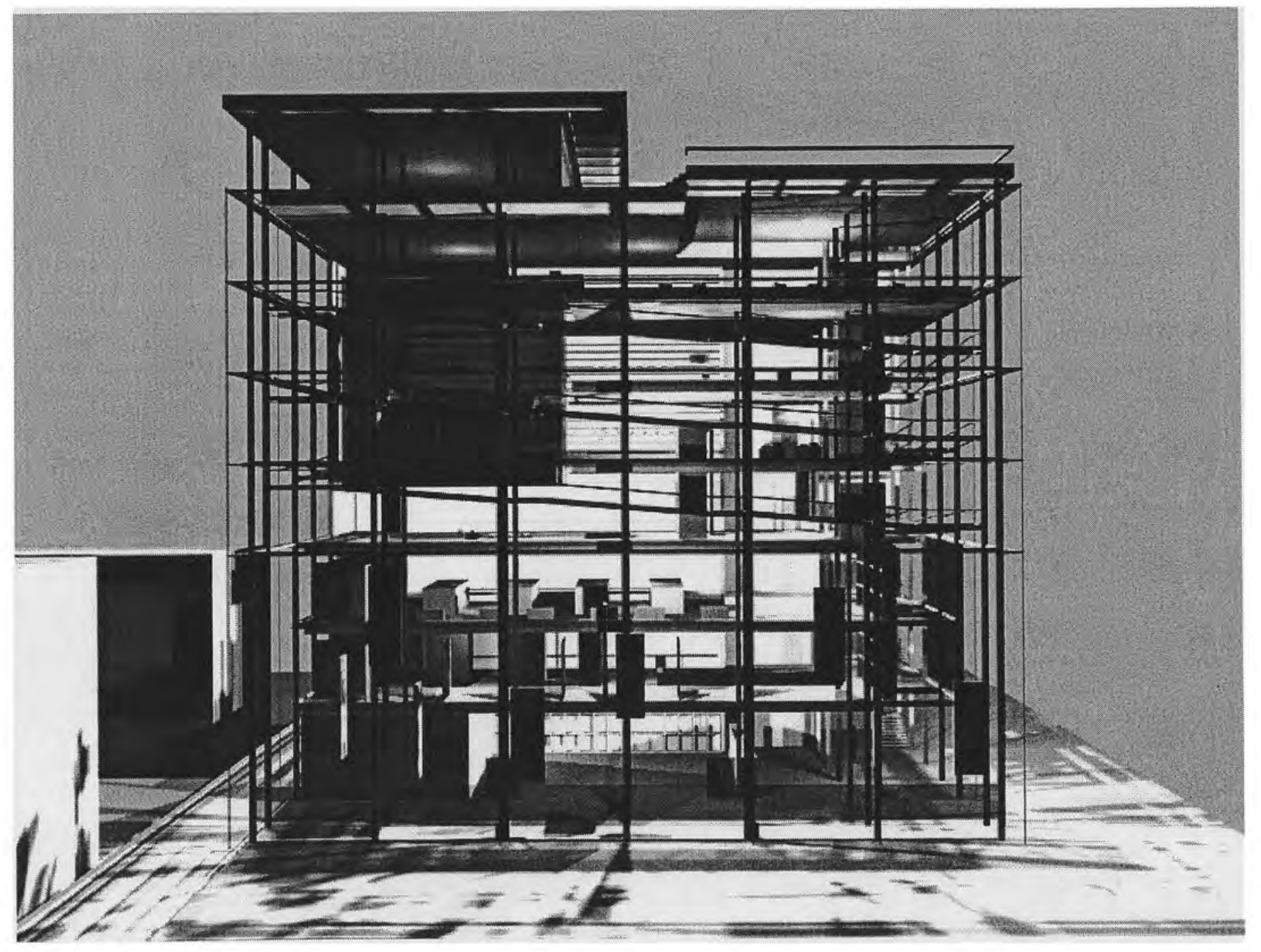

Fig 81 SECTION

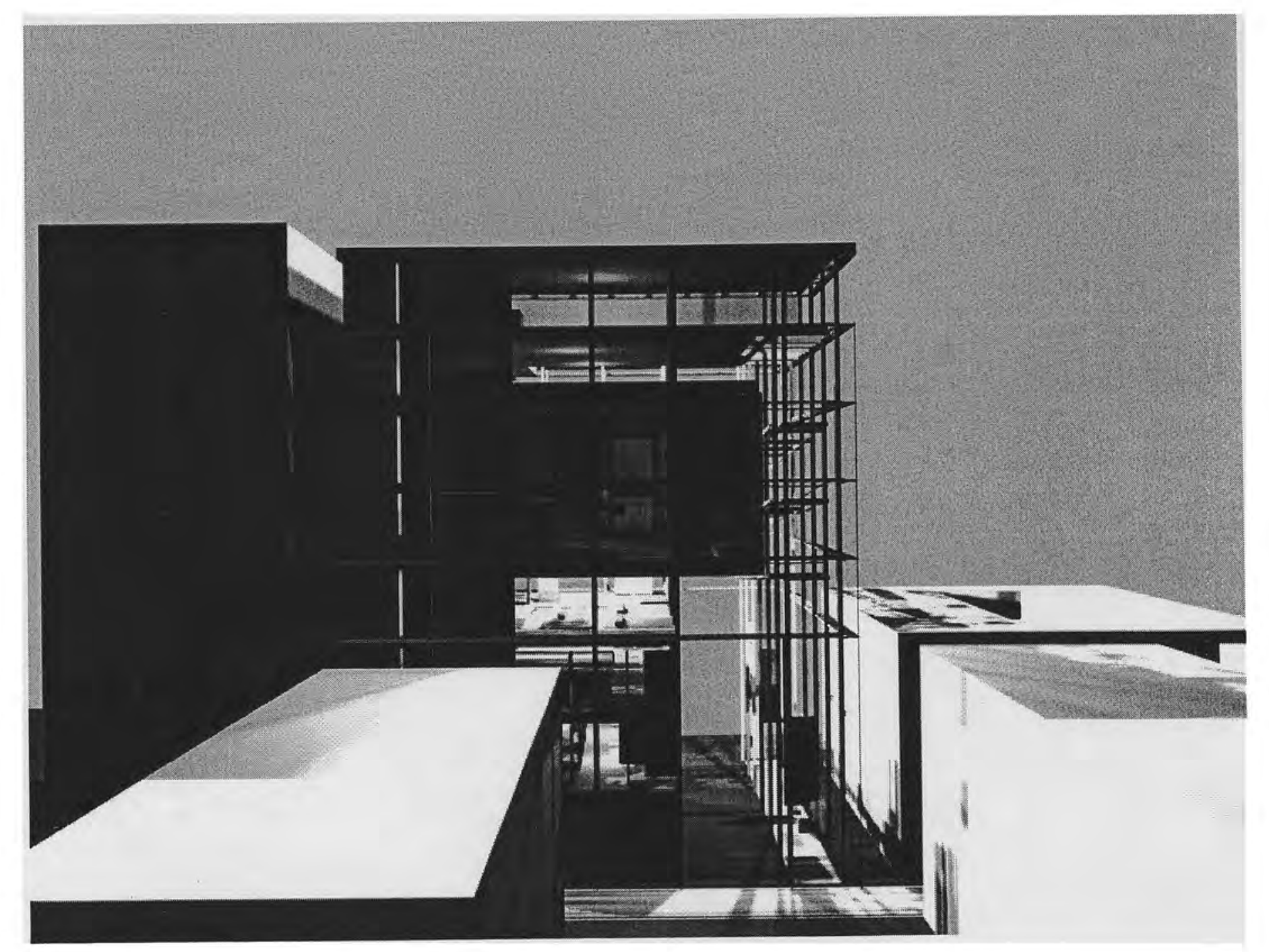

Fig 82 SECTION 


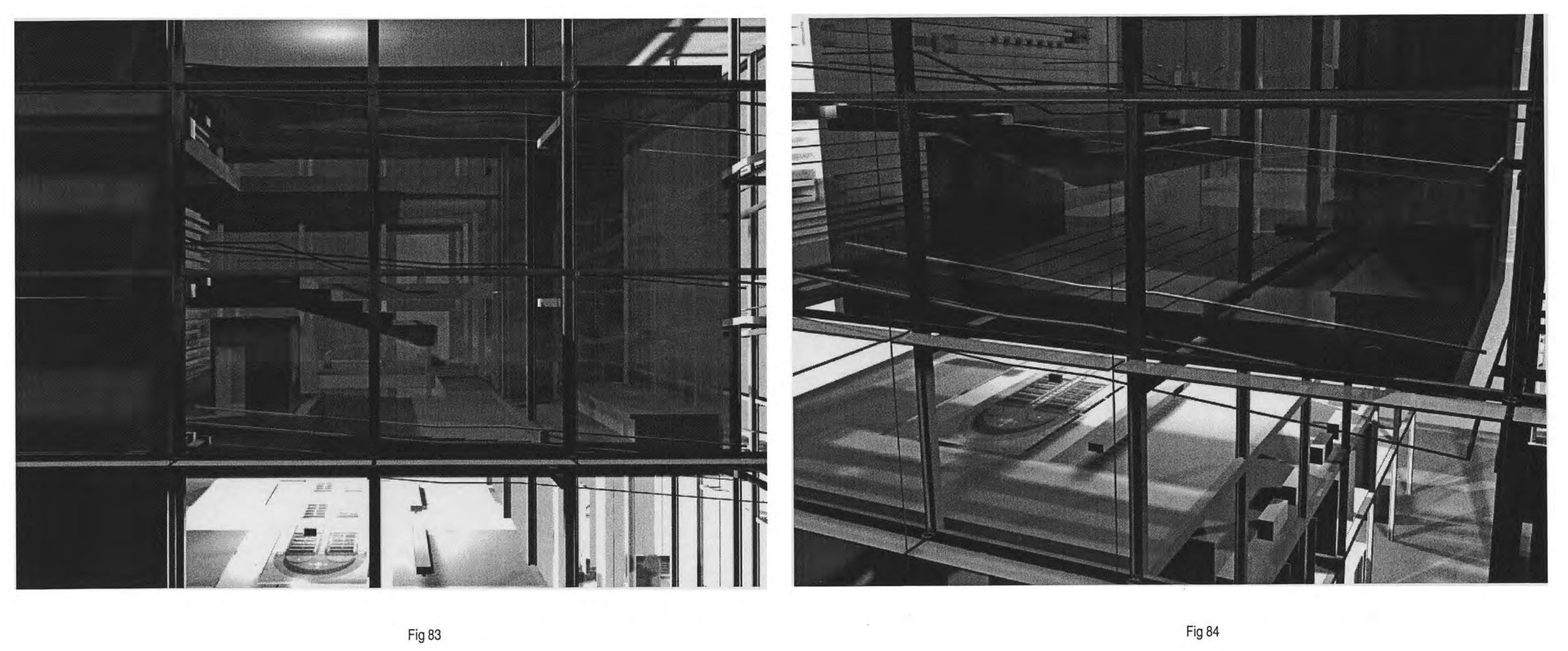




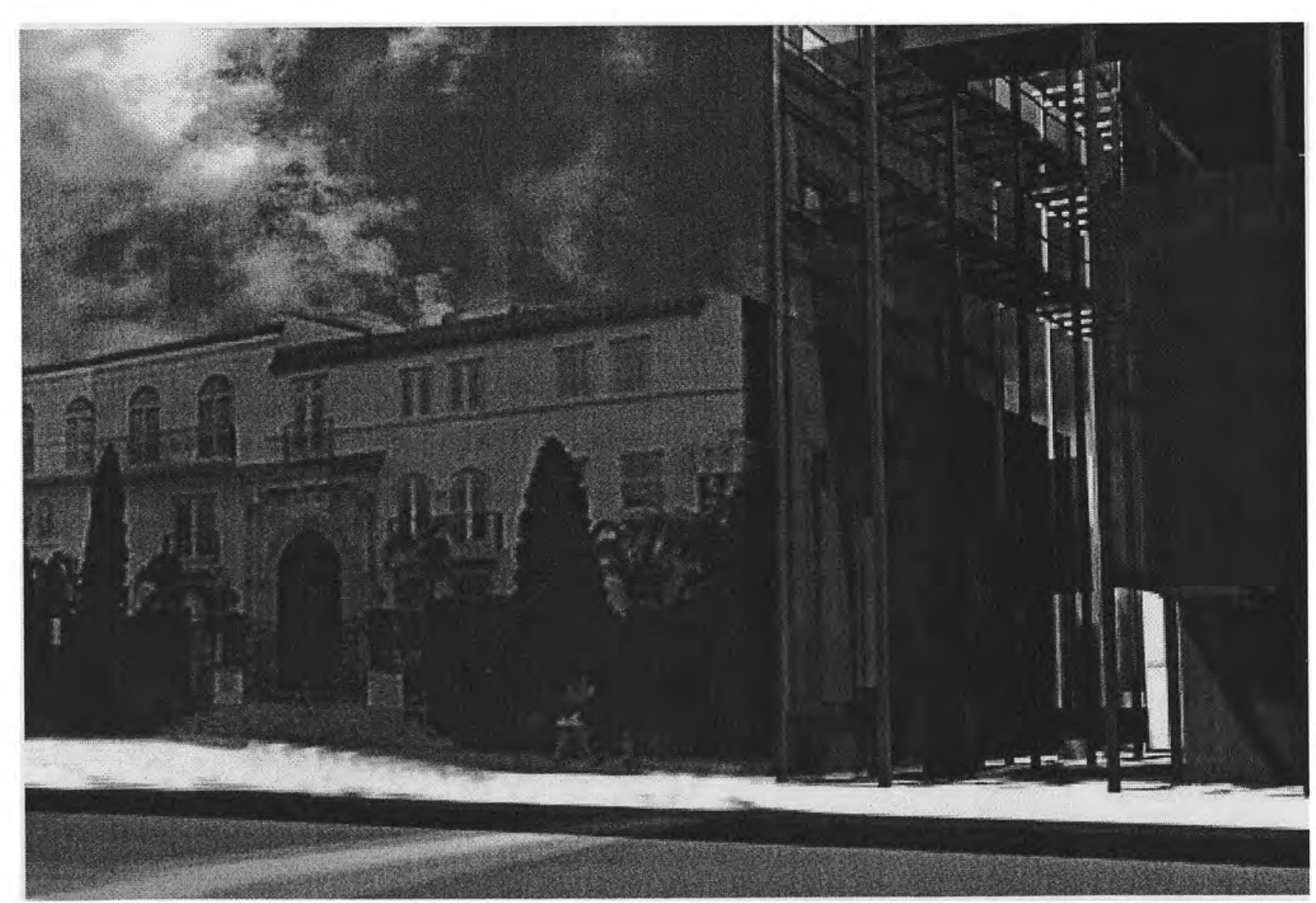

Fig 85

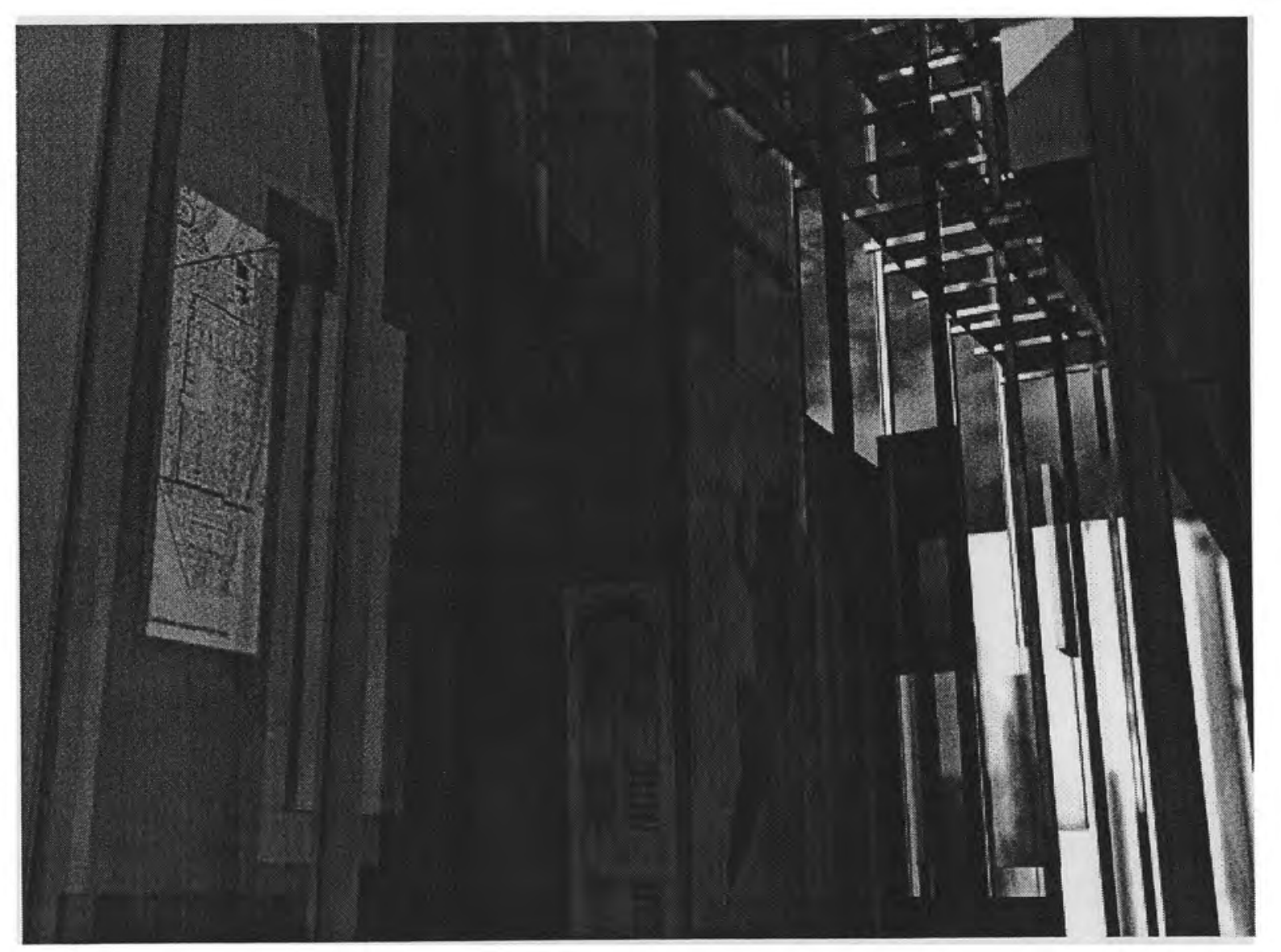

Fig 86 

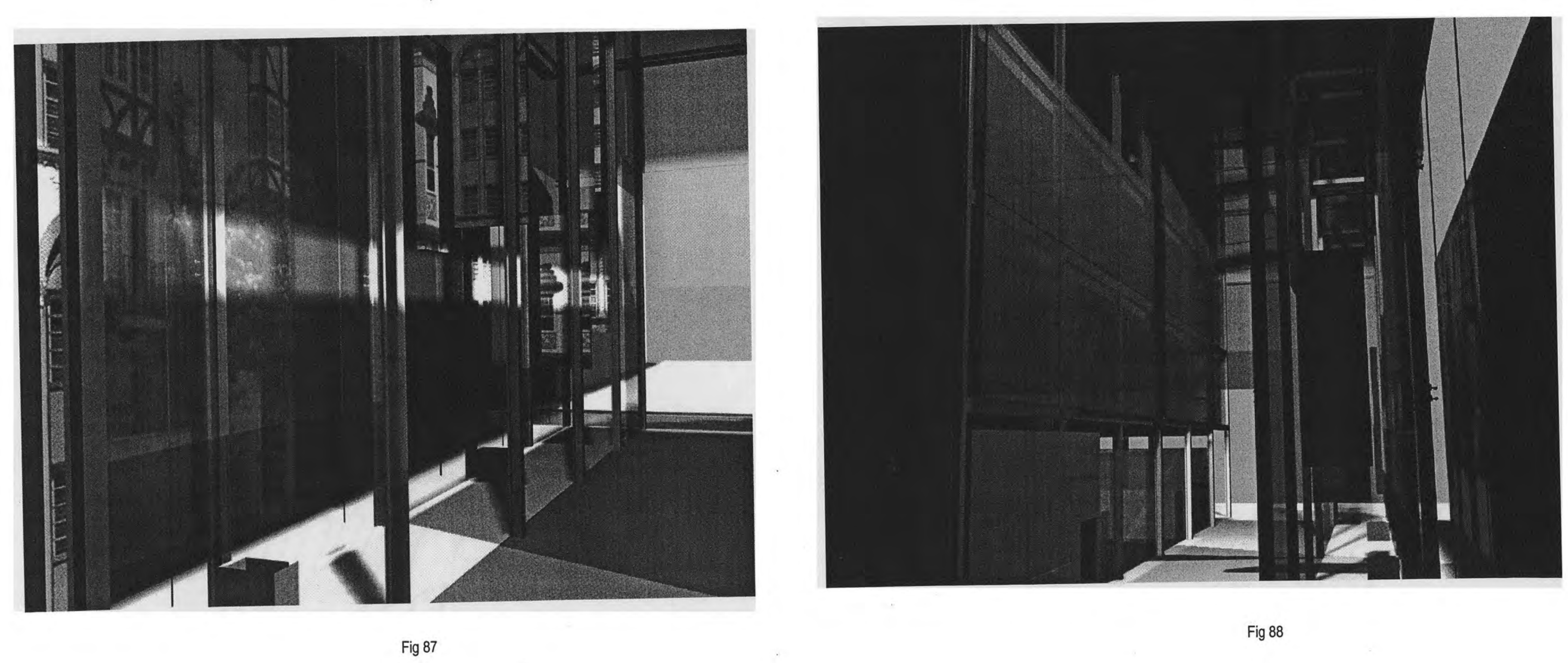


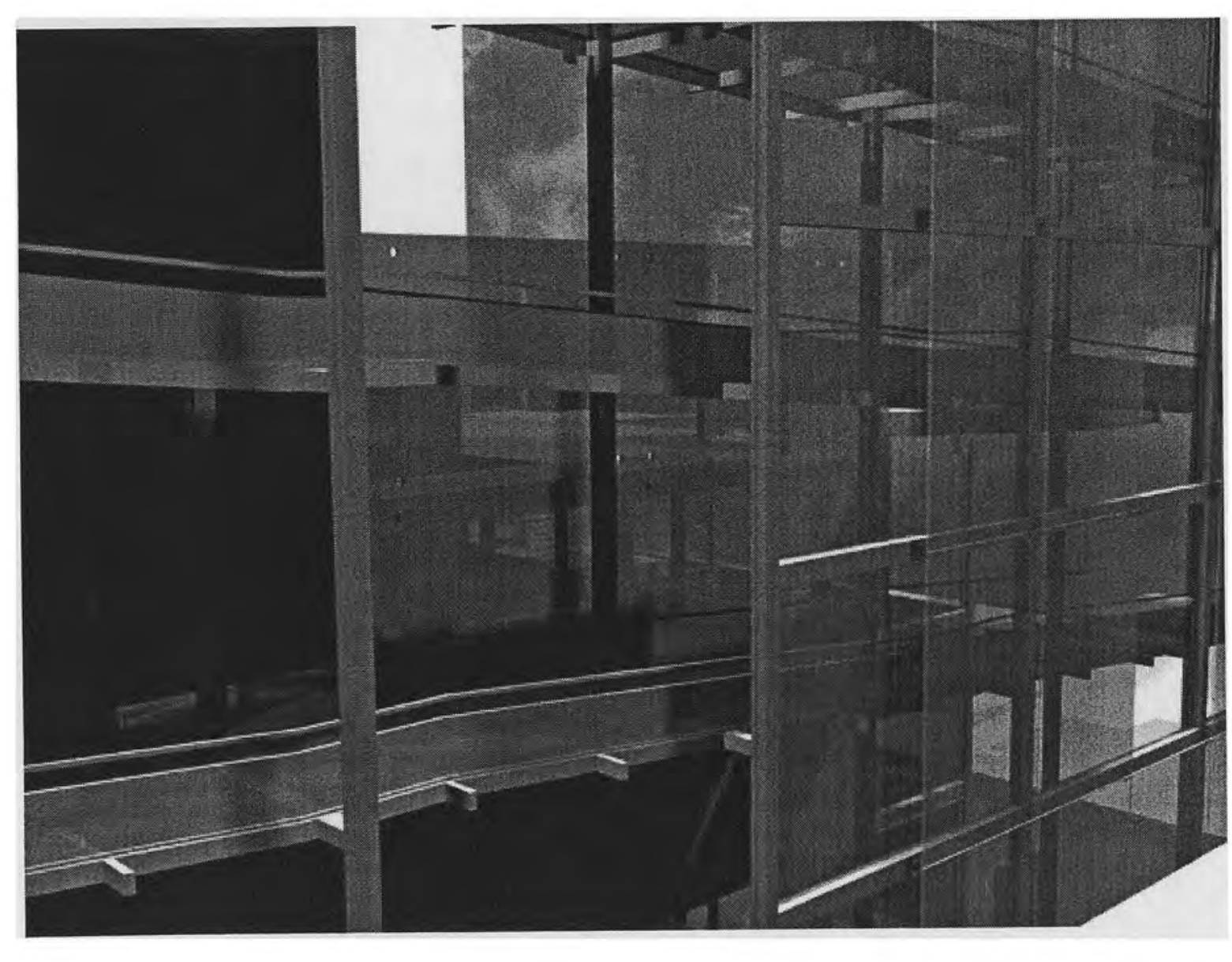

Fig 89

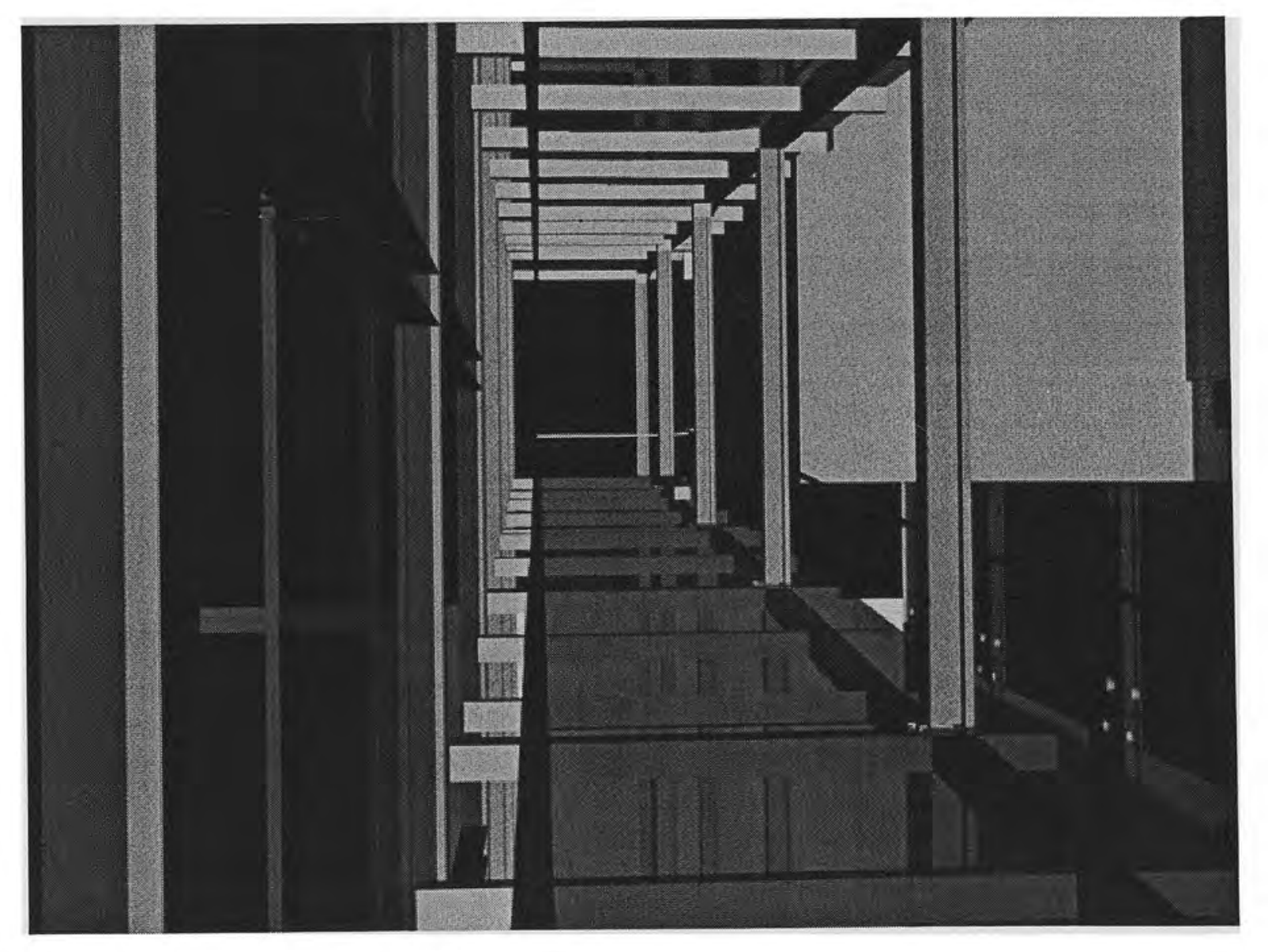

Fig 90 

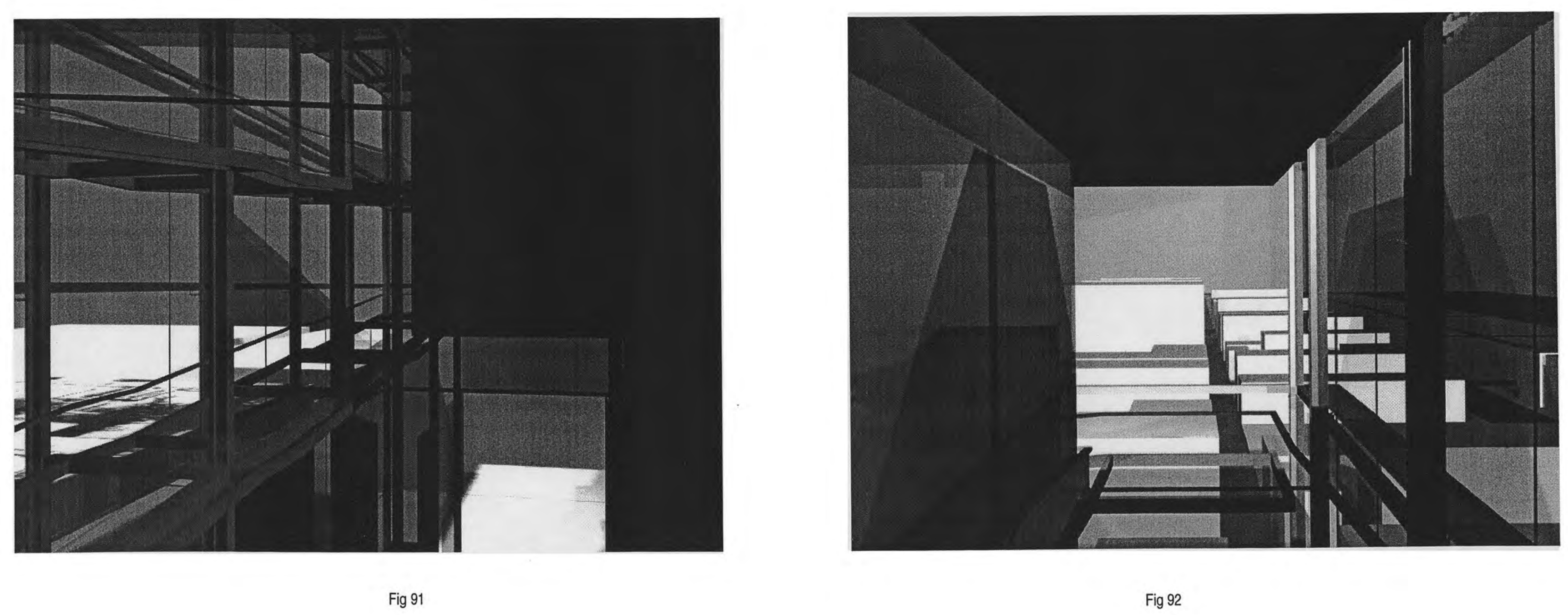


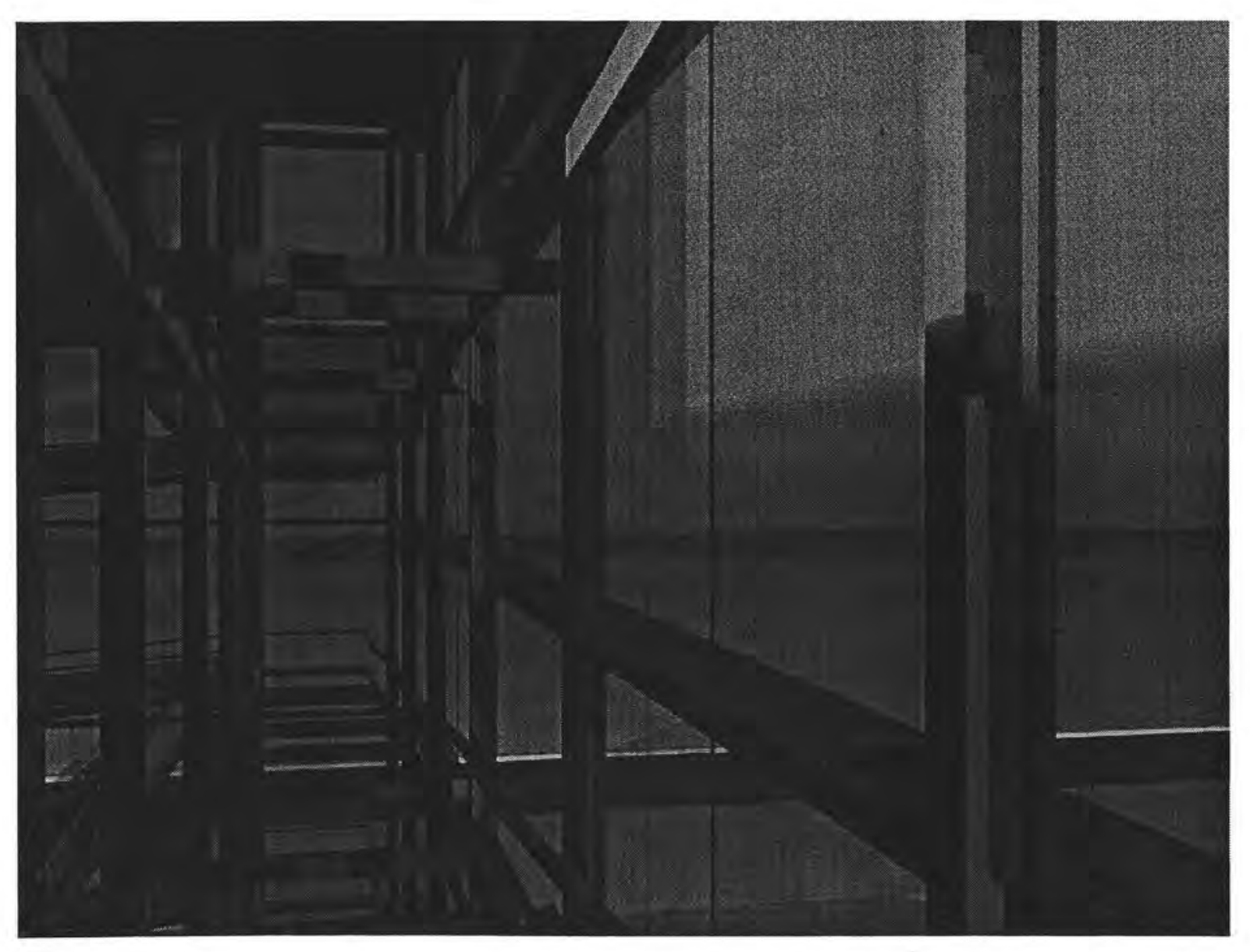

Fig 93

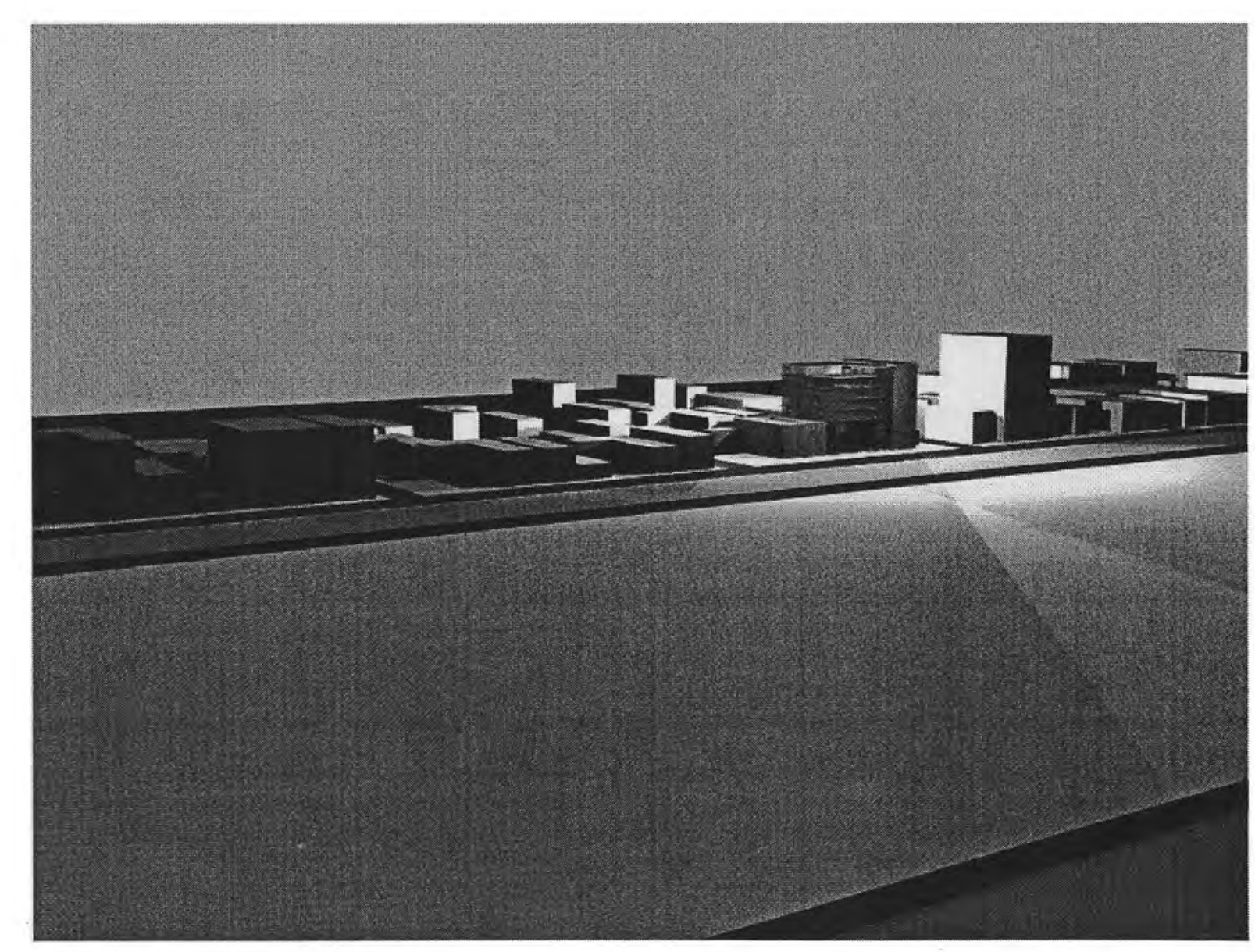

Fig 94 


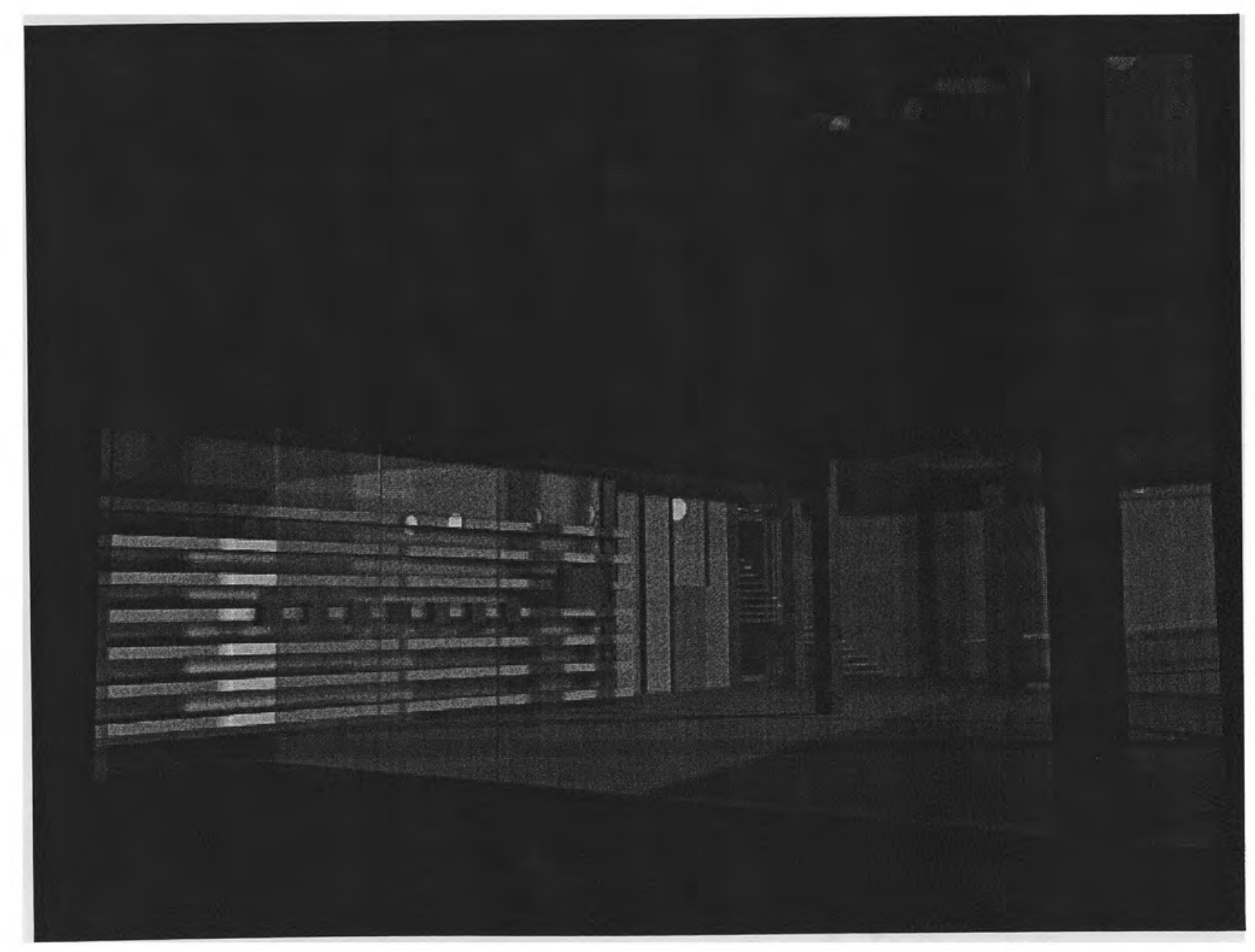

Fig 95

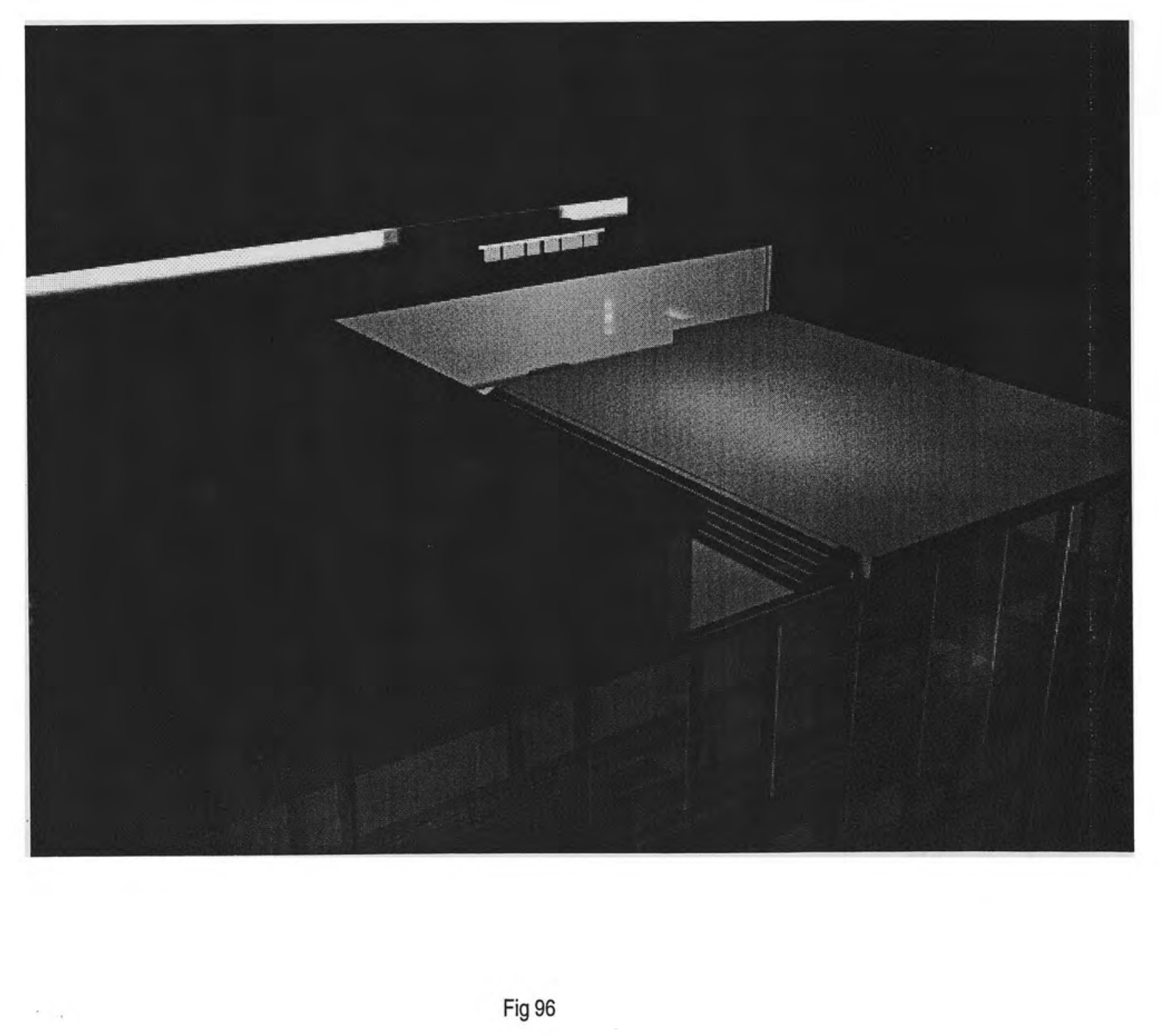




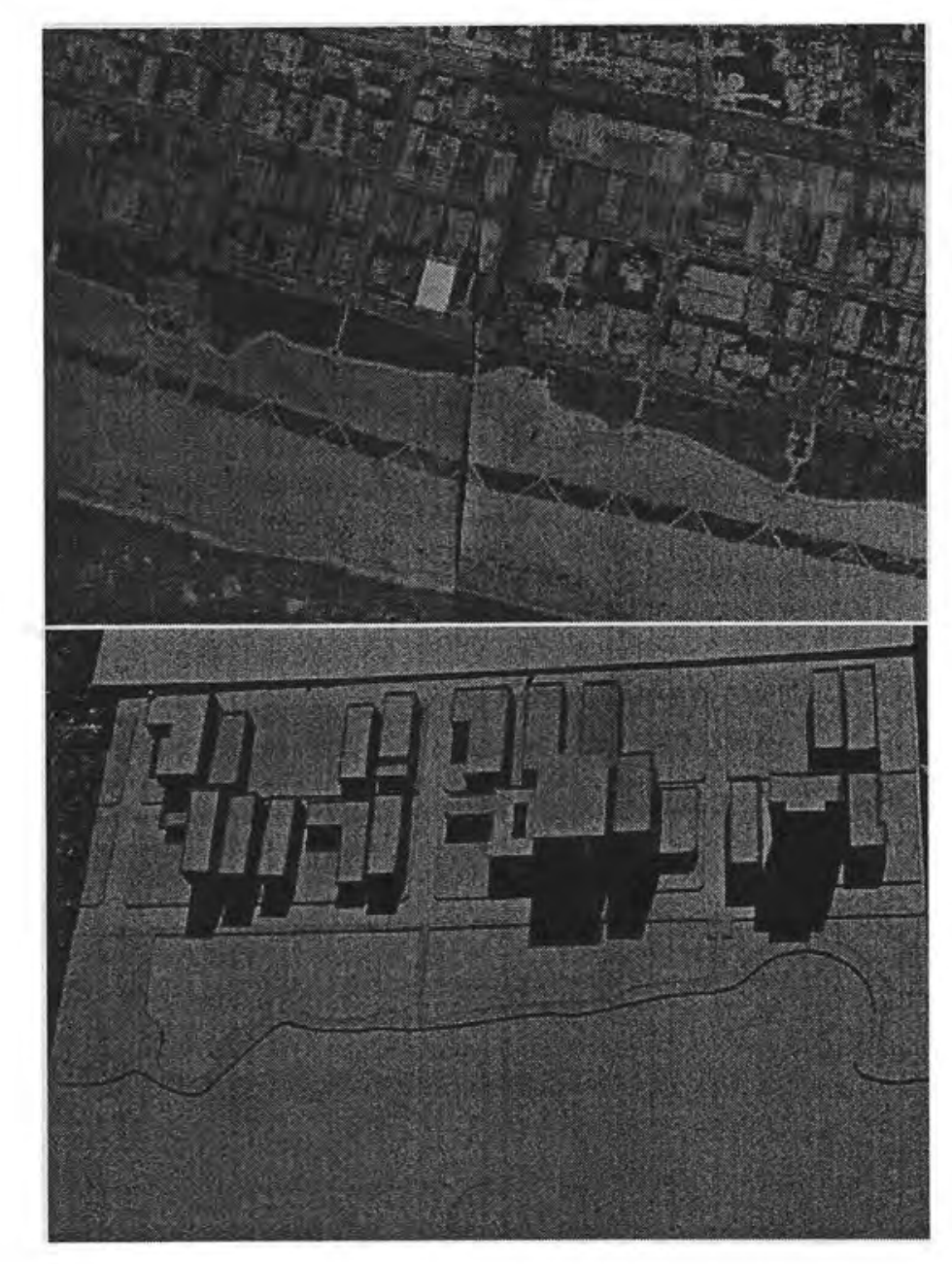

Fig 97

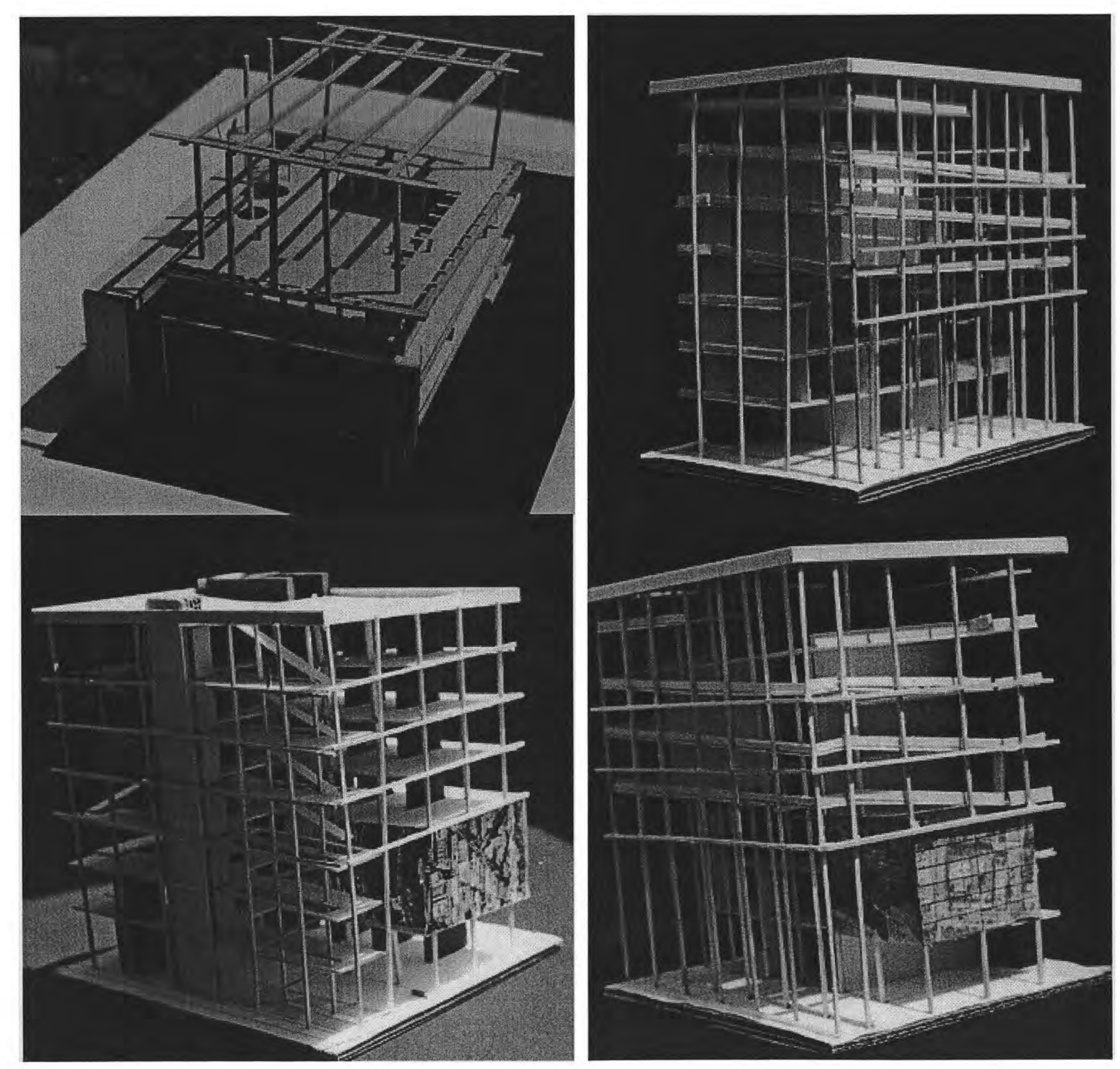

Fig 98 


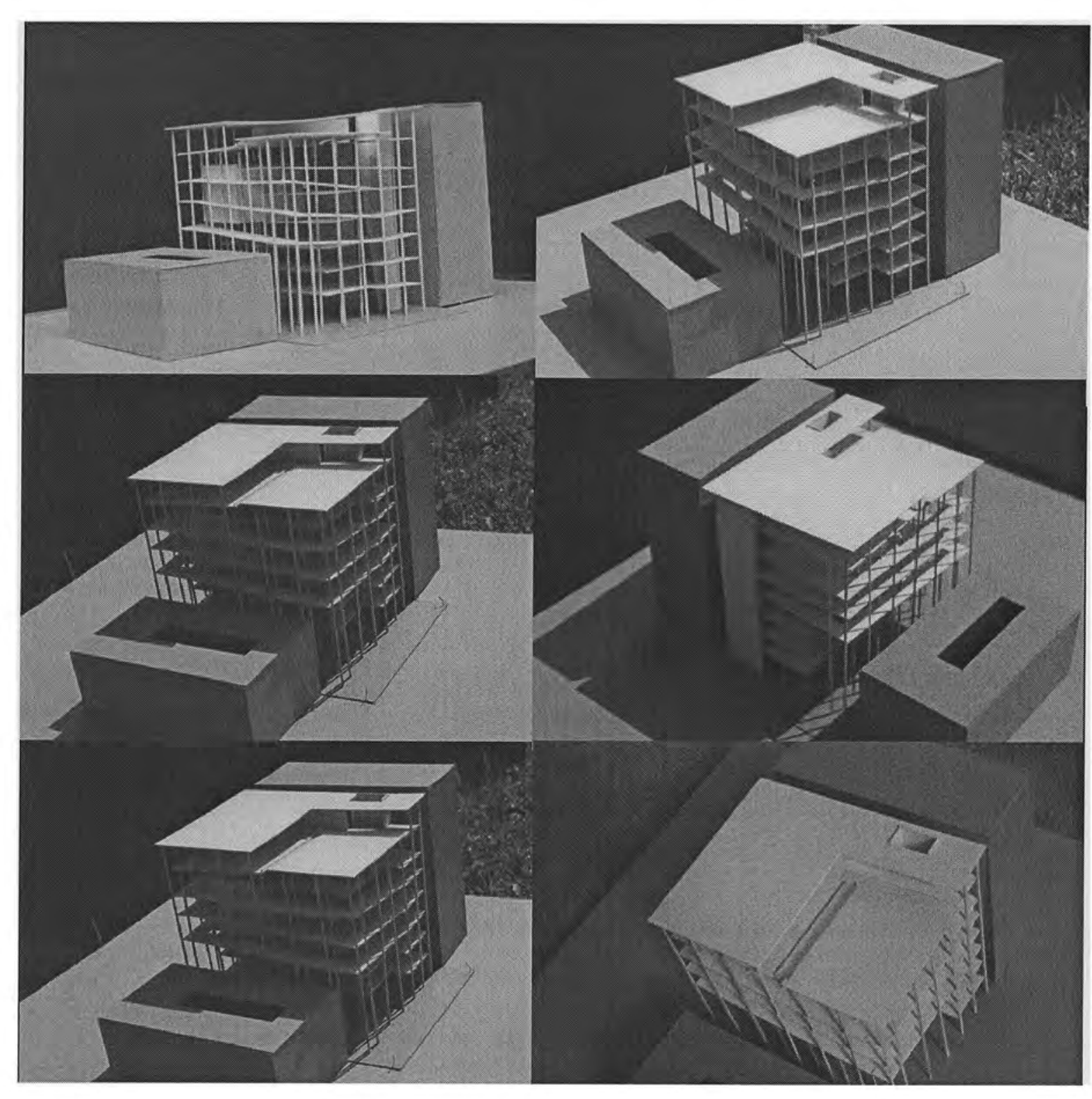

Fig 99

1 1. Fig 100 


\section{LIST OF REFERENCES}

\section{Books}

Allman, T.D. Miami La Ciudad del Futuro. Miami, Florida: D.L.E. Publishing House, 1988

Brand, Stewart. How Buildings Learn. England: Penguin Books Ltd., 1994.

Bland, Sidney R. Preserving Charleston's Past, Shaping Its Future. Westport,

Connecticut: Greenwood Press, 1994

Beard, Rick. Greenwich Village. New York: Rutgers University Press, 1993.

Capitman, Barbara. Deco Delights. New York: E.P. Dutton, 1988.

Capitman, Barbara. Rediscovering Art Deco U.S.A. New York: Penguin Books, 1994.

Cerwinske, Laura. Tropical Deco. New York: Rizzoli International Publications, Inc., 1981.

Chitty, Gill. Managing Historic Sites and Buildings. London: Routledge Press, 1999.

City of Miami Beach Economic Development Department. The City of Miami Beach Comprehensive Plan. 1980

City of Miami Beach Planning, Design and Historic Preservation Division. Ocean Beach Historic District Designation Report 1995.

Fitch, James, M. Historic Preservation.

Jacobs, Jane. The death and Life of Great American Cities. New York: Rondon House, 1961.

Joy, Deborah. Florida's Sandy Beaches-An Access Guide. Florida: Florida International University Press, 1985.

Kellerman, Regina. The Architecture of The Greenwich Village Waterfront. New York: New York University Press, 11989.

Lampugnani, Vittorio, M. Museums for a New Millenium. London: 1999.

McGovern, Bernie. Florida Almanac 1997-1998. Gretna Louisiana: Pelican Publishing Company, 1997-1998.

Miami Design Prservation League.MDPL Miami Beach Art Deco Guide. Miami Design Preservation League, 1987.

Miller, Terry. Greenwich Village and how it got that way. New York: Crown Publishers. Inc., 1990.

Moore, Arva. Magic City, Miami. Miami, Florida: Centennial Press, 1991.
Murtagh, William, J. Keeping Time. New York: Preservation Press, 1997.

Newhouse, Victoria. Towards a New Museum. New York: Monacelli Press, 1998.

Papadakis, Andreas, C. New Museums. London: Academy Group Ltd, 1991

Patricios, Nicholas, N. Building Marvelous Miami. Miami, Florida: University Press of Florida, 1994.

Shulman, Allan. Ciudad CityBabilonia. Colegio Oficial de Arquitectos Vasco-Navarro, 2000.

Raley, Michael. Old Miami Beach. Miami Beach, Florida: Miami Design Preservation League, 1994.

Rodriguez, Ivan A. From Wilderness to Metropolis. The History and Architecture of Dade County, Florida 1825-1940. Miami, Florida: Metropolitan Dade County, 1982.

Root, Keith. Miami Beach Art Deco Guide. Miami Beach, Florida: Miami Design Preservation League, 1987.

Scheinbaum, David. Miami Beach. Miami,FL: Florida International University Press, 1990.

Sena. Guidelines for The Rehabilitation of Designed Historic. Michigan: UMI Dissertation Services, 1998.

Spivey, Ted R. Time's Stop in Savannah Conrad Aiken's Inner Journey. Macon, Georgia: Mercer University Press, 1997.

Stansell, Christine. American Moderns. New York: Metropolitan Books, 2000.

Tyler, Norman. Historic Preservation. New York: W. W. Norton \& Company, Inc., 2000.

\section{Websites}

\section{http://www.ci.miami-beach.fl.us/index.html}

http://www.haznet.org

Ocean Drive Magazine. (June 2000)

Miami New Times (May 18-24, 2000) 